University of Louisville

ThinkIR: The University of Louisville's Institutional Repository

Electronic Theses and Dissertations

$5-2012$

\title{
"The greatest evil that can befall us" : Unionism in antebellum era Kentucky, 1849-1861.
}

Curtis Lushawn Parmley 1975-

University of Louisville

Follow this and additional works at: https://ir.library.louisville.edu/etd

\section{Recommended Citation}

Parmley, Curtis Lushawn 1975-, "'"The greatest evil that can befall us" : Unionism in antebellum era Kentucky, 1849-1861." (2012). Electronic Theses and Dissertations. Paper 1096.

https://doi.org/10.18297/etd/1096

This Master's Thesis is brought to you for free and open access by ThinkIR: The University of Louisville's Institutional Repository. It has been accepted for inclusion in Electronic Theses and Dissertations by an authorized administrator of ThinkIR: The University of Louisville's Institutional Repository. This title appears here courtesy of the author, who has retained all other copyrights. For more information, please contact thinkir@louisville.edu. 
"THE GREATEST EVIL THAT CAN BEFALL US": UNIONISM IN ANTEBELLUM ERA KENTUCKY, 1849-1861

\author{
By \\ Curtis Lushawn Parmley \\ B.A., University of Louisville, 2008
}

\begin{abstract}
A Thesis
Submitted to the Faculty of the

College of Arts and Sciences of the University of Louisville

In Partial Fulfillment of the Requirements

for the Degree of
\end{abstract}

\title{
Master of Arts
}

\author{
Department of History \\ University of Louisville \\ Louisville, Kentucky
}

May 2012 
“THE GREATEST EVIL THAT CAN BEFALL US”: UNIONISM IN ANTEBELLUM ERA KENTUCKY, 1849-1861

By

Curtis Lushawn Parmley

B.A, University of Louisville, 2008

A Thesis Approved on

April 05, 2012

by the following Thesis Committee:

Thomas C. Mackey (Thesis Director)

Benjamin Harrison

Jasmine Farrier 


\section{DEDICATION}

This master's thesis is dedicated to all

those who offered encouragement through the years. 


\section{ACKNOWLEDGMENTS}

I would like to thank above all my major professor, Dr. Thomas C. Mackey, for his guidance and patience. It has been a pleasure and privilege to work under his direction since my time as an undergraduate. I have enjoyed our "little chats" through the years. I would also like to thank Dr. Benjamin Harrison of the History Department for his service on my master's thesis committee, his comments and questions at the defense are appreciated. I would also like to thank Dr. Jasmine Farrier of the Political Science

Department for agreeing to serve on my master's thesis committee, her comments and questions are appreciated as well. I also owe thanks to Dr. A. Glenn Crothers for his sharp editing of Chapter Two and his numerous research suggestions that I am sure enhanced that chapter immensely. 


\begin{abstract}
“THE GREATEST EVIL THAT CAN BEFALL US": UNIONISM IN ANTEBELLUM ERA KENTUCKY, 1849-1861

Curtis Lushawn Parmley
\end{abstract}

April 05, 2012

During the secession winter of 1860-61 the Commonwealth of Kentucky found itself caught in the middle of the great sectional controversy. With the Union's fate hanging in the balance Kentucky figured as a prominent player in the outcome of that conflict. While the Commonwealth of Kentucky featured strong social and cultural ties to the South, its economic ties ran to both sections. Further, a majority of the people of the Commonwealth of Kentucky shared a nationalist perspective rooted in the old line Whig political ideology that they had a constitutional right to hold property in persons which contributed to their pro-Union sentiment. In the end, Kentucky, an Upper South border slave state, remained loyal to the Union. This master's thesis examines the origins and development of Kentuckian's Unionist sentiment during the Antebellum era and addresses the question: Why did Kentucky, a border slave state, forgo secession and remain loyal to the Union? Although cultural, social, economic, and political factors contributed to Kentuckian's pro-Union sentiment, in the end, Whig ideology constituted the key factor in Kentucky's decision to remain loyal to the Union. 


\section{TABLE OF CONTENTS}

\section{PAGE}

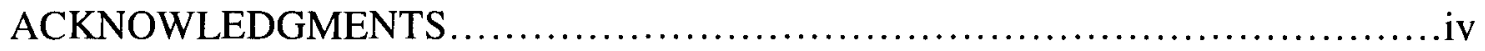

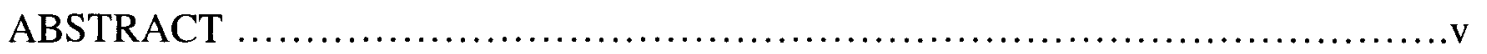

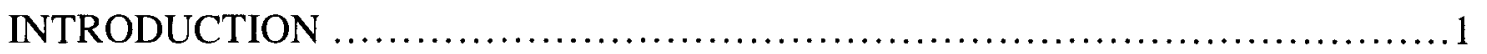

CHAPTER I: SLAVERY IN ANTEBELLUM KENTUCKY .........................13

CHAPTER II:

THE ANTISLAVERY MOVEMENT IN ANTEBELLUM KENTUCKY …...........38

CHAPTER III: WHIG IDEOLOGY AND KENTUCKY'S PROSLAVERY, PRO-

UNION STANCE IN THE ANTEBELLUM ERA .................................67

CHAPTER IV: KENTUCKY'S DILEMMA: THE POLITICS OF UNIONISM AND

SLAVERY IN THE ANTEBELLUM ERA ….................................... 88

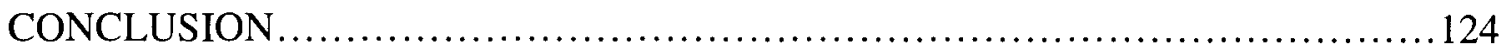

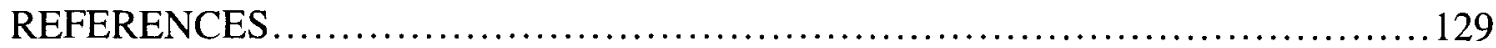

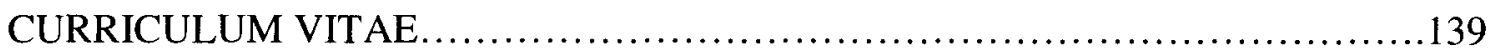




\section{INTRODUCTION}

\section{"THE GREATEST EVIL THAT CAN BEFALL US": UNIONISM IN ANTEBELLUM}

ERA KENTUCKY

This master's thesis examines the origins, development and persistence of Whig ideology in antebellum era Kentucky and considers its impact on shaping Kentuckian's pro-Union and proslavery responses to the secession crisis of $1860-61$. Specifically, this master's thesis addresses the question: Why did the Upper South border slave state Kentucky forgo secession and remain loyal to the Union? It concludes that although economic, social, cultural and geographic factors contributed to Kentucky's decision to forgo secession, in the end, Whig ideology served as the impetus that motivated Kentucky's decision to remain loyal to the Union.

Chapter One of this study examines the institution of slavery in Kentucky. Although Kentucky did not have a plantation economy dependent on slave labor, this chapter shows that slave labor formed a significant component of Kentucky's agricultural economy. Also this chapter examines the social and cultural ties that many Kentuckians had to the South and to the institution of slavery. The "herrenvolk democracy" of the Deep South, also existed in Kentucky. The attachment of social status to slaveholding was prevalent in Kentucky, particularly in the Bluegrass Region of the Commonwealth and resembled the aristocratic lifestyles of the plantation South. Many Kentuckians also feared race war and they viewed the practice of slavery as an effective means of racial 
control. Finally, Chapter One determines how Kentuckians conceptualized slavery in their state, either as a positive good or as a necessary evil. In the final analysis, a majority of Kentuckians believed slavery held a practical significance for their state.

Chapter Two examines the antislavery movement that existed and persisted in Kentucky for decades throughout the antebellum era. The state's antislavery politicians opposed slavery on political and economic grounds and they advocated for compensated gradual emancipation schemes often coupled with colonization. Abolition activists existed within the Commonwealth and they opposed slavery on moral grounds. The fact that a significant minority of Kentuckians held antislavery views suggests that most Kentuckians remained open minded enough to question slavery's practical significance for their state. As a result, a genuine slavery debate could and did occur within Kentucky. In the end, the antislavery movement did not succeed in eradicating slavery from the Commonwealth, but it did agitate for the antislavery agenda and the movement kept the slavery debate alive for decades within the Commonwealth.

Chapter Three examines the origins and development of Whig ideology that prevailed in Kentucky for decades throughout the Antebellum era. This chapter considers the significant role the state's prominent politicians like Henry Clay and John J. Crittenden played in developing the Whig ideology in the state. Their nationalist perspective in times of sectional crisis sought compromise first in an effort to preserve the Union. Inherent within this ideology prevailed a strong state's rights sentiment that contributed to Kentucky's mistaken belief that the institution of slavery could be maintained within the state while at the same time preserving the Union. 
Chapter Four examines the political developments in Kentucky during the crucial period from the state's third Constitutional Convention of 1849-50 through the state convention in 1861 that voted to keep Kentucky in the Union. Upon examining the state's political actions during this time period it becomes clear that Whig ideology possessed a strong hold on a majority of Kentuckian's proslavery and pro-Union supporters. This chapter examines the outcome of the state's third Constitutional Convention of 1849-50 that bolstered slavery in the state. Next, this chapter analyzes the state's federal elections in 1858 and 1860 and concludes that the pro-Union majority sentiment in Kentucky is expressed in the outcome of the 1860 congressional election. This chapter also assesses the state's neutrality policy in 1861 and shows that despite the effort to remain neutral and avoid conflict that in the end it proved erroneous. In time, the state's political leaders realized the best way to protect slavery within their state was to remain loyal to and fight to preserve the Union. This chapter concludes that Kentuckians' proslavery and proUnion sentiment was rooted in their pre-war Whig political ideology.

During the secession winter of 1860-1861 Kentuckians found themselves in the middle of the great sectional controversy. The question whether to maintain the Union or allow the slaveholding southern states to secede from the Union was imminent and demanded immediate attention and action. Following the November 1860 election of Republican and Kentucky's native son Abraham Lincoln to the presidency of the United States, the free labor North and slave power South reached an impasse that proved to difficult to resolve through conciliatory compromise efforts. As the southern slave states began to secede, Kentucky's loyalty to the Union remained in question. Both sections understood the key role the border slave state Kentucky would play in any sectional 
conflict. ${ }^{1}$ The border slave state Kentucky served as the geographic divide between the two sections. Kentucky's political, economic, geographic and military importance to the competing sections cannot be overstated. Thus, the interest the Commonwealth received from the competing sections can be understood. Both sides had much to gain by gaining Kentucky's support for their cause and perhaps, better stated, even more to lose by failing to maintain or gain Kentucky's loyalty during the conflict.

The desire by a majority of Kentucky's legislators to safeguard slavery served to influence their decision to first adopt a neutrality policy and later maintain loyalty to the Union. Proslavery Kentuckians believed their right to own slaves was best protected inside of the Union, under the United States Constitution rather than outside of it. Despite Kentuckians strong belief in their right to own slaves the state's politicians, particularly Henry Clay, himself a slave holder, sought first to maintain the Union when the slave question presented itself on the national political scene.

In 1820, Henry Clay crafted the Missouri Compromise and in 1850 influenced John J. Crittenden to craft the Compromise of 1850 . In both cases, Clay and Crittenden worked to appease the contending sections and avert a civil war. Following the presidential election of 1860 Senator Crittenden made one more desperate effort to bring the competing sections together with yet another compromise proposal. That effort made significant concessions to the slaveholding South as the proposal, introduced by Crittenden on the floor of the United States Senate on December 18, 1860, called for the extension of slavery into the federal territories. Thus, the Republicans rejected the

\footnotetext{
'For a good discussion and analysis of Kentucky's importance during the conflict see, Thomas C. Mackey, "Not a Pariah, but a Keystone: Kentucky and Secession," in Sister States, Enemy States: The Civil War in Kentucky and Tennessee, eds. Kent T. Dollar, Larry H. Whiteaker, and W. Calvin Dickinson (Lexington: The University Press of Kentucky, 2009), 25-45.
} 
measure outright as it violated the basic tenet on which their Party platform rested. ${ }^{2}$ Despite the fact that a majority of Kentuckians defended their right to own property in persons under both, state and federal constitutions, the politicians within the Commonwealth had supported measures to preserve the Union on many past occasions that spanned decades.

While it is true that over the years Kentucky's federal legislators along with their northern counterparts made many concessions to the proslavery South's demands in an attempt to reach compromise agreements, in fact, these bold efforts required positive actions and offered practical solutions that undermined secession and achieved their ultimate goal of preserving the Union.

Therefore, it may seem contradictory that a majority of Kentuckians advocated for and defended their right to own slaves while at the same time worked to maintain the Union. Defending a Union that tolerated slavery, however, was a different objective than preserving a Union that sought to eradicate it. Kentucky had managed to perform a balancing act to meet its own self-interest in each of these negotiations. During the secession crisis of 1860-61, Kentucky state legislators endorsed Governor Beriah Magoffin's neutrality policy that in the beginning seemed like the logical move for the politicians within the state, who sought to maintain the state's economic interests and avoid conflict, while at the same time continuing the practice of slavery within the state. In the end, the Commonwealth of Kentucky's neutrality policy proved impractical. It was not possible for Kentucky to remain neutral in a sectional conflict that posed threats to the public peace within the state. A majority of the people of the Commonwealth of

\footnotetext{
${ }^{2}$ Albert D. Kirwan, John J. Crittenden: The Struggle for the Union (Lexington: University of Kentucky Press, 1962) 375-382.
} 
Kentucky believed in a constitutional right to hold property in persons was best maintained inside the Union.

One must also consider the Commonwealth's economic ties to gain a clearer understanding as to why Kentucky chose to remain loyal to the Union. Thanks to its geographic positioning between the north and south, Kentucky had economic ties to both sections. Kentucky's navigable waterways proved instrumental to its trade with both sections. The states' entire northern border is the Ohio River and its western border is the "father of waters" the Mississippi River. The Cumberland and Tennessee Rivers also proved significant in establishing trade routes as those waterways meander through the state and provided access deep into the South, through Tennessee and into Alabama, in the case of the Tennessee River and empties into the Ohio near the Mississippi. The Cumberland River flowed down from the northeast, snaking its way along the states southern border with Tennessee, into the western part of the state before heading southward for Nashville and finally turning back northward into Kentucky before emptying into the Ohio, again close to where it flows into the Mississippi. Thus, goods throughout the state could be transported to distant markets like Nashville, Memphis, and New Orleans, and then via the same route back to the northeast United States via the Gulf of Mexico and the Atlantic. Markets like Cincinnati and Louisville were easily accessible as well, and with the development of the railway lines, goods could be transported from these cities throughout the North. The waterway systems, railway lines and its geography enhanced Kentucky's commerce of its rich natural resources, agriculture goods and manufacturing products. Kentucky's central location allowed it to develop trade relations with both sections and provided linkages that in the end proved 
difficult to break and, in fact, contributed to Kentucky's illusory neutrality policy during the secession crisis.

Social, cultural, and economic factors contributed to a majority of Kentuckians proslavery and pro-Union stance in response to the secession crisis. Strong social and cultural ties to the South and to the institution of slavery bolstered their proslavery stance. The so called "herrenvolk democracy" that existed throughout the South was present in Kentucky as well. Slaveholders achieved an elevated social status in the larger community that provided an impetus for them to resist losing their slaves. Nonslaveholders also could aspire to attain slaves that would afford them a higher social standing within the larger collectivity.

Most Kentuckians also could not envision a society with multitudes of freed peoples living among them. Like many people throughout the South, Kentuckians feared race war and pointed to slavery as an effective means of racial control. Slaveholders also pointed to the substantial economic losses they would suffer if slavery was eradicated in their state. Therefore, many factors contributed to a majority of Kentuckians support for protecting slavery within the Commonwealth that, in turn lent itself to their adopting a pro-Union stance in response to the secession crisis.

A significant minority of people in the Commonwealth espoused an antislavery sentiment. Most antislavery supporters in Kentucky opposed slavery on political and economic grounds and advocated gradual compensated emancipation of slaves, often coupled with colonization. Among the state's antislavery political actors Henry Clay, Robert J. Breckinridge and Cassius Clay were the most prominent. In addition to the conservative gradual emancipationists, a small contingent of abolitionist activists also 
lived within the Commonwealth. The abolitionists in Kentucky opposed slavery on moral grounds and worked to achieve full eradication of slavery within Kentucky.

Abolition activists such as John G. Fee, James G. Birney, Delia Webster, Calvin Fairbank and former slaves like Henry Bibb all made efforts to eradicate slavery from the state. In the end, the antislavery movement in Kentucky was unsuccessful; however, the efforts on the part of the antislavery activists within the state kept slavery agitation alive in the Commonwealth.

Since achieving statehood in 1792, Kentucky had favored a strong state's rights view as evidenced by the Commonwealth's first state constitution. Six years later the Kentucky legislature endorsed the Kentucky Resolutions of 1798 and 1799 that upheld the right of a state to secede from the federal government if it had become unacceptable and expounded that it was a crime to coerce a state to remain in the Union. ${ }^{3}$ Later, however, Kentucky Whig Senator Henry Clay synthesized this states' rights policy in sentiment at least, with a strong nationalist perspective.

This old line Whig's nationalist view developed in part due to economic considerations. Clay supported the idea of developing a national infrastructure to facilitate the nation's economic expansion. Beginning in the early 1800 s, but especially by the late 1820 s, the nation's economy grew. Technological innovations at the turn of the century, like the cotton gin, and steam power, and later communications advancements like the telegraph, as well as, the development of transportation networks like canals and railroads, all contributed to the development of the nation's economy as well as, to western migration into the federal territories. Henry Clay's Whig Party proved

\footnotetext{
${ }^{3}$ The Kentucky Resolutions of 1798 and 1799 in, Lewis and Richard H. Collins, Collins' Historical Sketches of Kentucky: History of Kentucky, Volume I (Louisville: John P. Morton \& Company Inc., 1924).
} 
staunch advocates for national internal improvements to facilitate the nation's economic expansion. Clay's American System advocated federal policies in economic matters like supporting a United States Bank, implementing protective tariffs on imports to protect domestic manufactures, and decrease dependence on foreign trade. This nationalist economic perspective lent itself to a nationalist political perspective that he utilized time and again in an effort to maintain the Union.

Henry Clay recognized his state's delicate, yet strategic geographic and political position in national affairs. He understood how to achieve a balance between the nation's two sections in times of political crisis. As the western migration continued the question of whether to allow slavery to extend into the federal territories arose and persisted for decades. Henry Clay figured prominently in each of the slavery debates from the Missouri Compromise of 1820, to the Wilmot Proviso of 1848 and the Compromise of 1850. ${ }^{4}$ Under Henry Clay's leadership the nationalist Whig Party dominated Kentucky politics for over forty years. ${ }^{5}$ His influence shaped policy in Kentucky for years following his death. Henry Clay's persistent struggles to hold the Union together earned him the reputation as the Great Compromiser. Clay's nationalist influence proved to have a lasting impact on Kentucky's politicians and their politics throughout the 1850 s and into the secession winter of 1860-1861.

In 1850 , the threat of secession arose once again. Kentucky's politicians sought compromise efforts aimed at conciliation, in an effort to maintain the Union. Senator John J. Crittenden followed Henry Clay's compromise tradition and crafted the

\footnotetext{
${ }^{4}$ William W. Freehling, The Road to Disunion. Volume I. Secessionists at Bay, 1776-1854 (New York: Oxford University Press, 1990).

${ }^{5}$ Robert V. Remini, Henry Clay: Statesman for the Union (New York: Norton, 1991). For the most complete history of the Whig Party see, Michael F. Holt, The Rise and Fall of the American Whig Party: Jacksonian Politics and the Onset of the Civil War (New York: Oxford University Press, 1999).
} 
Compromise of 1850 to appease both sections --especially the slaveholding South-- in an effort to avert a sectional conflict. Following the election of 1860 Crittenden renewed his efforts to reach compromise between the contentious sections, once again in an effort to undermine secession, maintain the Union and avert civil war. Kentucky again found itself caught in the middle of the sectional controversy and since 1820 had always sought first to preserve the Union. In the end, the old Whig political ideology first promoted by Henry Clay and continued by John J. Crittenden and others after his death proved critical in shaping the Unionist sentiment that prevailed over a state's rights view in Kentucky from 1850 through 1861.

It is also necessary to assess the power of ideology and its influence on the state's politicians. Perception influences understanding. A distorted perception of reality, lends itself to an erroneous view of any particular situation; thus, leading to erroneous actions. Some historians link Kentuckians' illusion of neutrality to their unwillingness or inability to recognize that the Union under the leadership of Abraham Lincoln would not, or in fact, could not remain intact as it was prior to his election. The proslavery South secession undermined any chance at reconciliation between the two sections which in turn, proved to be the death knell of the "Union as it was." Thus, it was likewise not possible for the Constitution that sanctioned the right to hold property in persons, "the Constitution as it is," ${ }^{7}$ to remain intact. The contending sections had reached an impasse. Their competing views regarding slavery and its expansion distorted their views of each other. Kentuckians sought to reconcile these irreconcilable differences in a conciliatory manner in an effort to appease both sections. The pro-secession South's ideological

\footnotetext{
${ }^{6}$ Louisville Journal, April 17, 1861.

${ }^{7}$ Ibid.
} 
conceptions were rooted in a strong state's rights theory that allowed state's through their sovereignty the right to rebel; thereby, resisting coercion from the North in an effort to continue their slave labor system and protect their way of life. Both sections refused to yield to the other and both sections cited their own competing ideological moorings as a means of defending their respective labor systems. The same was true for Kentucky; however, its situation is more complex owing in part to its geographic location but more importantly to the divergent ideological views its citizens held. Many Kentuckians clung to the state's rights view and supported secession. Many others shared the same state's rights philosophy, but were strong Unionists. This latter group's views proved more complex. On the surface, it seems erroneous for the majority of the people of a slave state to expound a political theory that held to a state's rights sentiment, but also advocated preservation of the Union.

In the 1850's the issue of slavery's expansion into the federal territories was at the forefront of the political agenda for both sections and resolution only occurred through military conflict. Thus, Kentucky's policy of neutrality may have been rooted in a distorted view of its own reality within the apparent conflict. It may have likewise been naïve for Kentucky to assume that it could continue its economic relations with both sections without one or the other imposing some mechanism of restraint in an effort to gain the Commonwealth's loyalty. From a political perspective, Kentucky's neutrality policy was a practical measure enacted by Kentucky's legislature to appease both sections. This illusory and ambiguous neutrality policy reflected the complex views held by a majority of the people of the Commonwealth. Kentucky's social and cultural ties as well as its state sanctioned institution of slavery all contributed to Kentucky's complex 
and conciliatory approach to attempt to resolve the sectional conflict. The state's nationalist outlook was an outgrowth of the influence of Whig ideology. The "peculiar institution" of slavery proved to be the wedge driven down the middle of Kentucky's political philosophy. Thus, Kentucky's ambiguous neutrality policy was an outgrowth of its complex ideology that reflected the border slave state's response to the many and often competing dynamics, whether political, economic, geographic, or even social and cultural that operated on it. Therefore, Kentucky did not respond to the events of the secession winter due to its distorted perception of its own reality; rather, it responded to those events based on the complex nature of its reality. Thus, it can be ascertained Kentucky's response reflected the majority will of its constituency regarding its neutrality policy. While the neutrality policy failed, it did represent the state legislature's best effort to craft a policy measure that above all served its majority interests consistent with their long-standing Whig ideology. 


\section{CHAPTER I}

\section{SLAVERY IN ANTEBELLUM KENTUCKY}

Since it became a state in 1792 and throughout the antebellum era, Kentucky law sanctioned slavery. A majority of white Kentuckians also supported slavery and continued to do so through the Civil War, even though a majority of Kentuckians supported the Union. Despite the war's outcome many Kentuckians clung to the notion that they had a right to hold property in persons; therefore, it is not surprising that Kentucky refused to ratify the 1865 Thirteenth Amendment to the United States Constitution. In the end, the upper south border slave state Kentucky was caught between its proslavery stance and its unflinching support for the Union. Although Kentuckians were nationalist in their outlook, economically, politically, and perhaps to a lesser extent socially, they were reluctant to undergo drastic change regarding race relations. Kentuckians rooted their unwillingness to end the peculiar institution in part in its cultural heritage. Large slaveholders attained a high social standing among the community and many non-slaveholding whites thus, aspired to acquire slaves as well. ${ }^{1}$ Many clung to their belief in state sovereignty and their state constitutional right to hold chattel property. ${ }^{2}$ In addition, Kentuckians viewed slavery as a mechanism to control the

\footnotetext{
' J. Winston Coleman, Jr., Slavery Times in Kentucky (Chapel Hill, N.C.: The University of North Carolina Press, 1940, 21-26.

${ }^{2}$ For a complete analysis of Kentuckian's belief in their constitutional right to hold property in persons see chapter 4 of this work, "Kentucky's Dilemma: The Politics of Unionism and Slavery in the Antebellum Era." E. Merton Coulter, The Civil War and Readjustment in Kentucky (Chapel Hill,N.C.: The University of North Carolina Press, 1926), 7.
} 
black race. ${ }^{3}$ In certain parts of the state slave labor proved more profitable than in others, and the slave trade proved quite lucrative for many within the state. ${ }^{4}$ In Antebellum Kentucky cultural, social, legal, and to varying degrees economic considerations contributed to a strong proslavery sentiment among the majority of Kentuckians. This chapter analyzes the impact each of these contributing factors had on the practice of slavery within the state. In addition, this chapter provides a brief demography of slavery within the state from its earliest days of settlement through 1860 in order to set slavery in Kentucky in its historical context and to provide a clear picture of slavery's significance throughout the state.

Slavery existed in Kentucky since its earliest days of settlement. In 1751, a slave accompanied Christopher Gist as he explored the region that bordered the Ohio River, near the Falls of the Ohio. ${ }^{5}$ A slave served as a guide for Daniel Boone in 1760, as he journeyed down the Wilderness Road across the Cumberland Gap into southeast Kentucky. ${ }^{6}$ In 1775 Boone brought more settlers into Kentucky which included several slaves. $^{7}$ By the 1780 's thousands of farmers migrated west, into the Kentucky frontier from Virginia, Pennsylvania, North Carolina, Maryland and New York. Many of these farmers were slaveholders and the black population on the Kentucky frontier grew exponentially during the 1780's. According to some accounts so many settlers and their

\footnotetext{
${ }^{3}$ Harold D. Tallant, Evil Necessity: Slavery and Political Culture in Antebellum Kentucky (The University Press of Kentucky, 2003), 7.

${ }^{4}$ Lowell H. Harrison and James C. Klotter, eds., A New History of Kentucky (Lexington: The University Press of Kentucky, 1997), 167-68.

${ }^{5}$ William M. Darlington, ed., Christopher Gist's Journals (Pittsburgh, 1893), 31, 43-44, 58.

${ }^{6}$ John Bakeless, Master of the Wilderness, Daniel Boone (New York, 1939), 32, 66-72; Otis K. Rice, Frontier Kentucky (Lexington, 1975), 59-60; Marion B. Lucas, A History of Blacks in Kentucky: Volume I, From Slavery to Segregation, 1760-1891 (Frankfort: The Kentucky Historical Society, 1992), xi; see also, J. Winston Coleman, Jr., Slavery Times in Kentucky (Chapel Hill, N.C.: The University of North Carolina Press, 1940), 4.

${ }^{7}$ Bakeless, Boone, 90-91. George W. Ranck, Boonesborough (Louisville, 1901), 10-11, 161-164. See also, Thomas Speed, The Wilderness Road, (Louisville, 1886) 31-32.
} 
slaves migrated to the Kentucky frontier that in some areas frontier conditions in the wilderness ceased to exist by $1790 .^{8}$

According to the first United States Census in 1790, 11,830 slaves and 114 freemen lived on the Kentucky frontier, accounting for sixteen percent of the state's entire population. By the turn of the century, according to the 1800 United States Census, blacks represented nineteen percent of the total population and had increased to 41,084 . The number of freemen also increased during this same period, from 114 in 1790 to 741 in $1800 .^{9}$ After achieving statehood in 1792 , Kentucky's black population continued to increase by two percent per decade through 1830 , when the total black population in the state reached 165,213 slaves and 4,917 freemen, representing 24.7 percent of the total population in the state. ${ }^{10}$ In the first forty years after achieving statehood, Kentucky's black population growth rate increased greater than the white population. By 1830 , there was one black person for every three white people in the state. ${ }^{11}$ By 1850 , however, the black population relative to whites had declined. ${ }^{12}$ This slow, but steady decline can be attributed to several factors, such as, the nature of Kentucky's agricultural system that consisted of mainly, small farms that did not demand large numbers of slaves for labor. Also, the 1833 Kentucky Non-Importation Law that made it illegal to import slaves into Kentucky for resale, and the ever increasing, and lucrative business of slave trading with the Deep South states, all contributed to the decline in the black population within the

\footnotetext{
${ }^{8}$ Ivan E. McDougle, Slavery in Kentucky, 1792-1865 (Lancaster, Pa., 1918), 4.

${ }^{9}$ United States, Second Census of the United States, 1800 (Washington, D.C., 1801), 2. See also, Joan Wells Coward, Kentucky in the New Republic: The Process of Constitution Making (Lexington. Ky,: The University Press of Kentucky, 1979), 37, 63.

${ }^{10}$ United States, Second Census of the United States, 1800 (Washington D.C, 1801), 2.

${ }^{11}$ Lowell H. Harrison, The Antislavery Movement in Kentucky (Lexington, Ky: The University Press of Kentucky, 1978), 2-3; see also McDougle, Slavery, 9-10.

${ }^{12}$ United States, Seventh Census of the United States, 1850 (Washington, D.C., 1853 ), 615.
} 
state. ${ }^{13}$ By 1860 , Kentucky's black population represented twenty percent of the total population, with 236,167 blacks living within the state. ${ }^{14}$

While slavery in Kentucky was never as prevalent as it was in the Deep South states, the peculiar institution was still significant in the Commonwealth. Kentucky's topography, climate, small scale farms, and diversified economy limited the necessity of slavery in the state relative to the states in the Deep South where large plantations and milder temperatures and longer growing seasons all contributed to a greater demand for slave labor. However, in 1860 Kentucky ranked third only behind Virginia and Georgia for the most slaveholders with $38,645 .^{15}$ Kentucky also ranked third behind Virginia and Georgia for the most slaveholders who owned between one and seven slaves. ${ }^{16}$ Kentucky ranked ninth for the total number of slaves. Out of nearly 39,000 total slaveholders in the state only seventy owned more than fifty slaves; while just seven slaveholders owned more than one hundred slaves and no slaveholders in Kentucky owned more than three hundred slaves. ${ }^{17}$ These numbers suggests the small scale agriculture that dominated the state required less demand for slave labor than the large plantations found throughout the South. In addition, these figures show that many people in Kentucky were slaveholders, and thus, slavery was not confined only to the upper elites in society; but, slavery was distributed among many landowners that included small scale farmers within the state. In fact, according to the Frankfort Commonwealth, "All that are able to own slaves in Kentucky are not already slave owners. There are more men able to own slaves in

\footnotetext{
${ }^{13}$ Lucas, A History of Blacks in Kentucky, $x v$.

${ }^{14}$ Seventh Census, 1850, 615.

${ }^{15}$ United States, Eighth Census of the United States, Agriculture, 1860, 247.

${ }^{16}$ Eighth Census, Population, 1860, 599.

${ }^{17}$ Ibid., Agriculture, 247.
} 
Kentucky who do not own them, than there are slaveholders."18 Thus, Kentuckians practiced slavery more for practical necessity than mere stature. ${ }^{19}$ However, for others there was a social status attached to owning slaves.

The eastern quarter of the state consists of the Appalachian Mountains. That mountainous and hilly terrain with steep slopes, narrow valleys and infertile soils was never well suited to farming on any meaningful scale. Thus, new farmers into the state continued their westward migration into the state's interior Bluegrass Region where lush rolling hills and meadows with rich soils are abundant. That area was home to more slaves than any other region in the state. The Bluegrass Region consists of thirty seven counties that cover eight thousand square miles. ${ }^{20}$ In 1860 , Woodford County boasted the largest percentage of blacks with just fewer than fifty three percent of its population living within its borders. Seven other counties in the Bluegrass Region had black populations of more than forty percent and seven other counties had black populations of over thirty percent. In 1860 , according to the United States Census the western region of the state also consisted of thirty seven counties. None of those counties had black populations of more than half their total population. Logan and Todd counties, located along the state border with Tennessee in the southwest section of the state had black populations that were more than forty percent of their total and four other counties in this region had over thirty percent blacks living within their counties' borders. Seven counties made up the Jackson Purchase Region in the far western reaches of the state,

\footnotetext{
${ }^{18}$ Frankfort Commonwealth, March 10, 1857.

${ }^{19}$ For the most thorough explication of the "evil necessity" theory, see, Harold D. Tallant, Evil Necessity: Slavery and Political Culture in Antebellum Kentucky (Lexington: The University Press of Kentucky, 2003).

${ }^{20}$ Lucas, A History of Blacks in Kentucky, xvii. See also, Thomas D. Clark, A History of Kentucky (New York, 1937), 3-4.
} 
where Ballard and Fulton counties shared the largest percentage of blacks with twenty percent each. The Mountain counties in the eastern portion of the state consisted of twenty eight counties and had few slaves relative to the other regions. Johnson County had the lowest percentage of blacks living within its borders in the Mountain Region and the entire state at less than one percent. Wayne County located in the south central portion of the state, with its eastern section consisting of spiny ridges that are the foothills of the Appalachian Mountains and its western half consisting of rolling grass laden meadows with rich soils reminiscent to those found in the Bluegrass Region had the largest percentage of blacks living within her borders in 1860 at just under ten percent. ${ }^{21}$

Throughout Kentucky, larger concentrations of the black population could be found in towns and cities than in the country side, suggesting that many slaves were hired as laborers to perform work as personal servants or skilled trades. ${ }^{22}$ Located along the Ohio River in the western section of the state, the city of Henderson, boasted a black population of nearly half of the city's 1,775 inhabitants. Located near Henderson, along the Ohio River, Owensboro the region's largest city had a black population of forty nine percent in 1830 , but, by 1860 , had declined to twenty eight percent of the city's total 2,308 residents. Located in the southwestern portion of the state, near the Tennessee border, Hopkinsville was one of the areas largest towns and in 1860 slightly more than half its residents were black. The Bluegrass Region's largest city, Lexington, had a black population of forty one percent of its total in 1840. By 1860, Lexington's black

\footnotetext{
${ }^{21}$ Ibid., Lucas, prologue, figure 2. See also, Richard L. Troutman, "The Social and Economic Structure of Kentucky Agriculture, 1850-1860" (PhD. Dissertation, University of Kentucky, 1958), 15; Arthur C. McFarlan, Geology of Kentucky (Lexington: The University of Kentucky Press, 1943), 185-186, 203; Clark, Kentucky, 6-7.

${ }^{22}$ Ibid., Lucas, xvii-xviii.
} 
population had declined to roughly one third of its total population, or 3,080 blacks among 9,521 people altogether.

In 1860 , the state's largest city, Louisville, had a black population of only ten percent of its total population, but the city boasted the state's largest urban concentration of blacks, with $6,820 .^{23}$ Almost all of the state's black population was slaves. However, free blacks lived within the state as well. In 1790, 114 free blacks resided in Kentucky, representing slightly less than one percent of the black population and only $0.2 \%$ of the total population. By 1860 , there were 10,684 free blacks living in the state, representing $4.52 \%$ of the black population and $0.9 \%$ of the total population. ${ }^{24}$ Black people lived throughout the state of Kentucky during the nineteenth century.

In 1860 , every Kentucky County had black people living within their borders. The number of blacks living in the state ranged from less than one percent of the total population in some mountain counties in the eastern section of the state to over fifty percent in other counties in the Bluegrass Region and in the south western part of the state. Although a few free blacks lived in Kentucky, between 1800 and 1860 the slave population in the state was never fewer than ninety five percent of the state's total black population. ${ }^{25}$ These demographics suggest the varied nature of the prevalence of slavery in the state, as well as the close contact that people throughout the state had with the institution. People from the mountainous eastern section of the state to the interior Bluegrass Region into the Jackson Purchase area in the western section of the commonwealth all, to some degree experienced slavery. Whether they were slaveholders

\footnotetext{
${ }^{23}$ See, United States Census, 1830, 1840, 1850, 1860. See also, Lucas, A History of Blacks in Kentucky, prologue.

${ }^{24}$ United States Census Reports, 1790-1860.

${ }^{25}$ Ibid.
} 
or non-slaveholders everyone in Kentucky viewed slavery firsthand. Thus, in Kentucky slavery was a living institution. The closeness of the people of the Commonwealth to the "peculiar institution" led a few to question its practical significance for their state. This closeness to slavery led many others, in fact, the majority of Kentuckians, to defend the institution, often citing slavery's practical effect for their Commonwealth.

In antebellum era Kentucky southern culture dominated its inhabitants. Kentucky's origins were in Virginia. The Commonwealth of Kentucky had belonged to the "Old Dominion" and was subject to its legislature for seventeen years after Virginia achieved statehood. Many Virginians migrated into Kentucky after it was admitted into the Union. Located along the border with Virginia in the southeastern corner of the state, the Cumberland Gap served as the main route west for Virginians as they traveled along the Wilderness Road. Many others from North and South Carolina traveled this same route into the state as well. A considerable number of settlers traveled down the Ohio River from the North, particularly from Pennsylvania; many of whom were of southern origins themselves, and also a significant number came from New York. ${ }^{26}$ By 1860 , however, the vast majority of new settlers into the state were of southern origin. According to the 1860 United States Census over 45,000 settlers had migrated into the state from Virginia, while an additional 34,000 had came from Tennessee. ${ }^{27}$ Therefore, the Commonwealth of Kentucky, from its earliest days had a strong southern influence.

During the nineteenth century a changing economy in Kentucky transformed the state from a pioneer wilderness into productive agriculture and commercial centers. The Bluegrass Region was particularly important in this development. Settlers cleared land to

\footnotetext{
${ }^{26}$ Harrison and Klotter, eds., A New History of Kentucky, 48-52. See also, Lucas, A History of Blacks in Kentucky, volume I, xiv. Coulter, The Civil War and Readjustment in Kentucky, 8.

${ }^{27}$ United States, Eighth Census of the United States, Population, I860, 185.
} 
take advantage of the rich natural resources and fertile soil. Many aristocratic settlers from outside the state, particularly from neighboring Virginia, began poured into the state, especially into the Bluegrass Region to reap the economic rewards. Francis Fedric, a slave from Virginia, who moved with his master to Kentucky, and later escaped to freedom recalled his experience, in his memoirs, writing, "When we arrived there ... [t]he first thing the negroes did was to clear the land of brush and then sow blue grass seed for the cattle to feed on. Then they fenced in the woods for what is called woodland pasture." Over time settlers cleared land, acquired additional slaves and built a home befitting the master and his family. ${ }^{28}$

Many other prominent families from Virginia, Pennsylvania and Maryland followed a similar course. Josiah Henson, a former slave from Maryland recalled his experience, writing, "the situation was in many respects more comfortable" than the conditions they had left behind in Maryland. Henson recalled, his master's Kentucky farm "was larger and more fertile, and there was a greater abundance of food, which is, of course, one of the principal sources of comfort of a slave."29 The comforts for the masters and their families proved to be an improvement as well. Settlers transformed the Bluegrass Region's countryside with elegant and stately brick homes and mansions, to accommodate the fast emerging well-to-do slaveholding planter class, replacing the old pioneer log cabins that had once dominated the landscape.

The landed gentry became more prominent in the state and their estates reflected their successes. In Jefferson County, near Louisville, John Speed, who owned seventy slaves,

\footnotetext{
${ }^{28}$ Francis Fedric, Slave Life in Virginia and Kentucky (London, 1863), 15-17.

${ }^{29}$ Josiah Henson, Father Henson's Story of His Own Life (Boston, 1858), 56.
} 
built an elegant estate along Beargrass Creek, named "Farmington." 30 William C. Bullitt, another prominent slaveholder, owned one thousand acres at his "Oxmoor" estate also located in Jefferson County. John C. Breckinridge a slaveholder, planter and politician owned "Cabell's Dale" located in Fayette County, just outside Lexington, where his over one hundred horses grazed the rich green pastures of the Bluegrass Region. Other prominent Kentucky families boasted large stately brick mansions situated on prime agriculture land in the Bluegrass, such as longtime statesman Henry Clay, whose "Ashland" estate was situated in Fayette County, just outside of Lexington. Henry Clay's relative, himself a noted politician within the state, Cassius Marcellus Clay owned an impressive estate called "White Hall" located in Madison County, not far from Richmond. Throughout the Bluegrass Region, the success of the slave owning planter class was evident by the stately mansions and estates that graced the countryside. ${ }^{31}$

The early economic successes of the planter class in Kentucky provided them with a sense of entitlement to enjoy an aristocratic lifestyle of leisure that had once been enjoyed by many of the settlers forebears in Virginia and also the Carolinas. This prevailing sentiment derived from the southern roots of the new Kentucky families. Throughout the South the planter class had grown accustomed to extravagant and leisurely lifestyles that manifested itself in their elegant brick mansions and estates, as well as, through their luxurious furnishings and dress. The men who occupied these grand estates had been referred to in Virginia as "gentlemen" and were viewed with reverence from fellow members of their communities. The southern culture that was so prevalent throughout

\footnotetext{
${ }^{30}$ James Speed, James Speed, A Personality, (Louisville, 1914), 4.

${ }^{31}$ See, John Melish, Travels through the United States, 1806-1811, II, (Philadelphia, 1815), 206. See also, Coleman, Slavery Times in Kentucky, 21-23.
} 
the South began to pervade the Kentucky countryside, particularly, in the Bluegrass Region of the state.

In 1826, Timothy Flint, a New Englander, who traveled through Kentucky noted that Kentuckians were"a high-minded people and possess the stamina of a noble character.. . . They generally are of one descent, and are scions from a noble stock-the descendants from affluent and respectable planters from Virginia and North Carolina." Flint continued, "There is a distinct and striking moral physiognomy to this people; an enthusiasm, a vivacity, and ardor of character, courage, frankness, generosity, that have been developed with the peculiar circumstances under which they have been placed. ..." Flint further observed, "They seem to feel that they have an hereditary claim to command, place and observance. This perfect repose of self confidence is in fact their good star. . ., 32

In 1845, one visitor wrote, "In points of comforts, of luxuries and even elegances, the Kentucky farmer compares well with the English, Irish or Scotch gentleman-farmer in every respect. Their houses generally speaking . . . are of brick; well and tastefully planned; large and roomy; and if any fault is to be found at all they are too magnificently furnished for a 'farmer's' residence." ${ }^{33}$ An article in the Niles' Weekly Register stated the farms near Lexington, "are well cultivated, and the farmers are generally rich and opulent, and many of them have coaches and carriages, made at Lexington, that cost one thousand dollars. ..."34 Elias P. Fordham, traveled to the state and noted, "A Kentucky planter ... has the manners of a gentleman; he is more or less refined according to his

\footnotetext{
${ }^{32}$ Timothy Flint, Recollections of the Last Ten Years, (Boston, 1826), 70.

${ }^{33}$ The Cultivator (Albany, New York), N.S., II, 373.

${ }^{34}$ Niles' Weekly Register, VII January 28, 1815), 339-40.
} 
education, but there is generally a grave, severe dignity of deportment in the men of middle age, which prepossesses and commands respect. ${ }^{35}$

In addition to the leisurely and often times lavish lifestyles led by many aristocratic families in the Bluegrass Region on the plantation, many of these affluent families also enjoyed the leisurely activities at any one of numerous resorts in the state. Kentucky's many springs provided an oasis and summer time retreat for many affluent Kentucky families as well as for wealthy families throughout the South. Olympian Springs, in Bath County, Graham Springs in Harrodsburg, Crab Orchard Springs in Lincoln County and Paroquet Springs in Bullitt County, were among the most well known and most visited resorts that rivaled any resorts found throughout the country and were often called the Saratoga of the South. ${ }^{36}$ The interaction among and between the elite southern families, that included much socializing, flirting and sometimes marriage, bolstered the strong sense of a "southern culture" within Kentucky. ${ }^{37}$

The institution of slavery provided the foundation for the development of a wealthy planter class, particularly, in the Bluegrass Region of the state. Slave labor afforded the large scale farmers in the state the opportunity to increase profits to a degree that afforded them a luxurious and exuberant life of leisure that mirrored the elite planter class of the plantation Lower South.

While the large scale slaveholders associated an elevated social status to slaveowning, many small scale farmers and wage earning laborers, or poor whites, likewise aspired to acquire slaves primarily for economic gain, but also to gain an elevated social

\footnotetext{
${ }^{35}$ Elias P. Fordham, Personal Narrative, (Cleveland, 1906), 216.

${ }^{36}$ Fortescue Cuming, Sketches of a Tour to the Western Country (Pittsburgh, 1810), 211-212.

${ }^{37}$ Coleman, Slavery Times in Kentucky, 40-41. See also, J. Winston Coleman, Jr., Stage-Coach Days in the Bluegrass, (Louisville, 1935), 183. Coulter, The Civil War and Readjustment in Kentucky, 8-9.
} 
status among the community. Even those poor whites who did not own, or perhaps even desire to become slaveholders; nonetheless, viewed slaves as inferior, thus affording themselves a higher social status that perhaps legitimized their sense of belonging in and contributions to the larger society. This line of reasoning posits white superiority over black slaves and is referred to by sociologist Pierre van den Berghe as "Herrenvolk Democracy." 38 The notion that whites belonged to a master race and were therefore, superior to those people who did not, permeated southern culture. ${ }^{39}$

The easiest way to draw distinctions among men was not only by their status as slaveholders, non-slaveholders or slaves, but simply by their race. A classification that ranked hierarchical status solely based on whether one owned slaves, not to mention the number of slaves owned, served to equate non-slaveholding whites with black slaves. Thus, to make it possible for non-slaveholding whites to enjoy a higher social status than black slaves, it became necessary to devise a social construct based on race. Pierre van den Berghe's concept of a "Herrenvolk Democracy" can be recognized in the Upper South border slave state Kentucky where many non-slaveholding whites lived, especially in the Appalachian Mountain region in the eastern third section of the state.

Thus, the transformation of Kentucky's countryside from a pioneer frontier land into a productive agricultural and to a lesser, but important extent, commercial center that relied to a significant degree on slave labor was well underway. By the 1850's Kentuckians understood that slavery was necessary for the continued success of the economy for the planter class and their leisure aristocratic lifestyle as well as for the success of many small scale farmers. The social status attached to owning slaves had gained significance

\footnotetext{
${ }^{38}$ Pierre van den Berghe, Race and Racism: A Comparative Perspective (New York, 1967).

${ }^{39}$ James M. Mcpherson, Ordeal by Fire: The Civil War and Reconstruction (New York: The McGraw-Hill Companies, Inc., 2001), 36-38.
} 
in Kentucky just as it had in the Carolinas and Virginia. Thus, the notion of a "Herrenvolk Democracy" that had been prominent throughout the plantation economies in the lower South had by the middle 1800's gained prominence in the Upper South border slave state of Kentucky. A majority of its white residents had adopted a "southern culture" mentality that equated social status with the number of slaves owned by a given slaveholder, or the number of slaves that a poor white may aspire to own someday. In either case, by the 1850's the attachment of a higher social status to slave owning was prevalent among Kentucky whites.

It was the logical extension of a society that supported a hierarchical structure based on race to also feel it necessary to implement forms of racial control. Much of that sentiment is derived from fears that the so-called inferior race poses a threat to the master race due to their desire to free themselves from their harsh economic and social conditions. Thus, the so called superior race felt the necessity to implement forms of social control over the perceived inferior races. Like most southerners many Kentuckians, pointed to the possibility of slave insurrection. Thus, they found it necessary to impose mechanisms of constraint over black slaves in an effort to thwart any slave rebellion. Occasional instances of violence on the part of slaves against their masters or other white people served to reinforce these fears. Amid white people's growing concerns, heightened measures were taken to oppose any perceived threat of resistance from slaves.

Proslavery proponents in Kentucky and throughout the South shared the sentiment that black slaves were inherently a debauched race of people whose moral principles and conduct was much inferior to their own. This assumption, placed the white race in a 
compromised moral position as they were forced to live among and control the black race. Whites believed living in close proximity to black slaves placed them in a compromised moral position and served as the basis for the necessary evil theory propounded by many proslavery advocates of the time. Many adopted the "necessary evil" theory to justify the idea that slavery was necessary to control the black race. ${ }^{40}$

A system based on a master and slave relationship was the only manner most whites could reconcile living among large numbers of black people. Slaves acted subservient to their white masters in exchange for having their basic needs met but also for fear of punishment meted out by their masters for disobedience. Many slaves realized they could not provide for themselves without their masters and in some cases even became loyal to their masters. Of course, slaves feared the punishment they might receive from their masters if they became disobedient or disloyal. Punishment depended on the masters themselves as well as for the offense committed but ranged from public scolding, to severe whippings with the lash, to brutal beatings or in extreme cases, death.

Nonetheless, Kentuckians thought slavery in their Commonwealth was milder than in the Cotton South states. Most Kentucky slave owners were small farmers and owned fewer slaves than their Deep South counterparts where the large plantations required large gangs of slaves to perform the necessary labor. Most Kentucky slaveholders owned five slaves or less. Also, most Kentucky slave holders worked along side their slaves performing the daily tasks necessary to operate their small farms. Many feel the close interaction between the masters and slaves in Kentucky improved the relationship between the two. Many historians concluded that Kentucky's geographic location that place it across the Ohio River from three Free states, Ohio, Indiana and Illinois served as

${ }^{40}$ See, Tallant, Evil Necessity, 10-11, 13, 17. McPherson, Ordeal by Fire, 51. 
the impetus for slave owners to treat their slaves better than they otherwise would have, for fear of their slaves escaping across the Ohio River and into freedom. According to this argument the slaves in Kentucky generally fared much better than their counterparts in the Deep South where the overall treatment of slaves was much worse. ${ }^{41}$

Early pro-Kentucky historians often compared the slavery system in Kentucky to the Deep South states and offered an interpretation that depicted the "peculiar institution" in the Commonwealth as a benign form of slavery that seemed to romanticize the institution. In 1922, William E. Connelley and E. Merton Coulter's series, History of Kentucky, analyzed the institution of slavery in Kentucky and concluded "the nature of the labor to be performed [by slaves] made their lot fairly easy." Ivan E. McDougle in his 1918 book, Slavery in Kentucky 1792-1865, argued that slavery in Kentucky was in fact, "a comparatively mild form of servitude." In his 1940 book, Slavery Times in Kentucky, J. Winston Coleman, Jr., offered a comprehensive study on the "peculiar institution" in the state and argued that slavery as it existed in Kentucky was "the mildest form that existed anywhere in the United States." 42

Kentucky law prohibited owners from abusing their slaves or treating them inhumanely. ${ }^{43}$ However, the law at the same time prescribed corporal punishment, in the form of public whippings, up to thirty nine lashes, for misdemeanor criminal offenses committed by slaves. Every Kentucky county had a whipping post located on the

\footnotetext{
${ }^{41}$ Eugene D. Genovese, Roll Jordan Roll: The World That Slaves Made (New York, 1972), 53-54.

${ }^{42}$ William Elsey Connelley and E. Merton Coulter, History of Kentucky, 5 vols. (Chicago and New York, 1922), 2: 797; Ivan E. McDougle, Slavery in Kentucky, 1792-1865 (Lancaster, Pa., 1918), 27, 93; Coleman, Slavery Times, 218.

${ }^{43}$ Kentucky Acts (1850-51), 1:297;
} 
courthouse lawn. Slaves convicted of misdemeanor crimes received the punishment of public flogging. ${ }^{44}$ But most discipline was immediate and informal.

Prosecutors rarely charged masters for mistreating their slaves, even fewer received punishment for abusing their enslaved people. In addition, to living in a subjugated state and being held as inferior to everyone in society, slaves in Kentucky endured much physical abuse at the hand of their masters. In addition to whipping other forms of punishment meted out by masters included branding their slaves. In 1848 the Louisville newspaper The Examiner published an article that made the public aware of a female runaway slave who according to the report, "is branded on the breast something like $\mathrm{L}$ blotched. ${ }^{45}$ Many of these types of descriptions can be found in newspapers throughout Kentucky. If slaves had attempted escape, masters would often place iron rings on slave's ankles or iron collars around their necks, sometimes with bells on them. ${ }^{46}$ In some cases, slaves received brutal beatings by their masters. The wife of a retired judge in Lexington, Caroline Turner once threw a young slave boy from a second story window of their home onto a stone surfaced courtyard, breaking one of the boy's arms and legs, and damaging his spine, leaving him crippled for the remainder of his life. ${ }^{47}$ Mrs. Turner was briefly committed by her husband to an insane asylum and was released after three days, despite a formal investigation, was never prosecuted. ${ }^{48}$ Turner's husband Judge Turner once remarked of his wife's treatment toward their slaves and stated, "She has

\footnotetext{
${ }^{44}$ Coleman, Slavery Times, 247-48; William Littell and Jacob Swigert, eds., A Digest of the Statute Laws of Kentucky (Frankfort, Ky., 1822), 2: 1160; William Littell, ed., The Statute Law of Kentucky, 5 vols. (Frankfort, Ky., 1809-1819), 2:117.

${ }^{45}$ The Examiner, Louisville, October 18, 1848.

${ }^{46}$ Coleman, Slavery Times, 248-49; Cassius Marcellus Clay, The Life of Cassius Marcellus Clay (Cincinnati, 1886), 28.

${ }^{47}$ Ibid, Coleman, 250.

${ }^{48}$ Ibid., 250.
} 
been the immediate death of six of my servants by her severities." ${ }^{49}$ In 1843, Judge Turner died and in his will, he stated, "I have some slaves. I give them to my children. None of them are to go to the said Caroline, for it would be to doom them to misery in life \& a speedy death. ${ }^{, 50}$ However, Widow Turner abnegated the will and took possession of several slaves. Then in what seems a bit of cruel irony, the widow Turner attacked one of her young slaves, who was bound to a wall with chains; the boy managed to break free from the chains and retaliated choking the widow Turner to death. ${ }^{51}$ Fearing his fate the young slave fled. Despite the widow Turner's reputation for mistreating and according to her own husband killing her slaves, the family posted a five hundred dollar reward for the return of the fugitive slave. The young slave was captured in Scott County, tried for murder in Fayette County, convicted, and hanged on the Fayette County Courthouse lawn. ${ }^{52}$ Therefore, to conclude that slavery as practiced in Kentucky was a mild form is erroneous.

To live in a state of slavery was never mild. Under the best circumstances slaves had no legal status or freedom and masters subjected slaves to daily rigorous working conditions. It may be true that working conditions were not as stringent in the Upper South as in the Cotton South states, due to a somewhat milder climate and a shorter growing season; however, work on Kentucky's farms was still quite arduous and hot during the summer months. It is true that Kentucky slaves often worked side by side with their masters. This close position may have lent itself to closer relationships being formed between the two. However, it is just as possible this close positioning of the

\footnotetext{
${ }^{49}$ Theodore D. Weld, American Slavery As It Is: Testimony of a Thousand Witnesses (New York, 1839), 87.

${ }^{50}$ Will of Fielding L. Turner, Fayette County Court, Will Book P, 503-504, dated October 1, 1843.

${ }^{51}$ Lexington Observer \& Reporter, November 19, 1844.

${ }^{52}$ Ibid., November 19, 1844.
} 
master and slave served to reinforce the master's authority as he stood as a constant reminder to his slaves of their subservient position. Masters who worked in close quarters with their slaves, kept a watchful eye on their property and made it difficult for their slaves to communicate with one another. By keeping close contact with their slaves masters posed even greater challenges for slaves who may have contemplated plotting an uprising or escape.

In addition to the master-slave relationship state law and city ordinances also regulated the black-white relationship in an effort to implement racial controls over slaves that prescribed harsh punishment for black slaves who failed to comply with the regulations. Kentuckians had from the state's inception been concerned with the slaves function within society and sought to restrict any freedom or mobility they might attain through statutes known as slave codes. In 1798 Kentucky enacted the first slave code that required bondsmen to carry a pass, issued by a member of the slave owner's family, employer or overseer. The law restricted the slave's mobility to a distance of not more than ten miles from the slave's home. The state law prescribed a punishment for any violator of "ten lashes on his or her bare back."53 Severe punishment was also meted out by the state for slaves who conducted secret "unlawful assemblies" and any white citizen had the power to arrest slaves for carrying out such operations. ${ }^{54}$

Many city ordinances throughout the Commonwealth regulated the slave's ability to function in society as well. In 1853, Falls City adopted an ordinance that sought to examine the activities at church gatherings and restricted worship services from sunrise to 10:00 p.m. on Sundays and from sunset to 10:00 p.m. on Wednesdays. A Louisville

\footnotetext{
${ }^{53}$ William Littell, ed., The Statute Law of Kentucky, 2: 113-14. See also, Kentucky Acts (1849-1850), 48; (1850-51), 1; 301-2.

${ }^{54}$ Ibid., Littell, (1850-51), 1: 301-2.
} 
ordinance sought to curtail public assemblage of black slaves by prohibiting the gathering of more than three blacks from gathering at markets or public places. Another Louisville ordinance prescribed a punishment for slaves who disturbed the peace on Sunday to receive fifteen lashes from the whip. ${ }^{55}$ Curfews for slaves were in place throughout the state. The urban center of the Bluegrass Region, Lexington, had a curfew in place for over sixty years. The city also sought to regulate black's activities by restricting assembly by large numbers of black slaves on the weekends. Night watchmen also conducted patrols between 10:00 p.m. and 6:00 a.m. in Lexington and arrested anyone caught violating the curfew. ${ }^{56}$

Watchmen conducted night patrols were conducted in every Kentucky County. Slave escapes were always a concern as well as slave uprisings or any number of crimes, such as theft or rape. Those counties situated along the Ohio River had to be especially vigilant as the potential for slaves escaping across the river into freedom was a persistent threat. In fact, state law required special vigilance on the part of residents who lived in these northern border counties. Sheriffs monitored all watercraft moored along Kentucky's shore as well as, river crossings. Patrolling agents had the power to arrest on site any slave found loitering along the river's edge. ${ }^{57}$

In addition, to slave escape and criminal activity, just as throughout the rest of the slaveholding South, many Kentuckians, feared slave revolt. Occasional rumors of slaves plotting a rebellion, as well as, occasional episodes of violence on the part of slaves

\footnotetext{
${ }^{55} \mathrm{~J}$. Stoddard Johnston, ed., Memorial History of Louisville From its First Settlement to the Year 1896, 2 vols. (Chicago, 1896), 1:67; Legislative Records of Louisville, Kentucky, November 5 1853, Microfilm Project 10, Reel 45 (235 vols., University of Louisville).

${ }^{56}$ Trustees Minute Book, Lexington, Kentucky, July 7, 1800, September 25, 1801, February 13, 1812, June 17, 1813, December 7, 1854, Microfilm 224 (University of Kentucky).

${ }^{57}$ Kentucky Acts (1850-51), 1: 309-10. The Revised Statutes of Kentucky, 1851 and 1852 (Frankfort, Kentucky, 1852), 520-21.
} 
bolstered white people's fears of an uprising. On August 5, 1848, these fears became reality in Fayette County, in the central Bluegrass Region of the state. Seventy-five armed slaves escaped and fled their masters, and headed north for the Ohio River. Insurrectionists threatened violence and their leader a white student from Centre College, located in Danville. A cash reward of five thousand dollars was offered for the capture of the fugitive slaves and their leader. ${ }^{58}$ Finally, on the morning of August the eighth a message arrived in Lexington from citizens in nearby Harrison County pleading for help. ${ }^{59}$ The message was reprinted in the Lexington Observer \& Reporter and read:

This will inform you that your negroes are now supposed to be surrounded about the county line between Harrison and Bracken, some fifteen or eighteen miles short of the Ohio River. About one hundred of our citizens have been after them since Monday morning last. They are worn down, and it is requested that you send a fresh set of men immediately, say 50 to 100 men, well armed; for it seems they are determined to fight every inch of the ground, as they are armed generally with revolvers, commanded by a white man or more. They were encamped and fortified last night, and our Cynthiana boys came upon about forty or more and a battle ensued, and Charles H. Fowler was mortally wounded. We hear one dead negro was found. Send all you can-speedily, or all will be lost. ${ }^{60}$

Upon receiving the news, a well armed posse of several hundred men gathered and headed for Harrison County; however, before arriving, the posse received the message that the fugitives had been surrounded and after a brief encounter surrendered. ${ }^{61}$ The slaves were tried and three of them hanged at noon, on October 28 , on the courthouse lawn at Brooksville. ${ }^{62}$

In Greenup County, located along the Ohio River in northeast Kentucky, another episode of slave violence occurred. A slave trader, Henry Gordon, had purchased ninety

${ }^{58}$ Lexington Observer \& Reporter, August 9, 1848.

${ }^{59}$ Ibid., August 9, 1848.

${ }^{60}$ Lexington Observer \& Reporter, August 12, 1848.

${ }^{61}$ Ibid.

${ }^{62}$ Maysville Eagle, November 3, 1848. 
slaves in Baltimore and was transporting them to Mississippi. Using a file, several of the male slaves that were chained together managed to break free from the chains. They mutinied, attacked Gordon and his two associates, William B. Petit and Gabriel T. Allen. The slaves killed Petit and Allen. Gordon was shot twice, but the balls only grazed his head the slaves then beat him with clubs and left him for dead. Gordon survived and managed to escape to a nearby plantation to relay details of the violent and deadly attack. $^{63}$

A posse managed to capture several of the slaves were eventually captured. Seven slaves, that included six males and one female believed to be responsible for taking part in the assaults and murders, were tried and convicted in Greenup Circuit Court. ${ }^{64}$ The male slaves hanged on November 20, 1829. However, the female was discovered to be pregnant and was not hanged until after giving birth several months later. ${ }^{65}$

While these episodes of slave insurrection and violence against their masters occurred, they were not the norm and were not prevalent occurrences. These episodes did serve to reinforce the fears of white people that resulted in an increased state of concern and in some cases paranoia on the part of many in Kentucky. White people in the state could and did point to these instances of slave escape, rebellion and in extreme cases, violence and murder to justify the stringent measures implemented throughout the state in an effort to control the slaves so that the two races could live and coexist peacefully. Strict slave codes, curfews, patrols, public floggings and brutal beatings by masters all were implemented as measures of control in Kentucky. Although the institution of slavery in Kentucky may have been less stringent in the Upper South border region than in the

${ }^{63}$ Kentucky Reporter, September 9, 1829.

${ }^{64}$ Greenup Circuit Court, Order Book 11, 158, October term, 1829.

${ }^{65}$ Ibid., 259, April term, 1830, fifth day. 
Lower South cotton states generally, episodes occurred that proved slavery was not mild even in the Bluegrass State. Although most Kentuckians did not describe slavery in their state in positive good terms, they did adopt many similar practices when it came to controlling their slaves and preserving the "peculiar institution" within their state. Whatever their moral concerns and sentiment regarding slavery may have been, Kentuckians proved just as willing and resilient to continue the practice of slavery as their Deep South counterparts.

The necessary evil interpretation fit well with most Kentuckians, who resided in a border slave state in the Upper South and were separated only by the width of the Ohio River from the three free states of Ohio, Indiana and Illinois. The interactions of the people from Ohio, Indiana and Illinois with Kentuckians likely had some influence on their view toward the institution of slavery. Most Kentuckians certainly were not abolitionists and they also did not adopt the "positive good" 66 explanation espoused by most proslavery advocates in the Lower South cotton states. The majority of antebellum Kentuckians believed that slavery, although morally repugnant, was necessary to maintain a well ordered society, where different races of people could peacefully coexist. Kentuckians pointed to their right under the United States Constitution to own property in persons. Over time, Kentuckians proved resilient to change and were not willing to relinquish their property rights as Kentuckians refused to ratify the Thirteenth, Fourteenth

\footnotetext{
${ }^{66}$ See, McPherson, Ordeal by Fire, 51-53. See also, Tallant, Evil Necessity, 10-11. Drew Gilpin Faust, "Introduction: The Proslavery Argument in History," D.G. Faust, ed., The Ideology of Slavery: Proslavery Thought in the Antebellum South, 1830-1860 (Baton Rouge: Louisiana State University Press, 1981), 5-6. Asa E. Martin, "The Anti-Slavery Movement in Kentucky Prior to 1850," Filson Club Publications, no. 29 (1918). William Sumner Jenkins, Pro-Slavery Thought in the Old South (Chapel Hill: University of North Carolina Press, 1935), 39-49. Eugene D. Genovese, The World the Slaveholders Made: Two Essays in Interpretation (New York: Pantheon Publishers, Inc., 1969), 130-136.
} 
and Fifteenth Amendments to the United States Constitution after the conclusion of the Civil War.

The fact that a majority of Kentuckians subscribed to the "necessary evil" theory suggests that the majority of Kentuckians were at least ambivalent regarding slavery. Their ambivalent position allowed many Kentuckians to remain open minded enough regarding slavery so that a discourse could take place within the state between proslavery proponents and antislavery advocates. A genuine, albeit limited, antislavery movement existed and persisted in the state for several decades during the 1800's leading up to the Civil War. Although the antislavery debate existed in Kentucky it proved unsuccessful and was often met with stiff and sometimes violent opposition from proslavery supporters. The fact an antislavery debate occurred in Kentucky suggests Kentuckians were conflicted about slavery on some level. Many recognized the indignity suffered by slaves and may have even felt compassion for those held in bondage and thus, deprived of their natural rights. However, in the end Kentuckians proved unwilling to embrace change and clung to the notion that slavery was necessary to control the so called inferior black race. Kentuckians remained resolute in their unwillingness to relinquish their right to hold property in persons in the decades leading up to the Civil War. Kentuckians continued to cling to their belief that they had a right to hold property in persons, even after the United States Constitution had been amended, in the postwar era, thus putting an end to the "peculiar institution." The majority of Kentuckians subscribed to the necessary evil theory, suggesting their ambivalence regarding the practice of slavery in their state. Kentuckian's ambivalence allowed them to remain open minded enough to question the impact the "peculiar institution" had on the state's economic, legal and 
social institutions. In the end, the majority of Kentuckians remained devoted to the notion that, slavery still held a practical significance for their state. 


\section{CHAPTER II}

\section{THE ANTISLAVERY MOVEMENT IN ANTEBELLUM KENTUCKY}

The institution of slavery in Kentucky was entrenched. Slavery was an essential part of Kentucky's economy and social and cultural institutions. Nonetheless, a significant minority of Kentuckians opposed the peculiar institution. Political actors Cassius Marcellus Clay and Robert J. Breckinridge both espoused gradual emancipation on political and economic grounds. Abolitionists John G. Fee, James G. Birney, Delia Webster, and Calvin Fairbank opposed slavery on moral grounds. Despite their differences, they each promoted an antislavery agenda and sought to end the peculiar institution within Kentucky. The antislavery press brought attention to the debate both locally, but more important nationally. Finally, slaves offered their own resistance to the "peculiar institution" within Kentucky. Although the antislavery movement did not succeed in ending slavery in Kentucky, it did continue slavery agitation within the state. This chapter argues the fact a slavery debate occurred at all in the border slave state Kentucky is significant. Many in Kentucky remained ambivalent regarding the peculiar institution and questioned slavery's practical impact on the Commonwealth's economic and social condition.

Antislavery proponents in Kentucky provided hope for the antislavery advocates throughout the northeast United States who recognized that for their agenda to succeed 
they had to have southern support. ${ }^{1}$ The commonwealth's geographic position between the slave South and the free labor North garnered national attention to the Bluegrass State and its slavery practices. The antislavery movement promoted a sense of ambivalence among abolitionists in the North and proslavery adherents in the South regarding the state's position on slavery. As the sectional crises deepened, many northern and southern eyes turned to Kentucky, owing in no small measure to the efforts of the state's antislavery advocates. Unlike abolitionists in the free-state North far removed from the practice of slavery, antislavery advocates in Kentucky viewed the practice of the peculiar institution first hand. Kentucky's antislavery proponents understood the tragedies inherent in human bondage; however, many also understood the practicality of the "peculiar institution" for slaveholders who were dependent on slave labor, or who at the very least had invested vast amounts of capital in their property in persons.

Therefore, antislavery men in Kentucky saw the adverse consequences slavery posed for their state's economic and social condition; the majority also realized the dire economic and social consequences immediate abolition posed for the Commonwealth. The fact that slavery was a living institution in Kentucky illuminated the complex problems associated with the "peculiar institution." Kentucky's antislavery advocates experienced a closeness to slavery that both facilitated their opposition to the institution; but, that closeness also contributed to a sense that slavery was a necessity for many. ${ }^{2}$ The close proximity from which antislavery men viewed and experienced slavery in the state served to promote divergent positions among the state's antislavery advocates.

\footnotetext{
${ }^{1}$ Stanley Harrold, Abolitionists and the South, 1831-1861 (Lexington: University Press of Kentucky, 1995), 35.

${ }^{2}$ For the most lucid explication of the "Necessary Evil" theory see, Harold D. Tallant, Evil Necessity: Slavery and Political Culture in Antebellum Kentucky (Lexington: The University Press of Kentucky, 2003).
} 
These conflicting antislavery views facilitated a sense of ambivalence among abolitionists in the North, regarding Kentucky's antislavery stance. That an antislavery element existed at all in the state caused grave concern for the proslavery South. Each section understood the key significance the border slave state, Kentucky would hold in any future sectional conflict. As the Union became increasingly sectionalized around the slavery issue, Kentucky's antislavery actions became more prominent for both sections. The antislavery activists within the state espoused various viewpoints, whether emancipationist or abolitionist in tone, that allowed for a vigorous debate on the "peculiar institution" to take place. Dissidence, discord and violence often accompanied the slavery debate in Kentucky proving how contentious the slavery issue proved for the Commonwealth. The fact that slavery could be debated at all in a slave state is perhaps testament to the ambivalent notions Kentuckians held regarding slavery. Located in the border region between the free labor north and the proslavery South, Kentucky's position on the slavery issue was not clear to either section. In fact, the best course to support or oppose slavery was not clear to many Kentuckians. The antislavery advocates espoused varied approaches to ending slavery. Gradual emancipationists and abolitionists both articulated their antislavery views. Although, antislavery adherents in Kentucky did not achieve slavery eradication in the state, their efforts kept the slavery debate alive in Kentucky.

Cassius Marcellus Clay espoused anti-slavery views as a young man. The son of a wealthy slaveholder, Clay attended Yale University and was exposed to antislavery thought. ${ }^{3}$ The young Clay heard the staunch New England abolitionist William Lloyd

\footnotetext{
${ }^{3}$ Lowell H. Harrison and James C. Klotter, A New History of Kentucky (Lexington: The University Press of Kentucky, 1997), 177.
} 
Garrison condemn the institution of slavery. The experience, he later recalled, "was a new revelation to me." He continued, "I then resolved . . that, when I had the strength, if ever, I would give slavery a death struggle."4

Although the young Clay was influenced by northern abolitionist thought, the mature Clay opposed slavery chiefly for economic reasons. He argued that slavery undermined fair competition in the labor market and excluded white laborers. Clay first became aware of the economic disparities between the free labor north and slaveholding south during his 1831 trip to New Haven, Connecticut to attend Yale University. Clay recognized, despite inferior soil, the region enjoyed much economic prosperity. Clay attributed the North's economic success to industrialization and free labor. By contrast, however, Clay realized the South's institution of slavery promoted an agrarian based economy and undermined industrialization and economic growth. ${ }^{5}$

After graduating from Yale in 1832, Clay returned to the Bluegrass to assert himself among the slaveholding elite. Clay inherited a large plantation and more than twenty slaves. Like many of his slaveholding counterparts, Clay had political ambitions. ${ }^{6}$ Clay became a politician, first elected to the state legislature in 1835 , as a state representative of Madison County. By 1840, he sought re-election. The hot button political issue for Fayette County was the Negro Law of 1833. Fayette County had a large number of slaves, with over 10,000 slaves living within its borders in $1840 .^{7}$ The 1833 Non Importation law prohibited the importation of slaves into the state, forcing those who

\footnotetext{
${ }^{4}$ Cassius Marcellus Clay, Life of Cassius Marcellus Clay, Memoirs, Writings and Speeches (Cincinnati, 1886) 55-57.

${ }^{5}$ Jacob F. Lee, "Between Two Fires: Cassius M. Clay, Slavery and Antislavery in the Kentucky Borderlands," Ohio Valley History 6 (Fall 2006): 54-55.

${ }^{6}$ Clay, Writings, 175; David L. Smiley, The Lion of White Hall: The Life of Cassius Marcellus Clay (Madison: The University of Wisconsin Press, 1962), 36.

${ }^{7}$ Cite, Slave Census, $1840-1850$
} 
required additional slave labor to acquire it within the state. For counties with large slave populations the law acted as a tariff. ${ }^{8}$ It enriched slaveholders who could command high prices for their slaves as much as $\$ 1,400$ each, due to labor shortages in other areas of the Commonwealth. ${ }^{9}$ Clay concluded that supporting the law served his political interests well. During his reelection campaign in 1840 , Clay postulated his view on the Non Importation Act of 1833: "Every slave imported drives out a free and independent Kentuckian. ... The day is come, or coming, when every white must work for the wages of the slave . . emigrate, or die!" ${ }^{\prime 10}$ Clay recognized, free white labor could not compete with slave labor; but, was necessary to industrialize Kentucky's economy. It was this platform that won Clay reelection to the Kentucky General Assembly in 1840. His support for restrictions on slave importation into the state ensured the slave population would dwindle over time, but it also, bolstered the economic position of large slaveholders and perpetuated the intra-state slave trade.

In 1840, Clay pronounced, "I believe slavery to be an evil-an evil morally, economically, physically, intellectually, socially, religiously, politically . . an unmixed evil." But Clay did not base his antislavery position on moral grounds. "It is not a matter of conscience with me," he once noted, and "I press it not upon the consciences of others."11

Clay continued to advance an anti-slavery agenda but the expectations and perceptions of the electorate forced him to temper it. In 1841 Clay, once again sought reelection to

\footnotetext{
${ }^{8}$ For a discussion on the Non-Importation Act of 1833, see Tallant, Evil Necessity, 94-96.

${ }^{9}$ David L. Smiley, The Lion of White Hall, 44-49.

${ }^{10}$ Ibid., 49.

"Ibid., 49. Stanley Harrold contends Clay's antislavery stance was rooted in moral and religious sentiments more than was previously thought; however, they contributed only slighty still to Clay's antislavery ideology; see Harrold, "Clay on Slavery and Race," 42-56.
} 
the state legislature. Clay's free labor argument however did not garner the support among Fayette County voters, it had the year before. Clay's opponent Robert Wickliffe, Jr., son of the largest slaveholder in the state, countered Clay's free labor message, by depicting Clay as an abolitionist. In the end, Fayette County elected Wickliffe to the legislature. After his 1841 electoral defeat, Clay argued against slavery, stating "not because the slave is black or white-not because we love the black man best, for we do not love him as well . . but because it is just." ${ }^{\prime 12}$ His primary concern was economic justice for free white laborers, rather than for moral justice for the slave. Clay believed nonslaveholding free white laborers must work for their own economic interests rather than appease the slave holders' and maintain the status quo. However his political failure, reflected Clay's inability to understand the relationship between planters and yeoman farmers. According to historian David Herbert Donald, many contemporaries failed to understand the concept of a herrenvolk democracy or "[T]he southern class system." "No sharp cleavages existed between slave owner and non-slaveholder," he writes. "Instead, they were bound together by ties of kinship, friendship, and economic opportunity."

In addition, non-slaveholding whites held a social status higher than that of black slaves. Poor whites did not want to see their status eroded and feared being placed on an equal footing with free blacks. Many poor whites also aspired to become slave owners themselves. As a result, poor whites had incentives to support the institution of slavery. Clay could never overcome this sentiment and many proslavery advocates depicted him as an abolitionist for attempting to do so.

\footnotetext{
${ }^{12}$ Lowell H. Harrison, The Anti-Slavery Movement in Kentucky (Lexington: The University Press of Kentucky, 1978), 50.

13 David Herbert Donald, "The Proslavery Argument Reconsidered," Journal of Southern History 37 (February 1971): 6.
} 
Nonetheless, Clay continued to espouse his antislavery views. In 1849, Clay called for a state constitutional convention to address the slave question. He advocated gradual emancipation to alleviate the economic consequences for settlers of an immediate end to the institution. In an August 1845 speech, Clay stated that "Although I regard slavery as opposed to natural right, I consider law, and its inviolate observance, in all cases whatever, as the only safeguards of my own liberty and the liberty of others." "In a Convention-which is politically omnipotent," he continued, "I would say that every female slave, born after a certain day and year, should be free at age twenty-one. This, in the course of time, would gradually, and at last, make our state truly free."14

In 1849 , Clay got his wish as the Kentucky legislature called a state constitutional convention. The convention was called to order on October 1, 1849, with more than one hundred and fifty delegates representing twenty-four counties. Clay, Robert J. Breckinridge, and John G. Fee were among the delegates. The Presbyterian Herald estimated that more than 50 percent of the delegates were slave holders who collectively owned over three thousand slaves. ${ }^{15}$ Clay and his antislavery allies framed their argument in economic terms. They contended that slavery was a drag on the state's economy, depressed the wages of free white laborers, and contributed to the economic deprivation of the working class. Antislavery advocates also argued that slaves should enjoy the right of freedom though they usually accompanied this contention with support for colonization of the freed slaves. ${ }^{16}$ Despite their arguments, the pro-slavery element

\footnotetext{
${ }^{14}$ Cassius Marcellus Clay, The Writings of Cassius Marcellus Clay: Including Speeches and Addresses ed., Horace Greeley, (New York: Harper \& Brothers, Publishers, No. 82 Cliff Street, 1848), 292.

${ }^{15}$ See, James P. Gregory, Jr., "The Question of Slavery in the Kentucky Constitutional Convention of 1849," Filson Club History Quarterly, 23 (April 1949): 92. See also, Martin, Anti-slavery Movement, 130131.

${ }^{16}$ Harrison, The Antislavery Movement in Kentucky, 58.
} 
defeated Clay and his anti-slavery supporters. After bloodshed and even murder, ${ }^{17}$ Clay and his antislavery agenda suffered a crushing defeat at the 1849 Kentucky constitutional convention. $^{18}$

Events during the summer of 1849 leading up to the constitutional convention in October illustrates the seriousness and zeal with which proponents on both sides of the slavery debate pursued their respective agendas. Passion, fervor and even violence often accompanied the lively slavery debates. People in cities, towns and communities across the state became caught up in the often intense and heated speeches, meetings and rallies. Centre College President, John C. Young, engaged in an impassioned debate with his proslavery nemesis Captain George B. Kinkead, at the First Presbyterian Church in Danville, for three days. ${ }^{19}$ In June, in Trimble County, proslavery proponents gathered at a mass meeting and called for United States Senator Henry Clay to resign his Senate seat due to his pro emancipation view. ${ }^{20}$ In July, a slavery discussion turned violent, when the Honorable Judge James Campbell fired a gunshot that killed his proslavery opposition candidate for the approaching constitutional convention, the Honorable Judge Benedict Austin. $^{21}$

The central Bluegrass Region was home to more slaveholders than any other area in the state. It was there where the most infamous incidence of violence occurred. Fayette County, served as the county seat for Lexington, the region's largest city. According to the Louisville Courier, "Old Fayette . . is the theatre of a more lively discussion on the

\footnotetext{
${ }^{17}$ Smiley, Lion of White Hall, 138-142.

${ }^{18}$ Martin, Anti-slavery Movement in Kentucky, 138.

${ }^{19}$ Louisville Weekly Journal, May 26, 1849.

${ }^{20}$ Ibid., June 9, 1849.

${ }^{21}$ Lexington Observer \& Reporter, July 18, 1849.
} 
subject of slavery than any other portion of the state."22 The lively slavery discussion turned violent and deadly on June 15, 1849 at the community of Foxtown, located on the Lexington-Richmond turnpike, near Lexington.

Representing Madison County as the pro-slavery candidate for the impending constitutional convention, Squire Turner delivered a rousing speech to a raucous crowd at a political gathering there. During his address, Turner attacked his antislavery opposition candidate to the constitutional convention, Cassius Marcellus Clay, and his antislavery newspaper, The True American with derisive remarks. Never one to back down from a political squabble or fight, Clay retorted with an impassioned and contemptuous counterassault on his opponent. Turner's oldest son Cyrus Turner soon objected, however, and emerged from the crowd shouting: "You're a damned liar!" Clay leaped from the platform to confront his challenger and Turner responded by delivering a blow to Clay's face. $^{23}$

The proslavery crowd soon gathered around and surrounded Clay who made an effort to draw his trusty bowie knife but was struck in the head by someone in the crowd with a club. Someone else managed to grab Clay's knife from his grip. Squire Turner's son, Thomas, then aimed a revolver at Clay's head at point blank range and snapped it three times. Auspiciously for Clay the percussion caps did not explode and the gun failed to discharge. Despite his best efforts to defend himself, Clay was stabbed from the rear, and to prevent being stabbed a second time, Clay clutched the knife by the blade and wrested it from his assailant's hand. Clay's effort resulted in his fingers nearly being cut off. Clay fended off his attackers and thrust his knife into Cyrus Turner's abdomen.

\footnotetext{
${ }^{22}$ Louisville Courier, July 4, 1849.

${ }^{23}$ Coleman, Jr., Slavery Times in Kentucky, 314-315.
} 
Turner died several hours afterwards and many feared Clay was so seriously injured that he would not survive his wounds. ${ }^{24}$ On June 20,1849 , the Lexington Observer \& Reporter gave the following account of the incident, "Mr. Clay still lives, but his adversary Mr. Turner lingered in great agony until 12 o'clock on Saturday night when he expired."25

The bloody encounter at Foxtown further heightened the tensions between the proslavery forces and antislavery advocates. Both sides used the affair against the other. The proslavery proponents hailed Cyrus Turner as a martyr, who died "in the great cause of white supremacy." 26 Others proclaimed he fell victim to the "abolitionist madman C.M. Clay," 27 who had been labeled by his proslavery adversaries as "a damned nigger agitator.",28

By contrast, the antislavery advocates denied responsibility in the fatal affair at Foxtown, claiming that the violent episode was a desperate effort by the proslavery proponents to use coercion and intimidation to thwart their emancipationist efforts. In the end, it was Cassius Clay who survived the Foxtown affair and thus, in the short term, triumphed over the proslavery forces. ${ }^{29}$ Clay's indomitable spirit proved his resilience and showed his resolve in resisting the coercive tactics of the proslavery advocates. The violent episodes that occurred leading up to the 1849 Constitutional Convention is testament to the strong beliefs held by both sides, as men were willing to sacrifice life and limb for their cause.

\footnotetext{
24 Ibid., 315-316.

${ }^{25}$ Lexington Observer \& Reporter, Wednesday, June 20, 1849. See also, the Louisville Weekly Journal, June 30 , July 14, 1849.

${ }^{26}$ William H. Townsend, Lincoln and his Wife's Home Town (Indianapolis: , 1929), 198.

27 Ibid.

${ }^{28}$ Ibid.

${ }^{29}$ Coleman, Slavery Times in Kentucky, 316.
} 
These violent episodes further illuminate the courage and zeal of the antislavery men, outnumbered as they were throughout the state. Their unwillingness to back down from their proslavery adversaries illustrates the determination and courage of the antislavery men in Kentucky. In the end, efforts by antislavery men such as, Cassius Marcellus Clay failed to achieve emancipation in the state, however, their bold actions continued to bring attention to the contentious slave issue and kept the slavery debate alive in the border slave state Kentucky.

A Presbyterian minister and member of a prominent Kentucky political family, Robert J. Breckinridge was also staunchly antislavery. Although some antislavery supporters criticized him for failing to support the 1849-50 constitutional convention, Breckinridge argued that the existing state constitution enabled the legislature to end slavery by passing a law that freed the newborn children of slaves. Breckinridge's gradual emancipation plan lessened the economic impact on slaveholders compared to immediate abolition plans. Breckinridge also advocated colonization, paid for by placing a tax on slaves and paid by slaveholders over time. ${ }^{30}$ In 1831 , Breckinridge argued that "colonization took for granted, the fact that slavery was a great moral and political evil and the [Kentucky Colonization Society] cherished the hope and the belief also, that the successful prosecution of its objects would offer powerful motives and exert a persuasive influence in favor of emancipation. And it is with this indirect effect of the society that the largest advantage is to result to America." ${ }^{, 31}$

After the Kentucky General Assembly rejected an 1851 petition Breckinridge stated, "It is generally known that the original members of the American Colonization Society

\footnotetext{
${ }^{30}$ Ibid., 100-101.

${ }^{31}$ As cited in, Martin, 54.
} 
anticipated, that at some future period, the general government and some if not all of the state governments would co-operate in their exertions for the removal of an evil which was obviously national in all its aspects, and which no private exertions were adequate to extinguish." 32 In an April 1849 meeting held in Lexington to elect delegates for the state constitutional convention, Breckinridge:

resolved that slavery was contrary to the rights of mankind, opposed to the fundamental principles of free government, inconsistent with a state of sound morality, hostile to the prosperity of the Commonwealth and that in the forthcoming constitutional convention steps should be taken to ameliorate the condition of slaves, in such a way as shall be found practicable in itself, just as regards the masters of slaves, and beneficial to the slaves themselves. ${ }^{33}$

Well known and respected throughout the state, Breckinridge embarked on a speaking campaign to raise awareness and support for antislavery in the upcoming convention. He also published and distributed a pamphlet throughout the state entitled, "Platform of Emancipation." It called for the prohibition of slave importation into the commonwealth, and proposed a plan for the gradual emancipation of slaves. He believed the decision remove freed slaves should be left to the people through constitutional amendment or referendum. Breckinridge believed his plan made concessions to proslavery supporters, but dealt with the slave question in a practical and meaningful way. ${ }^{34}$

A Presbyterian minister, Breckinridge worked to promote his antislavery views within the church. Though many church leaders did not critique slavery for fear of alienating slaveholding church members, Breckinridge persisted in his quest to spread his antislavery message. Due in large part to his efforts, the Synod of Kentucky eventually

\footnotetext{
${ }^{32}$ Ibid., 58.

${ }^{33}$ The Lexington Atlas, April 17, 1849. See also, The Examiner, April 14, 1849. The Presbyterian Herald, April 19, 1849.

${ }^{34}$ Lexington Observer and Reporter, June 30, July 4, 1849.
} 
rejected slavery and decided to educate slaves to prepare them for freedom. The church also explicated a plan of gradual emancipation. ${ }^{35}$

Clay and Breckinridge worked to push their antislavery agenda into the political arena. Both advocated gradual emancipation. Clay opposed the peculiar institution on economic grounds, but believed slaves had a legal and constitutional right to be free. Breckinridge based his antislavery arguments on economic and moral grounds. He believed slavery was a "great moral evil," and expressed disdain when his Church failed to act against the “evil institution.” In 1833, he declared, "God has left you, and I also will now leave you." ${ }^{\text {36 }}$ Although Clay and Breckinridge did not achieve their antislavery goals, they both advocated for slavery's eradication from within Kentucky. They worked to keep the slavery debate alive in Kentucky, refusing to mute their voices before the proslavery majority.

James G. Birney also figured a prominent player in Kentucky's antislavery movement. A native Kentuckian, Birney had resided for many years outside the state in Alabama. In 1833 Birney returned to the Commonwealth and settled on a farm in the Bluegrass Region of central Kentucky, near his native Danville. Birney was born into a prominent aristocratic Kentucky slaveholding family and by the age of twenty nine himself owned forty-three slaves. ${ }^{37}$ Upon returning to his native Kentucky, Birney manumitted his slaves. Birney had considered the evils of slavery since his childhood. He entered Transylvania University in nearby Lexington at age eleven. Birney later transferred to the College of New Jersey, later known as Princeton University, where he was exposed to

\footnotetext{
${ }^{35}$ Harrison, The Antislavery Movement in Kentucky, 54-55.

${ }^{36}$ Hambleton Tapp, "The Slavery Controversy between Robert Wickliffe and Robert J. Breckinridge prior to the Civil War," Filson History Quarterly 19 (July 1945): 163.

${ }^{37}$ Betty Fladeland, James Gillespie Birney: Slaveholder to Abolitionist (New York: Greenwood Press, Publishers, Reprint 1969), 18-19.
} 
an even stronger antislavery sentiment than he had experienced in varying degrees in his native Kentucky. ${ }^{38}$ His religious conversion as an adult spurred his antislavery devotion. ${ }^{39}$ Over time Birney transformed from a slaveholder, who realized the evils inherent in slavery, but also the practical necessity for a cotton planter in Alabama to own slaves, into an advocate for gradual emancipation and colonization and finally into an abolitionist. $^{40}$

Birney began his antislavery efforts soon after his return to the Commonwealth when he organized The Kentucky Society for the Relief of the State of Kentucky from Slavery. After increasing its membership from nine to approximately twenty members over the following two to three years the organization faltered. Undeterred in his antislavery efforts, in 1835 Birney founded the Kentucky Antislavery Society. ${ }^{41}$

Birney's antislavery efforts gained national attention. National abolitionists and antislavery advocates such as William Lloyd Garrison and Benjamin Lundy took notice. Birney corresponded with Garrison and convinced him to include the Kentucky Antislavery Society within his American Antislavery Society. Birney's connection to the radical abolitionist Garrison sparked a firestorm among the local community. Garrison's antislavery platform called for the abolition of slavery. This radical plan by Kentuckians' conservative standards stood in contrast to the moderate approach to antislavery that had always prevailed in the state that called for gradual and compensated emancipation, often followed by colonization. Birney himself, along with prominent political actors within

\footnotetext{
${ }^{38}$ Ibid., 3-8.

${ }^{39}$ Ibid., 30-31.

${ }^{40}$ Ibid., as slaveowner, 19, 72-73; advocate for colonization, 38-39; as gradual emancipationist, 77-80; as abolitionist, 82-83, 171 .

${ }^{41}$ J. Winston Coleman, Jr., Slavery Times in Kentucky (Chapel Hill: The University of North Carolina Press, 1940), 298.
} 
the state such as Henry Clay, Cassius M. Clay, and Robert J. Breckinridge had advocated for colonization and belonged to the American Colonization Society and the Kentucky Colonization Society. ${ }^{42}$ Kentucky's political actors recognized that many Kentuckians viewed slavery as a moral evil. While many considered slavery a threat to a progressive free labor society based on manufacture and commerce. Despite one's motive for opposing the peculiar institution, however, in Kentucky antislavery advocates were overwhelmingly conservative and favored a gradual course of compensated emancipation, often followed by colonization.

Birney's close association to a well known abolitionist from the Northeast caused many to label Birney an abolitionist. In May, 1834, he confirmed their fears and resigned from his duties in the Kentucky Colonization Society and the Kentucky Society for the Gradual Relief of the State from Slavery. He followed these actions and took the bold next step and manumitted his slaves. Birney had come to believe that colonization was inadequate to challenge slavery as an institution that was so interwoven in the fabric of the proslavery South. ${ }^{43}$ Birney argued colonization allowed slavery to exist in the present and only indicted the institution at some distant point in the future. In Birney's mind colonization did not address slavery on moral grounds rather it served white society by removing a drag on the economy and also by removing the majority of the black population from society. Thus, colonization constituted a device that served the interests of whites; not blacks. ${ }^{44}$ Even in a border slave state such as Kentucky where a moderate approach to the slave issue had been espoused by many in the state, few existed who

\footnotetext{
${ }^{42}$ Harold D. Tallant, Evil Necessity: Slavery and Political Culture in Antebellum Kentucky (Lexington: The University Press of Kentucky, 2003), 41-44, 118-120, 49-52.

${ }^{43}$ Fladeland, James Gillespie Birney, 81-87.

${ }^{44}$ Ibid., 86.
} 
were willing to forgo gradual emancipation for outright abolition. Therefore, Birney could expect backlash among the public within the state, including many conservative antislavery adherents.

The antislavery press played an important role in the cause. Clay rose to prominence as an editor of an antislavery newspaper. In 1845, he began publication of his Lexingtonbased newspaper, the True American. Clay used the paper to publicize his gradual emancipation views. The first edition of the paper had two thousand subscribers, but only three hundred of those lived in the state, and the paper soon came under attack from proslavery proponents within the Commonwealth. ${ }^{45}$ Arguing that Clay's paper posed a threat to public safety, on August 18, 1845, a mob gathered at the Fayette County courthouse to silence Clay. Slaveholder Thomas F. Marshall declared, "Such a man and such a course is no longer tolerable or consistent with the character or safety of this community. . . the negroes might well, as we have strong reason to believe they do, look to him as a deliverer.. . . A Kentuckian himself, he should have known Kentuckians better." ${ }^{46}$ The crowd then seized Clay's printing press and transported it to Cincinnati. Frederick Douglass praised the True American as "one of the most hopeful and soul cheering signs of the times,--a star shining in darkness, beaming hope to the almost despairing bondsman." ${ }^{, 47}$ Clay continued to publish his paper for a short time in Cincinnati. However, he never gained enough support in Kentucky to keep his paper

\footnotetext{
${ }^{45}$ Harrison, The Antislavery Movement in Kentucky, 51.

${ }^{46}$ Cincinnati Gazette, August 22, 1845; W.L. Barre, ed., Speeches and Writings of Hon. Thomas F. Marshall (Cincinnati, Ohio, 1858), 198-209.

${ }^{47}$ Carter G. Woodson, ed., Mind of the Negro as Reflected in Letters Written during the Crises, 1800-1860 (Washington, D.C., 1926), 395.
} 
afloat. Clay grew weary of the publication, abandoning it to participate in the Mexican War. $^{48}$

The True American continued after Clay ceased publication. An antislavery South Carolinian, John C. Vaughan, took over the paper; but, it lost favor with abolitionists in the North after Clay joined the Mexican War. Subscriptions fell and Cassius's brother Brutus Clay, who oversaw the newspaper in Cassius's absence, ceased operations. ${ }^{49}$

After the True American closed, Vaughan began in Louisville his own antislavery newspaper, The Examiner. Vaughan's paper advocated a moderate approach to the slave question, calling for gradual emancipation. Vaughan hired Baptist minister James M. Pendleton to write for the Examiner. Between September 1847 and June 1848, Pendleton wrote twenty influential articles in favor of emancipation. Pendleton left the paper and moved out of state, and the Examiner ceased operations in $1851 .^{50}$

In 1850, William Shreve Bailey began an antislavery newspaper in Newport. Bailey’s newspaper underwent numerous name changes but was best known as Newport News and the Free South. Bailey based his antislavery arguments, like Cassius Clay, on economics. Bailey argued that white labor suffered because of slave labor. He differed from Clay, however, in advocating for immediate emancipation. Despite the fact that Bailey advanced his abolitionist views in a hostile proslavery environment he continued his paper for ten years. ${ }^{51}$ The newspaper's longevity was a feat considering that many other southern antislavery newspapers operated for only one or two years, or even a few

\footnotetext{
${ }^{48}$ See Lowell H. Harrison, "Cassius Marcellus Clay and The True American," in Filson Club History Quarterly, 22 (January 1948). See also, Filson Club History Quarterly, 29 (October 1955): 320-23. For a complete account of Clay's True American, see David L. Smiley, Lion of White Hall, 90-105.

${ }^{49}$ Harrison, The Antislavery Movement in Kentucky, 53.

${ }^{50}$ Smiley, 115. See also, Harrison, 53-54.

${ }^{51}$ Will Frank Steely, "William Shreve Bailey, Kentucky Abolitionist," Filson Club History Quarterly 31 (July 1957): 274-281.
} 
months. Bailey's accomplishment is more impressive given the adversity he faced through the years. In 1851 , an angry proslavery mob burned his building to the ground. He also faced multiple lawsuits, including libel and one for personal injury damages after the victim attempted to assault Bailey with a cane. Bailey faced hostility for his antislavery and pro-Republican Party views.

Bailey's paper provided extensive coverage of national events, including the 1854 Kansas-Nebraska Act, the bloody conflict over the Lecompton Constitution in Kansas and the United States Supreme Court's Dred Scott v. Sandford (1857) decision. In each case, Bailey articulated a pro-Republican Party and antislavery position, igniting the fury of local proslavery men. After John Brown's October 1859 attack on Harper's Ferry hostility toward Bailey and his anti-slavery newspaper heightened. An angry crowd stormed Bailey's building and threw his printing presses into the streets. Despite these attacks, Bailey refused to cease publication of the Newport News. In response, local officials arrested and tossed him in jail for seditious writing. ${ }^{52}$ Bailey resisted the proslavery opposition and continued to spread his antislavery message.

James G. Birney also desired to publish an antislavery newspaper, The Philanthropist, in the state. Birney hoped to publish the first edition in Danville in August, 1835. Birney hoped that the paper would serve as a medium for the Kentucky Antislavery Society and would promote the abolitionist ideals advanced by William Lloyd Garrison's American Antislavery Society. Immediately upon learning of Birney's planned paper, slaveholding opposition throughout the state made known their antipathy for such abolitionist actions. Public meetings were organized to discuss plans to thwart Birney's plan to establish his

\footnotetext{
${ }^{52}$ Wallace B. Turner, "Abolitionism in Kentucky," Register of Kentucky History Society 69 (October 1971): 337-38. See also, Stanley Harrold,
} 
antislavery paper. Threats of mob violence against Birney were common. A committee of thirty three citizens explicated a detailed warning to Birney. Amid death threats to anyone responsible for printing the antislavery paper Birney realized that Danville, Kentucky was not the place for his printing exploits. In 1836, Birney moved his printing operation north of the Ohio River to Cincinnati, where he began publication of The Philanthropist. Although located in a free state, Cincinnati was still linked with close ties to the proslavery South and in 1836 a mob attacked Birney's printing press destroyed it. ${ }^{53}$ Birney never published his antislavery paper in Kentucky. Despite a relatively moderate approach to slavery by many within the state, that included an antislavery element, resistance to antislavery efforts in the press proved to difficult to overcome.

The antislavery press in Kentucky had few readers in the state. Most white Kentuckians supported slavery and few people wanted to hear an antislavery message. Clay used his newspaper the True American to propound a moderate antislavery message that opposed the peculiar institution on economic grounds. Vaughan continued Clay's moderate antislavery message, espousing gradual emancipation view as editor of the True American as well as his paper The Examiner. Bailey's call for the immediate emancipation sparked much controversy, protest, and violence. While none of these newspapers garnered much support within the state, they gained recognition and support from antislavery northerners. Abolitionists like William Lloyd Garrison and Frederick Douglass both took notice, and offered their support for these antislavery Kentucky newspapers.

Although these papers failed to gain a large following in Kentucky, they promoted the idea that slavery was wrong for economic, constitutional and moral reasons. In addition,

${ }^{53}$ Coleman, Slavery Times in Kentucky, 298-300. 
the antislavery press brought national attention to the state's debate over slavery. The fact that an anti-slavery press existed at all in a slave state provided hope to many in the free states that someday the peculiar institution could be eradicated.

Other Kentuckians also worked to keep antislavery alive in Kentucky, including abolitionist John G. Fee. Fee was a native Kentuckian whose family owned slaves. He attended Augusta College and Miami University and then studied to become a Presbyterian minister at Lane Seminary. ${ }^{54}$ At Lane Seminary Fee embraced abolitionism. He opposed slavery on moral grounds, arguing in a letter to Lewis Tappan, "In whatever way we enter our protest against slavery it must be for the good reason that it is sin against God." ${ }^{, 55}$ Fee adopted an adamant antislavery stance, refusing to accept slaveholders in his church. "In our church we have no slaveholders," he wrote, "nor as long as I am pastor of it, will there be any." 56 Fee's strong antislavery views were more than many Presbyterian leaders would tolerate. In particular, they worried about alienating slaveholding churches, and in 1845 relieved Fee of his ministerial duties. ${ }^{57}$ However, Fee was undeterred in his effort to promote freedom for the slaves and equality among the races. Following his dismissal from the Presbyterian Church he began his own church that recognized black as equals. ${ }^{58}$

In 1848, Fee became a member of the American Missionary Association, an evangelical group that promoted an antislavery agenda. With the missionary association's support, Fee established a number of small churches in rural Kentucky. ${ }^{59}$

\footnotetext{
${ }^{54}$ Harrison, The Antislavery Movement in Kentucky, 68.

55 Ibid., 69.

${ }^{56}$ John G. Fee, Autobiography of John G. Fee (Chicago, 1891).

${ }^{57}$ Harrison and Klotter, A New History of Kentucky, 178.

58 Ibid.

${ }^{59}$ Richard Sears, The Kentucky Abolitionists in the Midst of Slavery 1854-1864: Exiles for Freedom (Lewiston: The Edwin Mellen Press, 1993), 49-51. Fee, Autobiography, 43.
} 
The association also underwrote several of Fee's antislavery pamphlets. Among them was his influential, Anti-Slavery Manual, in which he argued for equality among blacks and whites. In 1851 he wrote, The Sinfulness of Slaveholding, laying out all the verses in the Bible supported slavery and painstakingly refuting them all. ${ }^{60}$ Fee expressed his moral abhorrence of slavery when he wrote:

I have seen women tied to a tree or a timber and whipped with cowhides on their bare backs until their shrieks would seem to rend the very heavens. I have seen a man, a father, guilty only of the crime of absenting himself from work for a day and two nights, on his return home whipped with a cow-hide on his bare flesh until his blood ran to his heels. Yet this torture of the body was the least part of the agony of slavery... . The acme of the crime was on the soul. The crushing of human hearts, sundering the ties of husband and wife, parent and child, shrouding all of manhood in the long night of despair the crime was on the soul! ${ }^{61}$

Clay urged Fee to move to the southeast part of the state, near Berea, where the Bluegrass Region met the foothills of the Appalachian Mountains. Clay wanted to forge a political base of support in an area where there were few slaveholders. ${ }^{62}$ Clay offered Fee ten acres of land, where he could build a house and school. Fee moved to Berea and began preaching his abolitionist message. He built a settlement and several antislavery allies settled in the area. However, Fee and his adherents encountered stiff resistance from proslavery mobs. After several years of threats, harassment, and removal from churches, in the winter of 1859 Fee and his abolitionist supporters left Berea. ${ }^{63}$

Fee failed to convince Kentuckians to abolish slavery. He delivered his antislavery message in sermons throughout the state, in speeches at political events, and in his antislavery pamphlets. He brought attention to the issue of slavery and hoped that in his

\footnotetext{
${ }^{60}$ Sears, $30,74$.

${ }^{61}$ Ibid., 75. See also, Fee, Autobiography, 69-70.

${ }^{62}$ Harrison and Klotter, 178.

63 Ibid.
} 
message would appeal to people's sense of morality and convince them to rid themselves of the "evil institution" of slavery.

Abolitionist Delia Webster played a prominent role in the antislavery movement in Kentucky. She helped slaves escape from Kentucky across the Ohio River into freedom. A native of Vermont, in 1843 Webster moved to Lexington, Kentucky. The following year the local grand jury charged her with assisting three slaves in their escape from Kentucky to Ohio. At trial, the jury found her guilty on one count, the theft of Lewis Hayden. The jury that convicted her recommended a two year sentence in Kentucky's state prison. ${ }^{64}$ However, the jury, citing Webster's gender, appealed to Governor William Owsley to grant a pardon in her behalf. Webster entered prison on January 19, 1845. Governor Owsley granted the pardon, on February 25, 1845, despite much protest from many proslavery supporters. ${ }^{65}$ Webster left the state, but returned in 1854 to live on the farm she had purchased in November, 1852 in Trimble County on the Ohio River. Her farm became a popular stopping point on the Underground Railroad, as fugitive slaves attempted their escape to Indiana. ${ }^{66}$

Many of Webster's neighbors suspected her of antislavery activities and on February 4, 1854 held a meeting in the Bedford, Trimble County Courthouse. The purpose of the meeting was to discuss actions necessary to stop Webster's "slave stealing." The Louisville Democrat reported Webster as saying, "Flaming and exciting speeches were made ... and plans concocted to drive me from the state. ${ }^{, 67}$ The participants adopted measures that stated, "Whereas it is known that Miss Delia A. Webster has recently run

\footnotetext{
${ }^{64}$ Randolph Paul Runyon, Delia Webster and the Underground Railroad (Lexington: The University Press of Kentucky, 1996), 52-54. See also, the Frankfort Commonwealth, December 31, 1844.

${ }^{65}$ Ibid., 54

${ }^{66}$ Ibid., 164-67.

${ }^{67}$ Louisville Democrat, February 15, 1854.
} 
off numerous slaves from Trimble County, therefore resolved that it is the will and determination of the citizens of said county that Miss Delia A. Webster leave the state." 68 One month later the mob of protestors paid Webster another visit. This time the mob stated their demands, "Unless you consent forthwith to sell us your plantation, and speedily leave the state no more to return, you will be mobbed at a dead hour of the night, and the threats of the mass executed." The threats had been delivered previously, "Your fences will all be torn down, your fine orchard ruined, your valuable timber destroyed, your cattle and horses slain before your eyes, your barns and out-houses burned, your dwelling houses blown up, and yourself assassinated at the midnight hour." ${ }^{69}$ Webster was left alone for the time being but, the harassment continued.

One week later the sheriff arrested Webster for aiding slaves to escape. The Madison Courier reported on the trial and objected to the proceedings. Especially erroneous was the idea one could be convicted on the mere suspicion of "enticing away slaves" when "There was no pretence of any evidence" the paper noted however, "it was shown that since her residence in that county some twenty slaves had escaped." ${ }^{, 70}$ The local jury again convicted Webster and lodged her in jail, where she was subjected to brutal and harsh conditions. Finally, the sheriff moved Webster was moved to another jurisdiction on a writ of habeas corpus and released her from custody on April 8, 1854. Webster kept her farm, but left its operation in the care of tenants and moved to Madison on the north side of the Ohio River. ${ }^{71}$ Proslavery advocates burned Webster's property several times until she fled from Kentucky.

\footnotetext{
${ }^{68}$ Ibid.

${ }^{69}$ New York Independent, November 29, 1855.

${ }^{70}$ Madison Courier, March 22, 1854.

${ }^{71}$ Ibid., Runyon, Delia Webster, 186.
} 
Calvin Fairbank was also a prominent abolitionist who offered support to the antislavery cause. On one occasion he bought a beautiful slave girl named Eliza for $\$ 1485.00$ from a Lexington slave pen. When asked by a crowd member, "What are you going to do with her?" He retorted, "Free her, sir," igniting a roaring applause from the crowd. ${ }^{72}$ Calvin Fairbank also figured a prominent player on the Underground Railroad assisting many slaves escape into freedom. Upon his graduation from Oberlin Theological Seminary at age twenty-eight he had assisted forty three slaves escape to freedom. ${ }^{73}$ Calvin Fairbank met and worked in concert with Delia Webster to help slaves escape across the Ohio River and into freedom. A mob caught them in 1844 and they stood trial together in December $1844 .^{74}$ In February 1845, a jury convicted Fairbank of slave stealing and sentenced him to serve fifteen years in prison. Auspiciously for Fairbank, in 1849 , Governor John J. Crittenden pardoned him. ${ }^{75}$ However, Fairbank continued his antislavery efforts and he was accused a second time for slave stealing that led to a second conviction. This time Fairbank was again sentenced to fifteen years but, served all but three, before being pardoned in $1864 .^{76}$ Fairbank performed hard labor and according to him endured over one thousand whippings. ${ }^{77}$ Fairbank recalls his experience in his memoirs:

For aiding those slaves to escape from their bondage, I was twice imprisoned-in all seventeen years and four months; and received ... thirty-five thousand, one hundred and five stripes from a leather strap fifteen to eighteen inches long, one and a half inches wide, and from one-quarter to three-eights of an inch thick. It was half-tanned leather, and frequently well-soaked, so that it might burn the flesh more intensely. These floggings were not with a rawhide or cowhide, but with a

\footnotetext{
${ }^{72}$ Coleman, Slavery Times, 131, 158-59.

${ }^{73}$ Runyon, Delia Webster, 4.

${ }^{74}$ Ibid.,47-8.

${ }^{75}$ Ibid., 122-23.

${ }^{76}$ Ibid., 198.

${ }^{77}$ Harrison and Klotter, A New History of Kentucky, 171.
} 
strap of leather attached to a handle of convenient size and length to inflict as much pain as possible, with as little real damage as possible to the working capacity. ${ }^{78}$

Fairbank proved determined in his efforts to resist slavery at all costs to himself. His courage and resolve did not go unrecognized, as prominent antislavery Northerners took notice. Fairbank also engaged in speaking tours spreading his antislavery message and recounting the details if his personal experiences, throughout the northeast. Prominent abolitionists such as Lewis Hayden, Ralph Waldo Emerson, William Lloyd Garrison and Wendell Phillips, all attended his lectures. ${ }^{79}$ In addition to his slave rescuing efforts his lectures to northern audiences provided hope that an antislavery cause in the South could indeed occur. Members of the abolitionist press such as William Lloyd Garrison printed accounts of Fairbanks actions brought wide attention to his antislavery actions and spurred on the antislavery sentiment throughout the northeast.

Slaves also offered much resistance to slavery. Their resistance took on many different forms. Many slaves failed to perform their tasks well. Often, slaves performed their duties slowly, causing inefficiency for the slave owners. Many slaves feigned sickness while others would sometimes injure themselves. A less chosen from of resistance was suicide. While rare, suicide did occur, but usually only amid extreme circumstances such as following a failed escape, or when facing, or after receiving brutal punishment at the hands of the slaveholder. ${ }^{80}$

Another form of resistance was the destruction of property by slaves. Many slaves lost tools, or damaged their master's tools. While other slaves would abuse the

\footnotetext{
${ }^{78}$ Calvin Fairbank, Rev. Calvin Fairbank during Slavery Times: How He" Fought the Good Fight" to Prepare "The Way." (Chicago: R.R. McCabe, 1890).

${ }^{79}$ Runyon, 142-43.

${ }^{80}$ Harrison and Klotter, 170.
} 
slaveholders' animals, cause damage to or even destroy crops as well as even burn the slaveholder's barns and out buildings. Further, slaves resorted to helping themselves to food from the master's cupboard. ${ }^{81}$

On occasion slaves resorted to violence. In Daviess County, several of his own slaves killed, Jim Kizzie, a slave owner known for his brutal mistreatment of slaves. ${ }^{82}$ Another instance of slave revolt occurred when many of the 175 slaves, Ned Stone, a wealthy slave trader from Kentucky and four white assistants were transporting down the Ohio River attacked, killing all on board. ${ }^{83}$ While instances of violence among slaves toward their masters did occur, they proved quite rare.

Of course, slaves escaping to freedom by crossing the Ohio River represented an enticing form of resistance to slavery. However, many slaves also feared getting caught. The repercussions for a runaway slave often proved quite severe. Punishment for attempting to runaway usually took the form of a brutal whipping. It is difficult to ascertain how many slaves crossed the Ohio River into freedom via Kentucky. In 1850 , only 96 fugitives were reported, when Kentucky had over 211,000 slaves. A decade later, in 1860 just 119 fugitives were reported, when Kentucky's slave population numbered over $225,000 .{ }^{84}$ No true method exists to determine how many fugitive slaves went unreported. In any event, evidence suggests that slaves escaping into freedom presented a viable alternative as a means for resisting slavery.

One example of a slave willing to risk the severe repercussions for his freedom is the story of a runaway slave named Henry Bibb. Bibb risked the brutal punishment of being

\footnotetext{
${ }^{81}$ Ibid., 170-71.

82 Ibid.

${ }^{83}$ Keith P. Griffler, Frontline of Freedom: African Americans and the Forging of the Underground Railroad in the Ohio Valley (Lexington: The University Press of Kentucky, 2004), 35.

${ }^{84}$ Harrison and Klotter, A New History of Kentucky, 171.
} 
caught and made several attempts to escape from slavery. Bibb was born into slavery in Shelby County, Kentucky in $1815 .^{85}$ According to his own account, Bibb was raised in Shelby, Henry, Oldham and Trimble counties. ${ }^{86}$ In 1835, Bibb attempted his first escape into freedom. Bibb had been contracted to perform labor for a Mr. Vires in New Castle, Indiana. Bibb hoped to escape to Canada, but his master soon caught him and severely punished him with a brutal whipping. ${ }^{87}$ Bibb made a second failed attempt to escape soon thereafter, but his master caught him again and subjected him to the same harsh treatment. $^{88}$

On Christmas Day in 1837 at age twenty two, Bibb escaped into freedom. This time Bibb's motivation for escape came from his wife Malinda and their child, being owned by another slave master. Bibb crossed the Ohio River and landed at Madison, Indiana. He then boarded a steamboat destined for Cincinnati, Ohio. Bibb managed to make the journey undetected and journeyed northward into Ohio where he spent the winter.

In spring Bibb traveled back to Kentucky for his wife and child. Bibb found his wife and child and made plans to have them escape and board a steamboat bound for Cincinnati. However, they failed to arrive at the destination point and Bibb was recaptured. Undeterred, in 1839 , Bibb made yet another escape and returned to Kentucky once more for his wife and daughter. Upon his return his master captured Bibb and imprisoned him in Louisville to be resold. Once sold, the slave trader transported Bibb and his family to New Orleans and sold them at the slave market where they became

\footnotetext{
${ }^{85}$ J. Blaine Hudson, Fugitive Slaves and the Underground Railroad in the Kentucky Borderland (Jefferson: North Carolina, Mcfarland \& Company, Inc., Publishers), 131.

${ }^{86}$ Henry Bibb, Narrative of the Life and Adventures of Henry Bibb, an American Slave (New York: The Author, 1849), see 51-171.

${ }^{87}$ Ibid., 64-66.

${ }^{88}$ Ibid.
} 
separated. ${ }^{89}$ In 1845 , Bibb did manage to escape into freedom once again and attempted to find his family. According to Bibb's account he discovered his "wife was living in a state of adultery with her master. ${ }^{\text {90 }}$ In time, Bibb eventually remarried and became prominent in the national antislavery movement. ${ }^{91}$

Although the antislavery movement did not achieve its goal of emancipation, either gradual or immediate, it did keep the slavery debate alive in Kentucky. The antislavery movement in Kentucky also provided hope to the antislavery advocates in the northeast United States, who recognized that southern support was necessary to achieve their antislavery goals nationally. The actions of Kentuckians Cassius Marcellus Clay, Robert J. Breckinridge, John G. Fee and James G. Birney perpetuated the antislavery movement within the state, but they also garnered national attention for their cause. The local and national antislavery press paid attention to these men's efforts and reported them to large audiences throughout the northeast. Through their efforts and personal sacrifices to assist slaves in their escape to freedom, Delia Webster and Calvin Fairbank figured as prominent players in promoting an antislavery cause in Kentucky. More than that however, through their lecture tours throughout the northeast they made antislavery audiences aware of the slave question as it persisted in Kentucky. These efforts lent hope to their northern antislavery counterparts that resistance to slavery did and indeed could continue in a southern proslavery border state such as Kentucky. Each of the antislavery advocates made many sacrifices and risked freedom, property, personal injury and their lives for their antislavery struggle.

\footnotetext{
${ }^{89}$ Ibid., 85-162.

${ }^{90}$ Ibid., 162-163.

${ }^{91}$ Hudson, Fugitive Slaves and the Underground Railroad in the Kentucky Borderland, 132-133.
} 
In the end, the actions of each of these antislavery advocates, whether gradual emancipationist, or abolitionist, failed to achieve their goal of ending slavery within the state; but, their efforts served to continue slavery agitation within Kentucky. The fact that slavery could be debated at all in the border slave state Kentucky is testament to the fact that a significant minority of Kentuckians remained ambivalent about the "peculiar institution" and questioned slavery's practical impact on their state's economic and social condition. 


\section{CHAPTER III}

\section{WHIG IDEOLOGY AND KENTUCKY'S PROSLAVERY, PRO-UNION STANCE IN THE ANTEBELLUM ERA}

Whig ideology influenced the majority of Kentuckian's proslavery and pro-Union stance during the antebellum era. In the tradition of Kentucky's greatest politician Henry Clay, Kentucky had always first sought compromise in an effort to preserve the Union, when sectional conflict presented itself. The divisive slave issue persisted in Kentucky and the nation for decades prior to the secession crisis of 1860-61. A significant minority of Kentuckians promoted an antislavery agenda; however, the majority of Kentuckians argued slavery's practical significance for their state and remained in favor of maintaining the peculiar institution within the Commonwealth. The majority of Kentucky's proslavery proponents also favored preserving the Union. Most Kentuckians argued slavery was best protected inside of the Union, under the United States Constitution. Whig ideology influenced Kentucky's proslavery, pro-Union stance. Throughout the 1850 's, sectional conflict and discord over the divisive slave issue presented itself. The sectional controversy of 1850 , the Kansas-Nebraska Act in 1854 , the 1855-56 Know-Nothing movement, and the 1857 Lecompton Constitution controversy in Kansas, all illuminate the multifarious nature of the slave issue in the United States during the 1850's. Despite the fact the Whig Party collapsed in both the nation and in Kentucky, Whig ideology persisted in Kentucky and influenced its political 
actor's decisions regarding slavery and the Union throughout the 1850 's. During the decade, Kentucky's politicians sought sectional compromise and non-agitation on slavery in an effort to maintain the Union. Kentucky's Unionist sentiment prevailed throughout the 1850's rooted in its Whig ideology.

During the sectional controversy of 1850 , Kentucky's United States Senator, Henry Clay sought to appease both sections and reach a compromise agreement in the old line Whig tradition. In 1849 the Thirty-First Congress convened and faced the difficult challenge of addressing the slave question in the recently acquired federal territories. The territories acquired from Mexico in 1848 remained unorganized in 1849. The gold rush in California, however, attracted thousands of settlers into the territory. By 1849 , the population in California had grown to a level to merit application for statehood and the Congress divided on the slave question in the western territories. The northern congressmen demanded the recently acquired territories remain free of slavery while congressmen from the South defended their right to take their property into federal territories. As the divisive slave question persisted, talk of disunion emerged. In 1850 , Kentucky statesman Henry Clay traveled to Washington and urged the Senate to pass a compromise to appease the contending sections.

Clay supported a plan that sought to settle all sectional controversies. Clay's plan came in the form of an omnibus bill and called for the immediate admission of California as a free state, organizing territorial governments for New Mexico and Utah without the right to legislate on slavery, and reducing the size of Texas by adjusting its borders while paying its debts. The bill proposed a fugitive slave law that required slave owners to provide documentation to claim any fugitive slaves. Also, the measure required trial by 
jury if the alleged fugitive chose, in the state from which the slave had fled. In addition, the proposed measure called for the abolition of the slave trade, but not slavery in the District of Columbia. ${ }^{1}$

Upon submitting his proposal to the United States Senate Clay invoked a moderate tone stating, "I hold in my hands a series of resolutions which I desire to submit to the consideration of this body." Clay combined the eight proposals into a single omnibus bill that, according to Clay, proposed an "amicable arrangement of all questions in controversy between the free and Slave states." Clay believed the proposed bill would appease both sections and he referred to it as a "great national scheme of compromise and harmony." Clay concluded his compromise measure required neither, the free labor states or slave states to sacrifice any principle. Clay argued the compromise proposal was designed on "mutual forbearance" and derived from a sentiment of "conciliation and concession." ${ }^{2}$ Clay believed the bill required both sides to compromise equally. Fervently Clay believed this moderate approach was the most effective means for achieving his desired end of averting civil war and maintaining the Union. Clay believed the Compromise of 1850 placated both sections as concessions and gains were made on both sides. Clay's moderate approach in attempting to resolve the sectional controversy on the question of slavery was no surprise considering Clay's consistent conciliatory approach that over- time earned him the reputation as the so called Great Compromiser. Clay's Whig ideology that advocated compromise to promote sectional harmony, nonagitation on slavery, deference to the federal constitution, and preservation of Union had

\footnotetext{
${ }^{1}$ Congressional Globe, $31^{\text {st }}$ Congress, $1^{\text {st }}$ session, 948-950, 955, appendix, 902, 1463.

${ }^{2}$ Congressional Globe, $31^{\text {st }}$ Congress, $1^{\text {st }}$ session, 244-252.
} 
always promoted a sense of conciliation, and harmony in his many efforts to maintain the Union when sectional discord over the slave question arose.

Over the course of the next six months Clay set out to build public support for his proposed bill. Clay delivered numerous public speeches in an effort to arouse public opinion in support of his effort to thwart disunion. Clay appealed to the people in the free-state North to rally around his cause. Soon northerners responded to Clay's proUnion message. It soon became evident that Clay's compromise effort had overwhelming popular support. Pamphlets from around the country began pouring in endorsing Clay's proposed bill. Clay shared each with the Senate encouraging them to take action to preserve the Union, as the public demanded. At one point Clay addressed the Senate, stating, "Nineteen-twentieths, if not ninety-nine out of a hundred people of the United States . . . desire most anxiously a settlement of this question . . . and the restoration once more of peace, and harmony, and fraternity."3 Clay appealed to the public for support of his pro-Union message that incorporated the idea of unity and harmony. In the end public sentiment coalesced around Clay's message that promoted a united and harmonious effort to maintain the Union. Clay's ability to reach a wide audience and relate a message that resonated with the public compelled the Senate to take action that in the end managed to avert disunion.

After gaining popular support for his compromise bill, Clay worked with Senators from both parties in an effort to reach an agreement that would satisfy Whigs and Democrats. From February through July, Clay met in caucus each day with Senate members from both the Whig and Democrat Parties who were committed to preserving

\footnotetext{
${ }^{3}$ See, Clay to Daniel Ullman, February 2, 15, 1850, in Clay, The Works of Henry Clay, IV, (New York, 1857), 600-601; National Intelligencer, February 27, 1850; Congressional Globe, $31^{\text {st }}$ Congress, 1 st session, 1107, 1139-42, 1202-1203, 1263-1264.
} 
the Union. Clay facilitated these meetings and sought to assuage both sides, and encouraged the members to legislate a compromise agreement to resolve the slave question and preserve the Union. Clay had to work diligently to appease the disparate Senators from the Democrat Party, in particular, Democrat Lewis Cass of Michigan and Democrat from Illinois Stephen Douglas. ${ }^{4}$ Clay's ability to hold these meetings together for several months proved essential as he navigated his pro-Union message through Congress that included promoting unity and harmony despite the disparate interests of members within the group.

Clay recognized that to achieve any effort at compromise required diligent work on his part to facilitate the agreement. Clay realized the importance of working with often fragmented pro-Union members of the Senate as well as with southern senators opposed to any concessions made regarding slavery. After several months of negotiations and amid stiff resistance from proslavery southern Senators, Clay turned his proposed omnibus bill over to the Committee of Thirteen. The Committee of Thirteen was comprised of both northern and southern senators that for several months, considered, debated, and negotiated Clay's proposed bill until finally an agreement could be reached. In the end, perhaps the most important strategy employed by Clay was submitting his compromise proposals to the Committee of Thirteen. Clay's compromise bill failed to gain majority support and was not passed as an omnibus package. However, following several months of debate the proposals contained in the original bill passed separately. Owing in no small part to several senators, not the least of whom was Democrat Senator Stephen A. Douglas, the passage of Clay's compromise proposals reflected Clay's

\footnotetext{
${ }^{4}$ See, Robert V. Remini, Henry Clay: Statesman for the Union (New York: W.W. Norton \& Company, 1991), 732-735.
} 
indomitable spirit and cooperative nature. Clay failed as a leader to push through his compromise measures in the beginning. Clay had to make many concessions that included submitting his compromise proposals as an omnibus package to the Committee of Thirteen and negotiate with pro-Union caucus members as well as with opposition southern senators in an effort to reach a compromise that would resolve the slave question and save the Union. In the final analysis, although Clay was not solely responsible for passing the compromise measures in 1850 that averted disunion, he above all others, worked diligently to achieve his objective. Clay's defense of the Union, his tireless efforts to engage in debates with senate colleagues, and his impassioned speeches that aroused public opinion all set Clay apart as the man most responsible for the Compromise of 1850 . In the end Clay's compromise position reflected his Whig ideology that formed an intrinsic part of his political being, the fiber of which can be found interwoven throughout the fabric of his political career.

The Compromise of 1850 also received much attention in Kentucky. Clay encouraged Whig legislators in Kentucky to arouse Unionist sentiment within the Commonwealth. Clay believed strong state support for compromise and therefore the Union existed in Kentucky and it would encourage and bolster support for his compromise proposals throughout the nation, particularly the South. In a December 22, 1849 letter to Leslie Combs, Clay declared, "You are the man to do it." Clay encouraged holding meetings to "express in strong language their determination to stand by the Union." ${ }^{, 5}$ Governor John J. Crittenden joined Clay in his efforts to rally public support for the Union in his January 1850 address to the state legislature. Crittenden declared Kentucky had no "thought against the Union." According to Crittenden, Kentuckians understood the importance of

\footnotetext{
${ }^{5}$ Clay to Combs, 22 December 1849 and 22 January 1850, Clay Papers, 635-36, 651;
} 
maintaining positive economic relations with the Union. Disunion would prove disastrous to the state's commerce and economy. Crittenden invoked a pro-Union sentiment in his address to the state legislature stating, "Dear as Kentucky is to us, she is not our whole country." Crittenden espoused a pro-Union sentiment that he believed reflected the state's majority view. Crittenden remained confident that the state legislature would maintain its loyalty to the Union if faced with the decision to secede.

The Whig press within the state worked to express a strong pro-Union sentiment as well. John D. Prentice, editor of the Louisville Journal declared the, "UNION MUST BE PRESERVED."7 Prentice argued that the Union must be preserved in order to protect slave property. The fact that Prentice equated Unionism with slave protection undermined any accusation of sectional radicalism by pro-secession proponents. Thus, Kentucky's pro-Union position was unique. Kentuckians believed the United States Constitution was sufficient to protect their right to hold property in persons and, therefore, it was not necessary to secede from the Union. Many hoped that other states in the proslavery South would agree and adopt Kentucky's position; thus, averting civil war.

Despite the large Whig majority a significant state's rights Democrat minority in the Kentucky House and Senate existed therefore, efforts to pass pro-Union resolutions were met with resistance. Beginning in January the state legislature considered many resolutions regarding the slave question. Whig William Miller introduced a resolution in the House that resolved that the Commonwealth would always be "ever true and faithful to the Union." According to Miller people of a federal territory could choose to adopt a state constitution that either included or prohibited slavery. He argued, therefore, that

\footnotetext{
${ }^{6}$ House Journal, 1849-50, 28-9.

${ }^{7}$ House Journal, 3 January 1850.

${ }^{8}$ House Journal, 1849-50, 35.
} 
California should be admitted to the Union. Democrat James P. Bates of Barren County accused "Northern fanatics" of attempting to "deprive [Kentuckians] of a fair and equitable participation" ${ }^{\prime 9}$ in the recently acquired territories from Mexico. The resolutions submitted by Bates claimed that territory acquired in the Mexican Cession in 1848 was "common property" $" 10$ and it was necessary to defend slave owners right to take their slave property into these federal territories. The pro-Southern and state's rights view espoused by many state Democrats was evident in the rest of Bates resolution. Bates did not deny that Kentuckians would support the Union, but also asserted Kentuckians would, "at all hazards ... maintain and defend our own domestic institutions." While Miller had expressed the Whigs' "full and perfect confidence" in the state's senators to handle the matter, Bates declared the House possessed the "undoubted right to instruct" the state Senate to vote against governments that proposed to ban slavery in federal territories south of the Missouri Compromise line. Democrat John C. Breckinridge of Fayette County advocated leaving the decision regarding slavery to the people of the territories, but recognized that Kentuckians favored extending the Missouri Compromise line west to the Pacific. Breckinridge's resolutions acknowledged the Commonwealth did not prefer disunion, rather, Kentuckians preferred to rely on the federal Constitution for a "just and equal settlement" Therefore, although Whigs held a majority in the Commonwealth, the Democrats were able to pose a significant challenge to their positions on the slave issue. The Democrats resolutions offered to instruct Kentucky's federal Whig Senators Henry Clay and John Underwood in an effort to restrict the actions they could take or otherwise force their

\footnotetext{
${ }^{9}$ House Journal, 1849-50, 42.

${ }^{10}$ Ibid.

${ }^{11}$ Ibid., 35, 42, 68, 103-4, 117-25.
} 
resignations. In addition, Democrats promised only conditional allegiance to the Union, whereas, the Whigs had always pledged unconditional loyalty.

In the state Senate, resolutions were more moderate and perhaps illuminated potential divisions within the Whig party in the Commonwealth. State Senator John W. Russell introduced a resolution that proposed, that to abolish slavery in the District of Columbia would undermine the "rights and security" 12 of citizens, sever ties with both Virginia and Maryland and would be an unnecessary "cause of alarm" to the proslavery South. The Whigs, however, continued their Unionist sentiment, declaring that any settlement of the sectional controversy would not be sufficient grounds for destroying the Union. Whig Senator George W. Barbour called for more radical measures, by instructing United States Senators Henry Clay and Joseph Underwood to oppose efforts to interfere with slavery in the federal territories and in the District of Columbia. Barbour, however, maintained his support and fidelity for the Union. The Senate resolutions were sent to the Committee on Federal Relations, which was to manufacture a set of agreeable resolutions to present to the full House and Senate. The contending views presented in the House and Senate among Whig legislators highlighted the internal divisions within the Whig Party in Kentucky as how to reach the best possible solution to the sectional crisis.

On the national political scene the Whigs risked being divided as well. Henry Clay's plan to resolve the sectional controversy stood in sharp contrast to fellow Whig, President Zachary Taylor's plan. While both men sought to maintain the Union they each proposed different means to achieve the same end. Taylor's plan supported the admission of California as a free state as well as the admission of both the New Mexico and Utah lands thus circumventing the territorial stage completely. In this manner the slave question

\footnotetext{
${ }^{12}$ Senate Journal, 1849-50, 20-1, 91.
} 
could be removed from the Mexican Cession entirely. Clay's plan dealt with slavery. Although Clay agreed with Taylor that California should be admitted as a free state, his plan called for organizing the rest of the Mexican Cession as the federal territories of New Mexico and Utah, thus, leaving to the residents of each the slave question. Clay's plan also addressed slavery where it already existed, by calling for the abolition of the slave trade in the District of Columbia, and strengthening the fugitive slave law. Many Whigs however, supported President Taylor's plan while Clay received much support from the Democrats. Many within the Whig Party accused Clay of splitting the party by breaking with the administration for his own political gain and as perhaps revenge for the 1848 presidential election.

In Kentucky, a few were alienated by Clay's actions. In a February 51850 , letter to Governor Crittenden, Secretary of State John M. Clayton wrote, "If there is any spunk in Kentucky she ought to call him home in case he breaks the pledge to the Legislature" to support President Taylor. ${ }^{13}$ Many in the press criticized Clay as well. John W. Finnell, editor of the Frankfort Commonwealth had always admired and supported Clay now Finnell declared he could not support Clay against the "veriest loco in the Union."14 In Kentucky, Clay still had many supporters. In 1848, Governor Crittenden and his supporters backed Taylor against Clay. In 1850, however, most Kentuckians supported Clay's plan to solve the sectional controversy. The inability of the national Whig Party to reconcile the differences between Taylor and Clay caused a split in the party on a major issue and allowed the Democrats an opportunity to garner support for their proslavery,

\footnotetext{
${ }^{13}$ John M. Clayton to Crittenden, 5 February 1850, University of Kentucky Special Collections.

${ }^{14}$ John W. Finnell to Brown, 28 April 1850, Orlando Brown Papers.
} 
pro-state's rights views that undermined the Whigs ability to confront and resolve a major issue with a united stance.

Most Whigs in Kentucky stood behind Henry Clay's proposal that reflected the proUnion, but also strong southern rights sentiment held by a majority of Kentuckians. Despite the fact the national Whig Party split over which approach was best to resolve the sectional controversy, most Northern Whigs supported President Taylor's proposal. Therefore, it was unlikely that Kentucky Whigs would acquiesce to the northern Whigs demands regarding slavery in the federal territories. Based on their support for Henry Clay's proposal it was much more likely that Kentucky Whigs would give their full support to the southern Whigs or perhaps, even Democrats, particularly pro-Union Democrats, if necessary. In the midst of the sectional controversy of 1850 it was clear division existed within the Whig Party. It was also clear that Kentucky Whigs were unwilling to forgo their constitutional right to hold property in persons and remained firm in their commitment that the Constitution best protected that right. In addition, Kentucky Whigs persisted in their belief that Congress did not possess the right to interfere with slavery in the territories or where it already existed. Therefore, although internal divisions existed among the Whig Party nationally, and to a degree even among Kentucky Whigs, in the end Kentucky Whigs held to their strong proslavery southern rights view, but also maintained their loyalty to the Union. This strand of Whig ideology prevailed in Kentucky in 1850 and persisted throughout the coming decade and through the beginning of the Civil War.

Despite losing the Governor's race by a narrow margin in 1851 , the Whig Party in Kentucky won most of the rest of the state ticket and remained strong through 1854 . 
During this time, however, sensing the mood of the Kentucky voters, Kentucky Whigs shifted their political strategy back and forth between an emphasis on promoting Unionism and protecting slavery, in an effort to appease the Kentucky electorate at any given point in time. Democrats accused the Whigs of vacillating between the issues only as a means of garnering votes. The critics charged the Whigs with not having any principles and offered their shifting positions on the issues of Union and slavery as the evidence. This shifting political strategy employed by the Whigs also cost them votes with each change as some supporters of one issue would defect from the Party once the Whigs shifted their focus to the other issue. Over the course of a few years this dynamic weakened the Whig Party as more supporters were lost than gained. Also many voters began to buy into the Democrats accusations that the Whigs were devoid of any principles as evidenced by their shifting between the issues.

While the 1854 Kansas-Nebraska Act posed devastating consequences for the national Whig Party, it weakened the Whig Party in Kentucky. Initially, the bill gained much support from the Whigs in Kentucky, who believed the bill contained principles that favored the South. Also, many Whigs thought supporting the bill would insulate their party from Democrat assaults on the slavery issue. Once northern popular opinion was expressed, however, many Kentucky Whigs had reservations about supporting the bill due to the threat it posed for sectional harmony.

Many Kentucky Whigs agreed with the principle of popular sovereignty, perhaps, due more to their belief that it was still better to allow the people of the territory to decide the question of slavery than to ban slavery altogether. Kentucky's United States Whig Senator Archibald Dixon introduced an amendment to the Kansas-Nebraska Act 
repealing the Missouri Compromise of 1820. According to Whig editor George D.

Prentice of the Louisville Journal, Kentucky Whigs could support the proposed measure, so long as it could be accepted by, "common consent, as an ultimate and permanent adjustment of the whole question of slavery[.] ${ }^{15}$ According to Prentice, however, the North did not desire to change the Missouri compromise line. The Missouri Compromise of 1820 and the Compromise of 1850 were, as noted by Prentice "extra-constitutional and strictly invalid," ${ }^{16}$ but had been necessary to achieve sectional peace and avert civil war. Since the North had always abided by the agreements the South was likewise obligated, by honor, if nothing else to adhere to the compromise agreements. It was well understood revisiting slavery would once again bring the only issue that threatened sectional peace to the fore. While, Prentice agreed with the popular sovereignty principle contained in the Kansas-Nebraska Act and Dixon's proposed amendment to the bill, he feared neither would appease both sections. Thus, the Kansas-Nebraska Act could only result in renewed agitation of the slave question that threatened the future of the Union. Many other Whigs advocated for the Kansas-Nebraska Act and Dixon's amendment for different reasons. Support for the bill showed their commitment to preserving slavery. Also, by showing their proslavery stance, the Whigs placed the Democrats on the defensive as they could no longer evade their position on the slave issue. Whigs in the Kentucky House of Representatives devised resolutions that called for repeal of the Missouri Compromise. By banning the slavery restriction Kentucky Whigs declared that Congress did not possess the authority to ban slavery or define property. According to the House Whigs reasoning, only the residents of a territory had the power to decide the

\footnotetext{
${ }^{15}$ Journal, 14 January $1854,2$.

${ }^{16}$ Ibid., 31 January 1854, 2.
} 
matter of slavery at the time of forming a state constitution. Therefore, the Kentucky House Whigs rejected Douglas' notion that residents of a federal territory possessed the power to decide the slave question. In the minds of Kentucky House Whigs only a state constitution could restrict slavery. The majority of House Whigs realized that their best political strategy regarding slavery included supporting the repeal of the Missouri Compromise. While Kentucky Whigs agreed with Douglas that the federal government lacked the power to regulate the institution of slavery, they departed from Douglas' popular sovereignty view, by asserting territorial residents likewise did not possess the power to do so.

Most Kentucky residents and legislators supported the Kansas-Nebraska Act. Democrats supported the bill because it placed the power to decide the slave question in the hands of the territorial residents. Eight out of nine Kentucky Congressmen voted for the bill, including Senator Dixon. Senator Thompson abstained from voting on the measure, but had been in favor of other earlier measures that friends of the bill had supported, that included rejecting a proposal that would have allowed territorial residents to prohibit the institution of slavery. ${ }^{17}$

Although the Kansas-Nebraska Act did not pose the dire consequences for Kentucky's political system as it had for the North's, the act did weaken the Whig Party in the state. Kentucky Whigs support for the bill reflected their proslavery stance. The Whigs in Kentucky had been successful in shifting their emphasis between Union and slavery from 1850 through 1853 . In 1854, the Kentucky Whigs divided between the two issues. Democrats had long accused the Whigs of shifting their position between Union and slavery only in an effort to garner as many votes as possible. Since 1853 the Kentucky

\footnotetext{
${ }^{17}$ Congressional Globe, 33 Cong., 1 session, 343, 421, 519-20, 532, 1254.
} 
Whigs had heralded defense of slavery as the issue of primary importance in their Commonwealth. In light of the sectional discord caused by the Kansas-Nebraska Act throughout the North many in the Whig Party in Kentucky were compelled to once again proclaim Union as their primary cause for concern.

The emergence of the Know-Nothing movement in the nation and Kentucky also served to weaken the Whig Party within the Commonwealth; however, most Kentucky Know-Nothings were former Whigs, thus, Whig ideology endured. The popularity of the Know-Nothings in 1854-55, convinced the Whig Party leaders not to run a candidate and forgo the 1855 state elections. Unlike many Northern Whigs, who lost much support from the voters first, then their leaders; in Kentucky, the leaders made the decision to forgo the election altogether from the top down and the loyal voters followed. ${ }^{18}$

In 1855 , the rise of the Know-Nothing Party in the North and Kentucky spelled the end of the Whig Party. In Kentucky, the Know-Nothings won convincingly in the statewide elections in 1855 , including winning six of ten congressional seats, electing a majority in the state legislature, and taking all of the state offices, that included electing Know-Nothing candidate Charles S. Morehead governor. In Kentucky, however, the Know-Nothings achieved little over the four years the party existed within the state. The American Party's most significant achievement was ending the Whig Party within the Commonwealth. ${ }^{19}$

The American Party rose to prominence in light of the anti-Catholic and antiimmigrant sentiment that had emerged throughout the nation. Because the 1852 Whig

\footnotetext{
${ }^{18}$ See, Michael F. Holt, "The Mysterious Disappearance of the American Whig Party," in Political Parties and American Political Development from the Age of Jackson to the Age of Lincoln (Baton Rouge: Louisiana State University Press, 1992), 239-41, 246-51.

${ }^{19}$ See, Michael F. Holt, "The Politics of Impatience: The Origins of Know-Nothingism," in Political Parties, 265-90.
} 
Presidential candidate Winfield Scott courted Catholics and foreign-born voters in an effort to pull Democrat votes, made the new American Party a viable alternative for those who no longer trusted the Whigs. In Kentucky many feared the anti-slavery sentiment of foreign-born immigrants. In Louisville, nativism became popular as many opposed the immigrant attacks on Kansa-Nebraska and slavery. Know-Nothingism became popular throughout the Commonwealth, as many Kentuckians, and in particular Whigs, agreed with the proslavery position advocated by the movement. The Know-Nothing movement held most prominence in Louisville, however, as many residents disagreed with the city's large immigrant population's anti-slavery stance.

The rise of the Know-Nothings in Kentucky can also be attributed to the fact that many people in the Commonwealth sought a new national party because the Whigs had been severely weakened and the nation and could no longer offer voters a stable two party system. In the Commonwealth, the Democrats charge that the Whigs lacked principle pointing to their shifting emphasis between Unionism and slavery resonated with voters. However, many still were not willing to abandon their Whig ideology to join the Democrats. Thus, the new American Party offered voters a new national party that was unified behind a single message.

The American Party's platform fit well with most Whigs who shared a similar ideology. Like Whigs, the American Party in Kentucky advocated compromise agreements to promote Unionism on sectional controversies and believed the divisive slavery issue was not a matter that should be addressed in national politics. Although the American Party could claim independence from either major party, the Democrats or Whigs, many of their members in Kentucky were in fact former Whigs. 
As the Whig Party collapsed in Kentucky, the Know-Nothing Party emerged. The old line Whig ideology that advocated preservation of the Union and protection of slavery did not cease to exist but endured. Three former prominent Whigs- - Robert J. Breckinridge, George D. Prentice and Garret Davis- - all joined the efforts of the American Party. In the border slave state of Kentucky the Know-Nothings were more concerned with sectional discord over the slavery issue than with immigrants or to an even lesser degree any disdain for Catholics. Kentucky Know-Nothings, like the old Whig Party in the state, maintained their strong belief in the Union and the protection offered to slaveholders under the federal constitution. George D. Prentice who had earlier argued against nativism, in 1855 argued for the movement as one of its most influential members in the Commonwealth. Prentice accused the Northern states of trying to violate the rights of the states by making efforts to erode the constitutional protection for slaveholders. Many accused the Know-Nothings of promoting abolitionism. Editor of the Louisville Journal, George D. Prentice defended the KnowNothings against such claims writing, the American Party was, "the true, the formidable, and the only... antagonist of abolitionism. ${ }^{20}$ According to Prentice the American Party in Kentucky had taken on the role as protector of property rights for slaveholders. ${ }^{21}$

The Know-Nothings in Kentucky, unlike their Northern counterparts, united behind the American Party's national platform that discouraged agitation on slavery and that called for preserving the Union. The fact the American Party supported the Union and believed slavery should not be a matter dealt with by the federal Congress implied support for the Kansas-Nebraska Act. The absence of an explicit anti-Nebraska position

\footnotetext{
${ }^{20}$ Louisville Journal, December 30, 1854.

${ }^{21}$ Ibid., March 20, 1854.
} 
alienated many Know-Nothings in the North, particularly in New England. Kentucky Know-Nothings recognized that an anti-Nebraska sentiment would only serve to alienate the South, thus promoting sectional discord. Kentucky Know-Nothings, many of whom were former Whigs, continued to reason that the federal government did not possess the authority to encroach a state's right to allow its residents to own property in persons. Kentucky Know-Nothings, like former Kentucky Whigs, believed the federal constitution guaranteed the right to hold property in persons and remained a sufficient protector of those rights. Therefore, Kentucky Know-Nothings adopted the same strategy of the old line Whigs that advocated for non-agitation of slavery and preservation of the Union.

Kentucky Know-Nothings response to national events that included the 1857 Lecompton Controversy in Kansas illuminated the American Party's ideology regarding slavery and the role of the federal government regarding the slave issue. State Democrats whole heartedly supported the Lecompton Constitution and supported the admission of Kansas into statehood under the document. In the Kentucky House of Representatives Democrats voted by a party line vote 55-34 to pass a resolution encouraging the state senate to "favor the immediate admission" of Kansas under the Lecompton Constitution. The Democrats argued to admit Kansas immediately would "terminate all external agitation" on the slave question. ${ }^{22}$ The American Party in the Commonwealth took a different position on Kansas. Know-Nothings in the state desired Kansas to be a slave state, but not at the expense of the majority will of Kansans. The Know-Nothings in Kentucky believed the Lecompton Constitution usurped the majority voice of settlers in Kansas and was unconstitutional. Many Know-Nothings also believed that if Kansas was forced to accept slavery against the majority's will, the state would embrace free-soil

${ }^{22}$ House Journal, 1857-58, 173-4, 300. 
more fervently than many northeastern states had. The Kentucky State Senate passed resolutions conveying their sentiment that read Kansas "ought not to be admitted, if Congress is satisfied that the constitution she presents is not approved by a majority of all the legal voters of the territory." 23 The respective parties contending views on Lecompton continued throughout 1858 as neither side was willing to make concessions to the other.

Throughout 1858, heated rhetoric and debate continued among the Democrats and Americans in Kentucky. Although only one statewide race was on the election ballot, each party treated the state election for the office of clerk of the Court of Appeals as a referendum on national issues. Democrats met in convention in January and passed resolutions supporting President James Buchanan's endorsement for the Lecompton Constitution. Democrats continued to berate Americans for their anti-Lecompton stance, calling anyone who opposed admission of Kansas as a slave state under the Lecompton Constitution a traitor. All Eight Democrat congressmen voted for the admission of Kansas under the Lecompton Constitution. Know-Nothing Senator and former Whig John J. Crittenden endured much criticism from Democrats in the state for voting against Lecompton. $^{24}$

The American Party viewed the Lecompton controversy as an opportunity to form a national anti-Democrat organization. In light of Senator Stephen Douglas's break with his own party over Lecompton, Americans recognized that many Douglas Democrats, Know-Nothings, and old line Whigs, could combine to form an effective anti-Democrat coalition. According to the American Party, the South would not benefit from Kansas

\footnotetext{
${ }^{23}$ Senate Journal, 1857-58, 208-9, 369-71, 389-93.

${ }^{24}$ Congressional Globe, $35^{\text {th }}$ Congress, $1^{\text {st }}$ session, $1437-8,1545,1590,1905-6$.
} 
having slavery forced upon them. Senator Crittenden opposed the Buchanan administration's support for Lecompton and voted against the admitting Kansas as a state under the document. Crittenden introduced his own proposal to resolve the Lecompton controversy. Crittenden's proposal called for allowing Kansans to vote on their own constitution in a free and fair referendum. ${ }^{25}$ Thus, Crittenden's proposal appealed to Douglas Democrats, former Whigs, and Republicans. As a result of Senator Crittenden's actions on Lecompton many former Whigs in the Commonwealth began to rejoin the American Party after drifting to the Democrats post 1855 . Crittenden rooted his stance on Lecompton in his old line Whig ideology that sought compromise first on matters of sectional controversy and believed the Constitution and Union remained paramount to all other objectives. The Know-Nothings did not form an effective national organization due to the fact that many Republicans were not willing to forgo their party loyalty for one that was more sympathetic to slavery. Thus, despite the initial success in Kentucky, the Know-Nothings could not remain a viable party option in national politics and thus, faced a similar fate the Whigs had already met.

In the end, the actions of Kentucky's state and federal Know-Nothing legislators laid the ground work for ushering in a new era of politics in the Commonwealth. By adhering to the old line Whig ideology that advocated compromise on sectional matters, nonagitation of slavery, and the preeminence of the Constitution and Union, the KnowNothings in Kentucky appealed to varying elements within the state's electorate that allowed a new coalition to form and develop. As a result, a new party emerged that could challenge and defeat the Democrats in the state, the new Constitutional Union Party. During the election of 1860 and through the secession crisis Whig tenets continued to

\footnotetext{
${ }^{25}$ See, Congressional Globe, 35 Congress, 1 session, 1153-59.
} 
endure throughout the Commonwealth. After the death of the Whig Party in the nation and in Kentucky during the aftermath of the 1854 Kansas-Nebraska Act the actions of Know-Nothings in the state continued to promote Whig ideology that had become ingrained into the minds and political beings of the majority of Kentuckians. The power of Whig ideology served as the impetus for a majority of Kentuckian's political action throughout the 1850's and continued to form the basis of most Kentuckian's belief that preservation of the Union remained the best means to maintain slavery for their state. 


\section{CHAPTER IV}

\section{KENTUCKY'S DILEMMA: THE POLITICS OF UNIONISM AND SLAVERY IN THE ANTEBELLUM ERA}

In antebellum Kentucky the state legislature supported Kentuckian's legal right to own property in persons pointing to both the Kentucky and United States Constitution as their justification to do so. The Kentucky legislature also espoused a nationalist outlook that advocated economic ties with both sections; but, increasingly with the North. As a result Kentucky's political actors consistently advocated compromise measures at various points in time, in order to appease both sections when sectional conflict loomed. Politically, Kentucky was a pro-Whig state until that Party collapsed in 1855 . The Whig ideology that had been advocated by long time Kentucky statesman and United States Senator Henry Clay influenced a majority of Kentucky's national political actors as well as its state legislators during the period from the state's third Constitutional Convention of 1849-1850 through the beginning of the United States Civil War in 1861. This chapter examines and analyzes the actions of the state's political actors during this crucial period from 1849-1861 and considers the impact Whig ideology had on shaping a majority of Kentuckians proslavery views and Pro-Union sentiment.

Kentuckians had been nationalist in their outlook. They supported the Union for economic, constitutional and moral considerations. In the face of national crises, Kentucky first sought compromise in an effort to preserve the Union. In the crucial era 
from 1849 through the secession crisis and the beginning of the Civil War Kentuckians debated the slave question within the Commonwealth. The legislative actions in this period reflect the pro-slavery and pro-Union sentiment held by a majority of Kentuckians. During the secession crisis most Kentuckians continued to believe in their right to hold property in persons. However, this did not mean they likewise believed it necessary to secede from the Union in order to protect that right. Kentuckians pointed to the United States Constitution as the basis for their right to own slaves. Thus, the majority of Kentuckians believed the best way to protect the right to own property in persons was to maintain their loyalty to the Union. In the end, Kentuckian's nationalist outlook, rooted in Whig ideology influenced the majority of Kentuckians' pro-slavery and pro-Union sentiment.

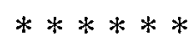

Kentucky's third constitutional convention convened in late 1849 and lasted into early 1850. Both of the state's major political parties viewed the convention as necessary to address many key issues that affected both parties and their respective constituents. Prominent among the topics under consideration was the persistent and divisive slavery issue. The slavery debate figured prominently among the topics of discussion with people throughout the Commonwealth as the campaign for delegates to the constitutional convention suggested. A significant minority of antislavery advocates within the state sought to reform slavery. On the other hand, many more proslavery proponents existed who sought not only to maintain the institution of slavery in the state but, who also sought to strengthen the new constitution to ensure the perpetuation of slavery in Kentucky. 
The election for delegates to the constitutional convention in 1849 , shows that antislavery advocates were present in Kentucky. The election results reveal antislavery men garnered a significant number of votes throughout the state. However, the known emancipationist candidates won only two seats at the convention. Silas Woodson was elected to represent Knox and Harlan Counties, located in the Appalachian Mountain Region in extreme southeast Kentucky and, Ira Root, who was elected in Kenton County, located directly across the Ohio River from Cincinnati in northern Kentucky. In Knox and Harlan Counties Woodson received 74.1 percent of the vote and Root garnered 59.9 percent of the vote total in the city of Newport. Gradual emancipationists ran strong races in other areas of the state as well. In Louisville, emancipationists received 45.2 percent of the total votes cast. In Logan County, located in Western Kentucky emancipationists received 45.5 percent of the votes and in Crittenden County, also located in Western Kentucky, they gained 42.3 percent of the total votes cast. Election results are known for sixty of the one hundred Kentucky counties. In many counties the convention delegate contests were nonpartisan, as both parties sought to conceal their respective candidate's position on the contentious slave issue, thus, increasing their chances for victory, depending on public opinion on the matter in their respective county. While these numbers make it difficult to ascertain the exact figures for the convention election statewide, it is known that emancipationist candidates received 35.1 percent of the votes cast in the sixty counties where election statistics were recorded. The total number of votes received by known emancipationist candidates in the sixty counties that kept election statistics varies from 10,394 to 14,801 . However, multiple sources are closer to the latter estimate. If these figures are accepted, one can estimate that 
approximately 9.7 percent of the votes cast went to emancipationist candidates statewide. ${ }^{1}$

Kentucky's third constitutional convention dealt with many issues; however, slavery was linked to most of the topics of discussion considered by the one hundred delegates elected to serve at the convention. Convention delegates considered issues such as redistricting, in an effort to reapportion votes that was thought to benefit each respective party's candidates in state legislative elections. Also delegates considered representation at the federal level and each side sought to gerrymander districts to benefit their party thereby increasing their representation in the federal congress. Democrats became particularly interested in redistricting as they argued the Whigs had previously gerrymandered districts to enhance their political advantage in the state legislature and the federal congress. The Democrats had not won a statewide electoral contest in fourteen years. Another point of contention for Democrats was the fact that most public officials were appointed by the governor and held life time appointments. The Democrat Party remained critical of the electoral system under the Second Kentucky Constitution arguing the Whigs had through their majority, manipulated the system in a way that gave them monopoly control over the state's public offices. Impassioned debates occurred concerning the proper sphere of the state's right to govern; particularly, regarding slavery. In each of these debates the practice of slavery figured common among them.

\footnotetext{
'See, Harold D. Tallant, Evil Necessity: Slavery and Political Culture in Antebellum Kentucky (Lexington: The University Press of Kentucky, 2003), 149; Louisville Examiner, August 11, 18, 1849; Louisville Journal, August 9, 10,11, 1849; Louisville Examiner, March 24, May 5, 19, 26, June 16, 23, 1849; Clay Harlan to Orlando Brown, August 14, 1849, Orlando Brown Papers, Filson Historical Society [hereafter cited as FHS]; Samuel F. Miller to Sir, April 16, 1867, Charles Lanman Papers, FHS. For varying estimates of actual votes cast for emancipationist candidates see, Wesley Norton, "Reaction in the Religious Press to the Campaign for Delegates to the Kentucky Constitutional Convention in 1849," Register of the Kentucky Historical Society 60 (April 1962) 151; See also, Kentucky, Report of the Debates and Proceedings of the Convention for the Revision of the Constitution of the State of Kentucky, 1849 (Frankfort, Ky.: A.G. Hodges, 1849) 114, 336-37.
} 
Often, debates on voter apportionment or representation in the legislature revolved around the slavery issue. Among the topics of discussion considered by the delegates at Kentucky's third constitutional convention was the slavery issue. As the convention progressed it became clear that a majority of the convention delegates were proslavery proponents. By convention's end proslavery advocates not only supported slavery as it then existed in the state; but, in fact, strengthened the state constitution to ensure the perpetuation of the peculiar institution in the Commonwealth. ${ }^{2}$

Prior to the election of convention delegates in August 1849 proslavery proponents held a convention of the so called "Friends of Constitutional Reform" in February 1849 in an effort to establish a distinctive political organization. The primary goal of that convention was to ensure the voters of Kentucky that slavery abolition was not the goal of the state's third constitutional convention. According to convention delegates the new constitution would address many other issues that had been on the mind of many white Kentuckians for some time and it would make state government more responsive to meeting those concerns. Specifically, the convention of the Friends of Constitutional Reform called for better representation of the state's white citizens, by reducing the number of appointive offices, eliminating life tenure for public servants as well as addressing other key concerns such as, placing limits on the legislature's ability to contract state debt, paying public debt in a timely manner and investing in a solid public education system. While the Friends of Constitutional Reform operated under the guise of these other prominent issues, it became clear the primary goal of the Friends of

\footnotetext{
${ }^{2}$ See Carl Fields, "Making Kentucky's Third Constitution," unpublished Ph. D. dissertation, University of Kentucky, 1951, 191-92; Harry A. Volz, "Party, State, and Nation: Kentucky and the Coming of the American Civil War," Ph.D. diss., University of Virginia, 1982, 69-75. See also, Tallant, Evil Necessity, 137.
} 
Constitutional Reform was to reassure the proslavery voters of Kentucky and any opponents on the slave question that slavery would not be interfered with and would continue to exist within the state. In fact, the convention devoted approximately half of its platform to formulating a proslavery agenda. ${ }^{3}$

The Friends of Constitutional Reform organized their county conventions around the organization's proslavery stance encouraging members to seek delegates from both of the state's major political parties, the Democrats and also the Whigs. Accordingly, proslavery advocates throughout the state began to seek nominees for delegate candidates for the state convention. In many counties throughout the state the convention tickets included members from both parties. Counties with large populations elected more than one convention delegate; thus, proslavery proponents worked hard to ensure bipartisan tickets were elected in these areas. The state's most populated counties, Jefferson, Fayette, Madison and Franklin all elected bipartisan tickets to serve as delegates at the constitutional convention. The Friends of Constitutional Reform sought to rid the constitutional convention of partisanship by choosing not to promote the many divisive issues that likely would be addressed in the constitutional convention and instead focused on the one key issue that delegates from both parties could agree on--the slave issue. This strategy suggests the primary goal of the convention for the Friends of Constitutional Reform was to preserve slavery within the state. In fact, the Friends of Constitutional Reform devoted at least half of their platform to the slavery issue.

\footnotetext{
${ }^{3}$ See, Louisville Examiner, February 17, 1849; Harry A. Volz, "Party, State, and Nation: Kentucky and the Coming of the American Civil War," Ph.D. dissertation, University of Virginia, 1982, 72; C. Fields, “Kentucky's Third Constitution," 163-165. See also, Louisville Examiner, February 3, 10, 1849.
} 
According to the minutes of these meetings all of the proslavery resolutions passed unanimously. ${ }^{4}$

The vast majority of Kentucky Whigs maintained their constitutional right to hold property in persons and favored a convention platform that called for no interference with the institution of slavery as it then and always had existed in the Commonwealth. This view stood in contrast to Whigs' national position on slavery. Even Kentucky Senator Henry Clay had been a long time advocate for gradual emancipation and colonization. Clay had called for emancipation when he campaigned for delegates to serve at the state's second constitutional convention fifty years prior. Faced with the third state constitutional convention Henry Clay once again spoke out in favor of an antislavery agenda and offered a proposal of post nati emancipation and colonization. According to this plan all slaves born after a certain date would be manumitted upon reaching adulthood. Henry Clay's emancipation plan was not a radical abolitionist plot to end slavery abruptly in the state and thus did not compare to John G. Fee's abolitionist agenda. Clay's plan was also a much milder form of emancipation than either Robert $\mathbf{J}$. Breckinridge's or Cassius Clay's emancipation plans. However, despite the milder form of Henry Clay's post nati emancipation and colonization proposal, as well as his reputation and popularity in the state, Whigs throughout the Commonwealth rejected outright Clay's proposed plan. Many even called for Clay's resignation from the United States Senate. ${ }^{5}$ For Kentuckians, particularly those from within his own party to

\footnotetext{
${ }^{4}$ See Louisville Examiner, February 3, 10, 17, 1849; Volz, "Party, State, and Nation," 74-75; Hambleton Tapp, "Robert J. Breckinridge and the Year 1849," Filson Club History Quarterly 12 (July 1938), $136-138$. ${ }^{5}$ See Clement Eaton, Henry Clay and the Art of American Politics (Boston: Little, Brown, 1957), 135-36; Glyndon G. Van Deusen, The Life of Henry Clay (Boston: Little, Brown, 1937), 419-20; Robert V. Remini, Henry Clay: Statesman for the Union (New York: W.W. Norton \& Company, 1991), 179-180. Richard L. Troutman, "The Emancipation of Slaves by Henry Clay," Journal of Negro History 40 (April 1955), 159174. For Kentuckians response to Henry Clay's plan for emancipation, see Jacobs to McLain, March 11,
} 
denounce the longstanding and powerful Henry Clay suggesting just how divisive the slave issue was in the Commonwealth. It further illuminates the resolve that Kentucky Whigs showed regarding their constitutional right to hold property in persons. The majority of Kentucky Whigs unlike their national counterparts were unwilling to accept any change--either immediate or gradual-- concerning the practice of slavery in their state.

Proslavery proponents in the Kentucky state legislature reiterated their position leading up to the third state constitutional convention by securing the repeal of the Nonimportation Law of $1833 .^{6}$ Interest in repealing the Law of 1833 had grown during the 1840 's as demand for slaves increased, particularly in the southwest portion of the state, where larger farms reminiscent of the large plantations in the Deep South were prevalent. Also, increased demand for slaves throughout the South awakened many to the prospects that bringing more slaves into the state would have for those involved in the lucrative slave trade. In 1849 , however, the chief concern for the proslavery legislators was that the antislavery men would advocate some sort of emancipation plan at the state's third constitutional convention in the fall. Proslavery legislators realized that to repeal the Nonimportation Law of 1833 just months prior to the constitutional convention would send a resounding message to both proslavery and antislavery advocates throughout the state. The message of course would have very different meanings depending on which side of the issue one happened to be on. For proslavery proponents they viewed the

1849, American Colonization Society Records 113 (3): 32969-70, Library of Congress, Washington, D.C.; Niles Register, June 13, 1849.

${ }^{6}$ For a record of votes and debate on the repeal of the Nonimportation Law of 1833 , see Kentucky, General Assembly, Senate Journal (1848-49), 274-78, 284-85, 316-17, 363; Kentucky, General Assembly, House Journal (1848-49), 263-69, 272-74, 282-84, 449-50; See also, Martin, "Anti-Slavery in Kentucky," 95-97; Harrison, Antislavery Movement, 55-56; Frank F. Mathias, "Slavery, the Solvent of Kentucky Politics," Register of the Kentucky Historical Society 70 (January 1972), 14. 
repeal as a huge victory and proof that slavery should not be interfered with at the constitutional convention. For antislavery advocates it was thought, the repeal would suggest the proslavery sentiment among a majority of people within the state and antislavery men would defer to that majority voice. From a legal perspective the repeal of the Law of 1833 circumvented the antislavery forces ability to cite the law as a precedent for the state's acknowledgement that it was necessary to place limits on the institution of slavery within Kentucky by restricting the number of slaves in the state for the future. Thus, the repeal gave emancipationists grounds on which to strengthen their antislavery position and preserved the principles of the Nonimportation Law of 1833 in the new state constitution. From both a political and legal perspective the proslavery legislator's ability to secure repeal of the Law of 1833 was for them a major victory and is evidence that a majority of those living within the state did not want slavery interfered with at the state constitutional convention.

Antislavery advocates within the state also formed an organization in an effort to adopt a platform for the state's constitutional convention. Emancipationists from across the state convened a meeting at the state capitol in Frankfort during April 1849. The emancipationist coalition formed a special committee, the Corresponding and Executive Committee on Emancipation, to promote their antislavery cause throughout the state.

The committee raised awareness by publishing antislavery pamphlets distributed throughout the state. They held public forums were held throughout the state that featured antislavery speakers to promote the emancipationist's antislavery agenda. The committee also raised money to promote their antislavery message in the state. ${ }^{7}$

\footnotetext{
${ }^{7}$ Louisville, Examiner, February 3, 17, 24, March 3, 17, 24, 31, April 7, 14, 21, 28, 1849; Martin, "AntiSlavery in Kentucky," 124-26, 129-30; Tallant, "Slavery Controversy in Kentucky," 261.
} 
The antislavery organization, however, was rife with internal divisions. While a handful of abolitionists such as John G. Fee opposed slavery on moral grounds, the vast majority of antislavery men favored gradual emancipation. The emancipationist's rooted their antislavery views in economic considerations and their approach to ending slavery varied greatly. While abolitionists and emancipationists could not agree on the reasons they opposed slavery or the approach to ending the peculiar institution within the state; an even larger problem was posed by the fact that emancipationists themselves could not agree on the method or approach to ending slavery in Kentucky. Along with other prominent emancipationists, Cassius Marcellus Clay disagreed with Henry Clay's post nati plan that called for gradual emancipation and colonization. Cassius Clay argued that many people throughout the state felt that colonization was not practical and any proposed antislavery measure that included colonization would not be passed. Most antislavery proponents however, likely would have accepted Henry Clay's emancipation proposal. Antislavery supporters also disagreed on whether emancipation should begin immediately or at some distant time in the future. Other antislavery advocates argued that any emancipation proposal would be defeated by the voters in the Commonwealth thus, according to them no emancipation plan should be put forward. Instead they argued slavery reform should be pursued at some distant time in the future when the voters in the state might be willing to accept emancipation. ${ }^{8}$

In April 1849, in Frankfort, the schism between the contending antislavery views became apparent at the antislavery convention. At the convention two primary groups

\footnotetext{
${ }^{8}$ Louisville, Examiner February 17, 24, March 24, 31, April 7, 14, 21, 28, 1849; Victor B. Howard, "Robert J. Breckinridge and the Slavery Controversy in Kentucky in 1849," Filson Club History Quarterly 53 (October 1979), 334-35.
} 
emerged and advanced their approach to achieve slave eradication. One coalition advanced a proposal that called for the implementation of a guaranteed plan of emancipation in the new state constitution. More conservative antislavery advocates were careful not to propose any emancipation plan that may be viewed as radical by the majority of Kentucky voters. Therefore, the conservative antislavery forces proposed a plan that called for establishing in the new state constitution the principle of nonimportation as well as providing a provision allowing for voters to decide emancipation at a future date independent of calling a constitutional convention. By the end of the convention antislavery reformers had devised a report that denounced slavery as an evil but stopped short of calling for any immediate plan for emancipation in the state. The final report also called for including the non-importation principle into the new state constitution. The report also supported the so called open clause that would allow for new amendments to the constitution without calling a convention to consider the whole document or allow for a referendum on the matter of emancipation at some future date. In the end, it was clear the antislavery conservatives dominated the convention and devised an antislavery strategy that called for a moderate approach to ending slavery at some future point in time when perhaps, the majority of Kentucky voters would be willing to accept emancipation. Although the majority of Kentucky voters were proslavery at this time, even the antislavery voters in the state remained conservative on the issue of emancipation. The vast majority of the state's antislavery advocates were not in favor of immediate emancipation or even immediate gradual emancipation. Therefore, the antislavery conservative agenda reflected a majority view among the state's antislavery supporters. ${ }^{9}$

\footnotetext{
${ }^{9}$ Clement Eaton, ed., "Minutes and Resolutions of an Emancipation Meeting in Kentucky in 1849,"
} 
After both sides of the slavery issue held their own conventions to formulate an agenda for the state constitutional convention in the fall of 1849 , the stage was set for delegates from both sides to meet at the convention to address the issue of devising a new state constitution. Although initially, both the proslavery proponents and antislavery advocates downplayed the role slavery would have on forging a new state constitution it was clear from the outset that slavery's significance could not be denied and was at the forefront of both the antislavery advocates and the proslavery forces respective agendas. They dedicated over half of the convention's platform to the slavery question. Prior to and during Kentucky's Third State Constitutional Convention political party affiliation, took a backseat to a delegate's view toward slavery. The divisive slave issue proved to penetrate party lines in some cases as the fusion tickets for the election of convention delegates shows. Many in Kentucky were willing to forego their political party affiliation, whether Whig or Democrat, but were unwilling to relinquish their view towards slavery. This strong attachment to the peculiar institution among the voters of Kentucky suggests the profound impact slavery had in the Commonwealth. Both supporters and opponents of emancipation in Kentucky diminished the prominence the slave issue would play at the state constitutional convention. However, no doubt existed that once the convention began the primary goal of members on both sides of the slavery issue was to deal in a meaningful way with the question of slave emancipation, in an effort to put the divisive issue to rest.

Although the antislavery movement had grown in Kentucky and by 1849 represented a significant minority of voters across the state the fact remained that a majority of voters "Breckinridge and the Year 1849," 133-34; James P. Gregory, "The Question of Slavery in the Kentucky Constitution of 1849," Filson Club History Quarterly 23 (April 1949), 92. 
statewide elected a proslavery majority to serve as delegates to the state's third constitutional convention. The proslavery forces were aware of the antislavery movement in the state and although there were many more proslavery proponents statewide the potential threat from a growing antislavery sentiment within the state could not be denied. Therefore, the perceived threat from the antislavery movement served as an impetus for the state's proslavery forces to strengthen slavery in the new constitution.

At the convention, proslavery men pointed to several concerns as to why slaves could not be emancipated in the Commonwealth. Among the concerns for most Kentuckians was the fear of living among freed slaves. Many proslavery supporters realized that African colonization was not practical and pointed to prominent antislavery men such as Cassius Marcellus Clay who also argued the impracticality of colonization for freed slaves. Delegates raised concerns over compensation to slave owners who would be forced to emancipate their slaves. Many proslavery proponents argued emancipation in Kentucky was impossible to achieve and argued for its perpetual continuation. Radical proslavery men called for placing limits on the political rights of many whites within the state to stifle those who argued free white labor and small farmers suffered economically as a result of slavery in Kentucky. Others advocated abolishing the state legislature's right to pass any form of a compensated emancipation plan. ${ }^{10}$ Many proslavery delegates, however, realized the mood of the electorate within the Commonwealth and accordingly advocated pursuing a moderate course regarding slavery in the state. These proslavery advocates argued that the old state constitution provided for preserving the institution of slavery in Kentucky and the voters had in fact elected them to the

${ }^{10}$ See Kentucky, Report of the Debates, 71, 83, 94-101, 115, 488, 514-15, 918, 924-25, 928-29; See also, C. Fields, "Kentucky's Third Constitution," 168-69, 188-89; Gregory, "Question of Slavery," 93-94. 
convention to ensure the slave provisions in the old constitution would not be interfered with in the new state constitution.

While the old constitution was adequate to continue slavery in the state it did not guarantee that slavery would continue in perpetuity. This meant that while the voters of Kentucky did not want slavery abolished immediately or even gradually in the state; they likewise did not seek to guarantee perpetual slavery. For many this stance suggested that Kentuckians were ambivalent regarding the future of slavery in the Commonwealth. This position also suggests that other factors may have been pressing on the minds of many Kentucky voters, such as the adverse impact that slave labor may pose for free white labor in the future. It also suggests that voters in the state may decide they no longer desire the presence of large populations of African slaves living among them and, thus, could have a means to emancipate slaves in the future. In any case, proslavery delegates at the convention had to move carefully so as not to risk alienating the state's proslavery voters, who could give their support to emancipationist candidates in future elections. The moderate proslavery delegates were the majority among proslavery supporters at the convention and they were careful to pursue a course of careful moderation concerning slavery provisions as they existed under the old constitution. In the end they recognized non-interference regarding slave emancipation in the old constitution was the best course of action they could pursue and reflected the majority proslavery sentiment throughout the state.

Upon examining the actions of the convention's delegates it becomes clear that while proslavery men understood the importance of not alienating voters who supported noninterference with emancipation under the old constitution; they likewise believed it 
necessary to strengthen the institution of slavery under the new constitution. The convention's committee on slavery delivered a report to the full convention that called for retaining most of the language from the slave clause contained in the Constitution of 1799, which derived from the state's original Constitution of 1792. The committee on slavery proposed that the convention adopt measures that again prohibited the state legislature from emancipating slaves in the Commonwealth without obtaining the slave owner's permission or without compensating the owners for the full value of their slaves. In addition, the legislature would be required to pass legislation that would allow for slave owners to free their slaves. Also, the legislature could pass laws that would limit slave importation into the state for the purpose of resale. The legislature could not, however, pass laws restricting slave owning immigrants from bringing their slave property with them when moving into the state. ${ }^{11}$

The committee also recommended provisions designed to limit growth of free blacks in the state as well as to place restrictions on emancipation. For example, the legislature could not adopt any post nati emancipation scheme without compensating the owners. The legislature also could not authorize slave owners to free their slaves without also providing for the removal of those freed slaves from the Commonwealth. The committee on slavery also recommended measures that allowed the state legislature to remove free blacks from the state and also require the state to imprison any free black immigrants into the state after the new constitution was adopted. ${ }^{12}$

The majority of the convention delegates proslavery stance became more apparent in the closing weeks of the convention as Garrett Davis proposed an amendment to the state

\footnotetext{
${ }^{11}$ Kentucky, Report of the Debates, 69-70.

${ }^{12}$ Ibid.
} 
bill of rights that stated, "the right of property is before and higher than any constitutional sanction; and the right of the owner of a slave to such a slave, and its increase, is the same, and as inviolable as the right of the owner, of any property whatever."13 The language contained in the Davis amendment guaranteed that no future post nati emancipation plan could be enacted without compensation to the slave owners.

The Davis amendment suggests the strong proslavery sentiment among a majority of the convention's delegates. For the majority of Kentucky's proslavery proponents the slave question was a matter of property rights. The Davis amendment allowed for the individual slave owners within the state to retain control of their property and guaranteed to them compensation for their property regardless of the majority will in the Commonwealth in the future regarding the emancipation of slaves.

The addition of the Davis amendment to the new constitution's bill of rights was a strong proslavery measure at a time when proslavery rhetoric had called for moderation on the question of slavery in the new constitution. After the adoption of the Davis amendment the proslavery supporters seemed appeased and thus were more willing to compromise on other slave issues. Many proslavery convention members had advocated limiting the growth of free blacks within the state as well as, a provision to prohibit the state legislature's right to pass a future plan of compensated emancipation. After achieving a victory in the form of Garrett Davis' amendment, however, these strong slavery supporters settled for a revision of the second constitution's slave clause. The new slave clause included much of the old clause, but required the state legislature to pay for the removal of any slaves freed through any form of a compensated emancipation

\footnotetext{
${ }^{13}$ Kentucky, Third Constitution (1850), article 13, section 3; See also, Kentucky, Report of the Debates, $815,856-61$.
} 
plan. ${ }^{14}$ This clause served two purposes: on the one hand, it worked to effectively limit the growth of a free black population within the state and, second it would also make any scheme of compensated emancipation so expensive the plan would render emancipation impractical.

Other actions taken by the convention on emancipation proved moderate as well. ${ }^{15}$ Chief among them was the question of slave importation into the state. This issue proved divisive as many in the state, primarily Democrats, advocated a constitutional guarantee for the people's right to import slaves into the state for their own purposes. The Democrats feared the legislature may pass legislation to restrict slave imports into the Commonwealth just is it had in the spring session, when it voted to repeal the Nonimportation Law of 1833. The proslavery men also pointed to the adverse effects the limits on slave imports would pose to small farmers in Kentucky who could not rise to economic and social prominence without the ability to acquire slaves. Many other delegates to the convention, primarily Whigs, advocated leaving the question of slave imports to the legislature. They feared to include slave importation in the new state constitution, thus removing the issue from the purview of the state legislature would risk alienating many voters across the state, forcing them to shift their support to the emancipationist cause. In the end, most Whigs pointed to the recent vote by the legislature to repeal the Nonimportation Law of 1833 as an indicator that slave importation would continue in the state. Thus slavery and the ability of the people of the Commonwealth to continue to import slaves would likely continue so long as the issue remained under the control of the legislature.

\footnotetext{
${ }^{14}$ See Kentucky, Report of the Debates, 914-921.

15 Ibid., 76-77, 936-37.
} 
When the state's third constitutional convention came to a close the institution of slavery proved more entrenched under the new constitution than it had ever been. The new constitution made it more difficult for any emancipation scheme to be implemented in the Commonwealth. According to a report published by convention delegates that explained their actions regarding slavery in Kentucky they concluded that slavery was not viewed by the convention as evil. In their view slavery was a positive good that according to the report was "a great element of wealth, and social and political power [that] will remain undisturbed and secure, so long as this constitution shall continue the paramount law of the land." ${ }^{16}$ This explanation stood in contrast to a majority of the Kentuckian's view that slavery was in fact a necessary evil. The convention delegates viewed slavery in practical terms, from a purely legal, political and economic perspective that lent itself to their assimilating slavery with a positive good interpretation. When considered in the context of the convention it is understandable how the delegates could posit this positive good view. Although the people of Kentucky understood slavery's practical significance for their state; personal feelings derived from a moral perspective often lent itself to formulating their views toward slavery thus leading many to adopt the necessary evil theory when postulating their proslavery stance.

Kentucky's Third State Constitution bolstered slavery in the state. The new constitution guaranteed the continued existence of slavery in Kentucky into the future and perhaps, for all time. Slavery was firmly entrenched in the Commonwealth and the proposed constitution spurred many Kentuckians to support slavery more than ever before. Kentuckians did not abandon their sentiments that slavery was morally wrong;

\footnotetext{
${ }^{16}$ Ibid., 1088; See also William M. Wiecek, The Sources of Antislavery Constitutionalism in America, 1760-1848 (Ithaca: Cornell University Press, 1977), 279.
} 
but, they continued to cite the practical necessity for the peculiar institution in their state. Kentuckians believed slavery was necessary to control the black race and that it was impossible for the two races to peacefully coexist as equals. Also, Kentuckians understood the economic rewards reaped by many in the state due to slavery. Kentuckians also realized the social significance slavery held in their state as nonslaveholders could aspire to acquire slaves thus, elevating their social and economic status. It was rather easy for Kentuckians to continue their proslavery stance considering the cultural heritage of many in the state who had come from southern roots. Of course, the long standing legal justification to own property in persons and the constitutional right to have one's property rights protected made it easy for Kentuckians to continue to support slavery. The Constitutional Convention of 1849-50 strengthened the peculiar institution in the Commonwealth. During the coming decade Kentuckian's proslavery stance grew stronger in response to national events.

Beginning in 1850 the Whigs in Kentucky shifted their focus from slavery and advanced a strong pro-Union stance in support of the so called Great Compromise of 1850. Kentucky's own United States Senator John J. Crittenden advanced his compromise proposal in an effort to avert sectional conflict and perhaps, disunion. Until 1852, the Whigs in Kentucky held a strong pro-Union position for two years. During 1853 the Whig Party refocused its efforts once again on a proslavery strategy for the Commonwealth. The Whig Party in Kentucky had proven effective in sensing the mood of the electorate within the state and had adjusted its political agenda to fit the majority of Kentucky voter's demands thus, continuing its political legitimacy and success within the Commonwealth until 1855. 
In the aftermath of the Kansas-Nebraska Act of 1854 , the Whig Party was weakened nationally and Kentucky was no exception. Critics accused the Kentucky Whigs of vacillating between issues in an effort to enhance their political appeal among the electorate. Over time, the Whigs changing focus between the issues of pro-Union and proslavery caused many voters to believe the critic's accusations that the Whigs in Kentucky were more than willing to sacrifice principle for votes. Also, the rise of the Know-Nothing Party emerged in the state as an increase in nativism and anti-Catholicism gained prominence within the Commonwealth. The political leaders in the Whig Party decided the popularity of the Know-Nothing movement provided too much of a challenge for the Whigs in 1855 and accordingly made the decision to forgo the 1855 elections. The Whigs constituents followed suit and left the Whig Party. The detractors threw their support to the new Know-Nothing Party subscribing to its nativist and anti-Catholic position. $^{17}$

The Whigs in Kentucky had endured much criticism from their Democrat opponents for shifting their political strategy between slavery and Unionism. The Whigs, however, did not view the two issues as being mutually exclusive and saw no contradiction in their political strategy. The Kentucky Whigs argued the best way to maintain slavery was to preserve the Union. Thus, the Whigs did not view reemphasizing their focus between the two issues as forsaking their principles for political gain.

Despite the Whig Party collapse in Kentucky in 1855 many former Whigs continued to adhere to the Whig ideology that promoted preservation of slavery and Union. The

\footnotetext{
${ }^{17}$ See, Michael F. Holt, "The Mysterious Disappearance of the American Whig Party," in Political Parties and American Political Development from the Age of Jackson to the Age of Lincoln (Baton Rouge: Louisiana State University Press, 1992), 239-41, 246-51; Volz, "Party, State, and Nation," 171-73.
} 
majority of Kentuckians clung to their notion of a Commonwealth that belonged to the Union but also maintained its system of slavery.

During the presidential election of 1860 Kentuckians faced the choice of electing a Republican presidential candidate, Kentucky's native son Abraham Lincoln, and certain disunion or elect one of several proslavery or pro-southern rights candidates, and in so doing, preserve the Union. While the majority of Kentuckians were proslavery men most Kentuckians believed slavery was best protected under the federal constitution. Therefore, although the hot button issue for the 1860 presidential contest for the South was the protection of slavery, in the Upper South border slave state Kentucky, the key issue was about preservation of the Union.

The Opposition Party that emerged in 1860 , in Kentucky blended the old line Whig ideology that promoted a proslavery and pro-Union agenda. The Oppositionists in Kentucky equated their proslavery stance with Unionism, not southern rights. Therefore, the moderate approach taken by Opposition men in Kentucky sought to navigate a political course between two extremes: the fire-eaters of the southern states, who advocated protecting southern rights at all costs, including of course adopting secession, and the abolitionists in the northeast who sought to abolish slavery, even at the cost of disunion. Upon examining the actions of the Opposition Party in Kentucky leading up to the presidential election of 1860 , while slavery was an important part of the Oppositionist's political agenda, it placed second behind preservation of the Union.

In 1860, the Opposition Party held a state convention in Frankfort in an effort to build a coalition to strengthen the Party's chances in the impending election. ${ }^{18}$ United States

\footnotetext{
${ }^{18}$ See, Kentucky, House Journal, 1859-60, 171-73, 275-285, 313-315; Louisville, Journal, 11 January 1860.
} 
Senator John J. Crittenden worked in the nation's capitol to build a national coalition of support among former Whigs and Know-Nothings as well as moderate Republicans. In Frankfort, the Opposition Party worked to organize a national Union Party that promoted Unionism first and abandoned the sectional politics of both the Republicans and the Democrats. The Oppositionists did not believe it was necessary for Congress to protect slavery through legislation. They believed the United States Constitution guaranteed the right to own property in persons. Also, the enforcement of the fugitive slave law was sufficient to protect southern property rights. Therefore, the Oppositionists viewed maintaining the Union as it was, as sufficient to preserving southern rights.

The Opposition men further sought to differentiate themselves from proslavery democrats and espoused their platform, that the "people of Kentucky are for the Union and the Constitution." The Oppositionists in Kentucky emphasized the importance of maintaining the Union as a counterweight to their political opponent's views that slavery or the eradication of it was their primary focus despite the risk of disunion. The Oppositionists in Kentucky recognized the only way to maintain the Union was to adhere to the federal Constitution, the United States Supreme Court's interpretation of the Constitution and the enforcement of the fugitive slave law. This view was rooted in the old line Whig ideology that advocated an adherence to the existing laws. This notion took hold nationally as well, particularly in the Upper South and the border south slave states, as the new Constitution Union Party was formed. John Bell of Tennessee and Edward Everett both former Whigs, lead the ticket and adopted the party platform "the 
Constitution, the Union, and the enforcement of the laws."19 Thus, in Kentucky, the Oppositionist men found in the new Constitutional Union Party a platform consistent with that of their own and in harmony with the old-line Whig ideology that still prevailed among a majority of the voters in the commonwealth, five years after the Whig Party had collapsed in the state.

In the presidential contest of 1860 Kentucky voters voted for John Bell and the Constitution Union Party with just over 45 percent $(66,068)$ of the total votes cast. The Democrat Party, of course, split in the state. Kentuckian and United States Senator and proslavery, pro-southern rights man, John C. Breckinridge received 36.3 percent $(53,146)$ of the vote. The largely pro-Union Democrat Stephen A. Douglas garnered 17.5 percent $(25,641)$, a respectable showing, considering that Douglas defeated Breckinridge in four out of ten congressional districts in the state. ${ }^{20}$ A significant number went for the Democrats as a whole, as the two Democrat candidates received 53.8 percent of the total votes cast. To conclude the strongest Democrat candidate, Breckinridge would have defeated John Bell if Douglas had not run is erroneous. It is likely that many of Douglas's supporters would have crossed over and voted for Bell in the name of preserving the Union as the best means to protect southern rights. The Republican candidate, Kentucky's native son, Abraham Lincoln, received less than one percent of the statewide total with 1,365 votes. In the minds of Kentuckians Lincoln's election, would have certainly caused disunion. Therefore, based on the election results, one can reasonably conclude that in Kentucky the chief goal was preservation of the Union.

\footnotetext{
${ }^{19}$ See, Louisville, Journal, 24 February 1860, 2-3; 29 February 1860, 2; 11 May 1860, 2; See also, Letcher to Crittenden, 1March 1860, Crittenden Papers, film M-757; Letcher to Crittenden, 2 April 1860; Crittenden to Frankfort Yeoman, May 1860, Crittenden Papers, film M-302.

${ }^{20}$ For complete election results see, Walter Dean Burnham, Presidential Ballots 1836-1892 (Baltimore: The John Hopkins Press, 1955), 238, 252-54.
} 
Following the presidential election of 1860 the states of the Deep South began to secede. During the secession winter, the border slave state of Kentucky grappled with the complex issues that surrounded secession and the challenge of making a decision to remain loyal to the Union or join their proslavery counterparts and secede. Ideology figures prominently in Kentuckians ultimate decision to remain loyal to the Union in the midst of the secession crises.

Unlike the other southern states Kentucky, chose to adopt a moderate approach to navigate the political turmoil of the secession crises. Kentuckians of all three major political parties at first sought to preserve the Union. Even the Breckinridge Democrats did not feel that Lincoln's election to the presidency was an adequate reason for dissolving the Union. These proslavery and southern rights men believed that the United States Senate remained strong enough to circumvent any attempt on the part of Lincoln to end slavery. Governor Beriah Magoffin wrote a letter to the Frankfort Yeoman and proclaimed that Lincoln's gaining the presidency was not a sufficient reason "for secession or rebellion." Magoffin further stated that Kentucky, "will not submit to the carrying out of his [Lincoln's] principles."21 Constitutional Unionists supported loyalty to the Union and accordingly they encouraged Kentuckians to support their Unionist cause. Despite subtle differences in the taken approach or spoken rhetoric, in the beginning of the secession crises, the varying political elements in Kentucky agreed that Lincoln's election was not a sufficient reason to merit dissolution of the Union.

As the secession crises deepened and it became apparent there was no easy alternative solution for convincing the Deep South states not to secede, Kentuckians' initial agreements faded and discord set in. The sudden belief among many proslavery, pro-

${ }^{21}$ Magoffin to S.I.M. Major [editor of the Frankfort Yeoman], 16 November 1860. 
southern rights Democrats in the Commonwealth that Republicans would take control of the Congress in the midterm elections in 1862 spurred their actions to begin to advocate for secession. The fear of abolitionism set in as well and many felt Kentucky would follow abolition trends in other parts of the country. ${ }^{22}$ Many in Kentucky including Senator John J. Crittenden, followed the old line Whig strategy long favored by Henry Clay and advocated a compromise solution in an effort to appease proslavery, prosouthern rights men and also, pro-Union supporters. ${ }^{23}$ This task proved challenging as many compromise advocates desired to remain in the Union despite the threat the North's actions posed for slaver. Others advocated a proslavery state convention that would craft its own solution to the problem and present it to the North for their support. Governor Beriah Magoffin supported this idea and his support suggests his proslavery, pro-southern rights stance despite his professed allegiance to the Union. Magoffin offered a compromise solution to the fourteen slave states, although many anti-secession proponents rejected his plan. ${ }^{24}$ His efforts at compromise, however, were weighted toward appeasing the South at the risk of alienating the North. Therefore, Magoffin's early compromise efforts were a good indication of his later pro-Confederate stance. In the midst of the secession crisis Kentucky found itself divided about how best to approach the dilemma it faced, of whether to abandon the Union and join the pro- slave Confederacy or to cling to the notion that the Commonwealth could remain loyal to the Union and maintain slavery within the state.

In December 1860, after South Carolina seceded, the crisis became real and efforts to react to it within the Commonwealth took on an unprecedented urgency and gravity. The

\footnotetext{
${ }_{22}^{22}$ See, Louisville, Courier December 14, 1860, 1; December 15, 2; December 18, 2; December 20, 2.

${ }^{23}$ Crittenden Papers, Garrett Davis to Crittenden December 10, 1860, film M-302.

${ }^{24}$ Beriah Magoffin to Southern Governors, December 9, 1860, in House Journal, January 1861, 19.
} 
reaction by the Governor and legislature needed to be quick and decisive. The pace of events had accelerated to a point that made many in the legislature and the governor uncomfortable in announcing any official position for the state regarding its plan to secede or maintain its loyalty to the Union. Kentucky's political actors could not agree on a definite course of action for the Commonwealth. As a result, they did what any divided state would do and what for Kentuckians came naturally; they crafted a compromise solution designed to meet the demands of both proslavery, pro-southern rights men and proslavery, pro-Union men within the state. The state House of Representatives took on the challenge of devising a policy to meet the state's objectives to appease both sections and also to keep Kentucky out of the war. The result was a policy of neutrality that passed $69-26$, in the House. The resolution of neutrality stated:

Considering the deplorable condition of the country and for which the State of Kentucky is in no way responsible, and looking to the best means of preserving the internal peace and securing the lives, liberty, and property of the citizens of the State; therefore,

Resolved by the House of Representatives, that this State and the citizens thereof should take no part in the civil war now being waged, except as mediators and friends to the belligerent parties; and that Kentucky should, during the contest, occupy the position of strict neutrality.

Resolved, that the act of the governor in refusing to furnish troops or military force upon the call of the executive authority of the United States under existing circumstances is approved. ${ }^{25}$

On May 20 Governor Magoffin endorsed the legislature's policy publicly. While many argue this proved Magoffin's willingness to attempt at least to remain loyal to the Union, it actually suggests further his pro-southern, pro-Confederate sympathies, as Kentucky's neutrality policy implied the Commonwealth had a right to declare

${ }^{25}$ Kentucky, House Journal, May 1861, 91-8. 
independence from either section, citing state sovereignty. Thus, the people of the commonwealth, according to this reasoning, could assert their independence further if necessary to likewise, secede from the Union. It is plausible to suggest that Magoffin hoped the people of Kentucky would adopt this approach upon realizing they held the power through their sovereignty to resist any coercion from the North. Neutrality was a victory for pro-Union men in the state as it allowed Kentucky to avoid secession and for a time also the war. In any case neutrality worked to serve the purposes of pro-southern rights and also pro-Union men in the short run. However, in the long term, the state's belief that it could walk a tight rope between the contending sections proved erroneous. In the end, neutrality in Kentucky prolonged what many feared: Kentucky's hand would be forced and the people of the Commonwealth would have to choose between joining the proslavery Confederacy or remain loyal to the Union.

The first indications of a majority of Kentuckian's views were displayed in the results for the Congressional election held on June 20 in the state. The elections had been scheduled for August but, Lincoln called a special session of the Congress to convene on July 4 to confront the secession crisis. The pro-southern rights political strategists argued that Union men endorsed Lincoln's plan to abolish slavery and impugn the Southern state's rights. While on the other end of the political spectrum, pro-Union men argued that the election issue was treason or loyalty to the Union. Of course, both sides kept busy refuting the other's claims and continuing their attacks on one another. The Union men employed an effective political strategy that argued southern rights men would vote for secession if given the chance. The Union men emphasized that secession meant the war would penetrate Kentucky's borders making it into a fierce battleground caught 
between the crossfire of the warring sections. According to the Unionists, this fate would spell the end of slavery in Kentucky. The Unionist's also understood their limitations and conceded the First Congressional District in the far western section of the state was a pro-southern rights stronghold. Nevertheless, the Unionists remained confident they could win the remaining districts, particularly with Kentucky's newest political star, United States Senator John J. Crittenden, running for the state's Eighth Congressional District seat. ${ }^{26}$ John J. Crittenden had become the state's new champion of compromise following the death of Henry Clay. Crittenden invoked Henry Clay's Whig strategy that made every effort at compromise in an effort to maintain the Union. The Unionist Party in Kentucky realized that no one within the Party would challenge the Senator and that his ideology and compromise record was more consistent in their view with the majority of the voters in the Eighth District than their pro-southern rights opponents. The Unionists in Kentucky bet on the reluctance of a majority of the voters in the state to forgo the Union for the sake of preserving their pro-southern rights cause. The Unionists observed that the majority of the people in the Commonwealth wanted to avoid all possibility of war in their state. Although in time, this hope was not possible, a majority of Kentuckians would rather cast their lot with the Union as the best means to protect their rights, including their slave property, rather than commit treason and join the Confederacy. In the end the Unionist's strategy proved effective and the Commonwealth of Kentucky sent nine of ten representatives to the nation's capitol in July.

\footnotetext{
${ }^{26}$ For complete election totals see, Guide to U.S. Elections, 1007.
} 
To counter E. Merton Coulter's claim that the election was in fact a referendum on neutrality not Unionism, ${ }^{27}$ one can analyze the election results of 1859 and compare the two contests in an effort to understand the implications of the 1861 congressional election in the state. Coulter himself compares the 1861 congressional election to the 1860 presidential election, stating, "The total vote in the [1861] election was less than half the number cast in the presidential election of the preceding year." The presidential race, however, had captured the nation's attention in a way unlike any other. Many in the South including Kentucky believed the Union's future hinged on whether Abraham Lincoln was elected to the presidency. This uncertainty contributed to a growing sense of urgency among the electorate. This feeling of uncertainty and urgency lent itself to a strong desire among the electorate to make their position known. Also, the Democrat Party in Kentucky was split and the choices were two popular candidates, Kentucky's native son, and pro-southern rights Senator John C. Breckinridge and pro-Union Democrat, Senator Stephen A. Douglas.

Thus, to compare the Congressional Elections of 1859 and 1861 provides a more accurate picture of the state's turnout for Congressional races generally. In so doing, one can ascertain the true intent of the people of Kentucky in the 1861 election. Upon close examination it becomes clear the election results can be relied upon to determine the state's majority position on the question of Union. The election results show that overall voter turnout was down slightly in 1861 than in 1859 , with a total of 122,032 to 141,212 respectively. In the Sixth District the incumbent ran unopposed on the ballot and voter turnout was down from 15,395 in 1859 to 8,326 in 1861 , a difference of 7,059 votes

\footnotetext{
${ }^{27}$ See, E. Merton Coulter, The Civil War and Readjustment in Kentucky (Chapel Hill: The University of North Carolina Press, 1926), 95.
} 
accounting for more than one third of the voter decline in all ten Congressional Districts in the 1861 election. In the First District in far western Kentucky, a hot bed for prosouthern rights and pro-secession advocates there was an increase in voters in 1861. In addition, the Third, Seventh and the hotly contested Eighth District in the Bluegrass Region, the largest pocket of slaveholders in the state, all saw increases in voter turnout. The First and Eighth Districts merit closer examination. In the First District the prosouthern rights Congressman Henry Burnett won reelection, in his four bids for the seat the pro-Union challenger proved his most formidable opponent. Also, voter turnout increased in the First District by nearly 1,500 votes from the 1859 election. The ever important Eighth District in the Bluegrass Region of the state was hotly contested, as the pro-Union challenger and prominent United States Senator John J. Crittenden defeated the pro-southern rights incumbent Congressman William Simms by 2,566 votes. In the Eighth District voter turnout increased slightly in 1861 as well.

Therefore, upon comparing the Congressional Elections of 1859 and 1861 one can conclude that the number of those who cast a ballot in the 1861 election had declined slightly from the 1859 election; however, voter turnout increased in the most contested districts, the First and the Eighth, both of which were the two largest slaveholding sections in the state. In the Eighth the pro-Union candidate won, while in the First the long time incumbent received his greatest challenge in four bids for the seat. While it is true, as Coulter suggests, that the number of voters in the 1861 Congressional Election "was less than half the number cast in the presidential election of the preceding year," is erroneous to compare the two elections as Coulter has done to undermine the proUnion gains made during the contest.

28 Ibid. 
Clearly, the two elections do not compare favorably. Historically of course presidential contests typically yield higher voter turnouts than do congressional races. Also, one must consider the fact that in the 1861 congressional election voter turnout increased in four of the ten congressional districts relative to the 1859 congressional election. Also, one seat was unopposed and accounted for over one third of the voter decline among all the districts. These numbers mean that in sum only five of the ten congressional districts witnessed a decline in voter turnout in the 1861 congressional election relative to the 1859 congressional election. Therefore, the decline in voter turnout was not nearly as great as Coulter erroneously claims by comparing it with the presidential election of 1860. It is likewise erroneous to conclude as Coulter has done that the decline in the number of ballots cast reflected the fact "that the Southern Rights Party had spurned the election and had stayed away from the polls generally." ${ }^{29}$ In both the First and Eighth District races the Pro Southern Rights Party did not spurn the election but rather turned out in force to attempt to retain these seats in the state's two most pro-Southern rights, pro-secession districts. To further diminish the pro-Union gains made in the congressional election Coulter, asserts that, "many Southern Rights men felt it highly illogical and futile to take any further part in the degraded politics of the state. ${ }^{30}$ However, to interpret the election results as Coulter has done, by suggesting that the pro-Southern Rights men conceded the election to the Unionists due to their disgust with the state of political affairs within the Commonwealth through nonparticipation, does not reflect the Unionist sentiment in the state. This interpretation fails to determine what the results of the contest might have been if the Southern Rights

\footnotetext{
${ }^{29}$ Coulter, Civil War, 95.

${ }^{30}$ Ibid.
} 
Party had turned out in all the districts across the state. No clear method exists to conclude as Coulter has done, that the Unionists would not have carried the majority of the state's ten congressional districts despite the votes cast by the Southern Rights Party. Therefore, Coulter's assertion to the contrary is mere speculation. What is known, however, is that in the congressional election of 1861 , the majority of the ballots cast reflected the state's pro-Union sentiment.

Coulter further argued that the election "was interpreted generally as being the overwhelming expression of the state for neutrality - the first popular referendum on this subject since the state had announced its position." 31 Once again Coulter's proConfederate interpretation of the election is flawed. Neutrality benefited both pro-Union and pro-Southern rights advocates in the Commonwealth. While it is true Unionists would have accepted and supported neutrality, it is likewise true that pro-southern rights, pro-secession men would have also supported neutrality. The election could have had different meanings for the two sides. The pro-southern rights supporters could have interpreted the impact of the election results as a referendum on neutrality, just as easily as the pro-Union advocates as they had much to gain by supporting the state's neutrality policy. This issue begs the question: why then did the pro-southern rights men forgo the election-as Coulter wrongly claims-- altogether? The Unionists could have interpreted the election's outcome as reflecting a majority pro-Union sentiment in the state. The fact the emphasis on the maintenance of the Union-not neutrality-- was the primary goal of the Unionists in Kentucky suggests that for them the congressional election was a referendum on Union in Kentucky, not neutrality. It is possible that the Unionists could also have treated the election as a referendum on neutrality as they benefited in the short

\footnotetext{
${ }^{31}$ Ibid.
} 
term from that policy as well. To refute Coulter's claim it becomes less important to understand how the Unionists interpreted the election results and more necessary to comprehend what the results meant to the pro-southern rights men. It becomes even more necessary to determine what the real reasons were for the southern rights supporters to stay away from the polls as Coulter claims. The Southern Rights Party only stayed away from the polls in those districts where they had the least chance of winning, outside of the largest slaveholding and pro-secession districts, where they remained confident in their ability to win. It seems unlikely that Coulter's assertion that Kentucky's 1861 congressional election was a referendum on neutrality is accurate when the actions of both parties and the election results show it was a referendum on Unionism.

As the secession crisis continued and events at Fort Sumter occurred, Kentucky's neutrality policy was not practical. Kentuckians faced the increasing challenge to maintain a policy of neutrality. Kentuckian's desire to avoid war in their state served as the chief impetus to craft a solution to the complex problems of secession and the war that followed. Kentucky also had much at stake economically and thus, held to the notion that the Commonwealth could maintain trade with both sections. As events unfolded and the war continued it became evident that Kentuckians would be forced to respond to events, abandon the neutrality policy and choose with which section it would cast its lot. In September 1861, Confederate General Leonidas Polk invaded Kentucky and a majority of Kentuckians made the decision to take up arms and defend the Union. Kentuckians decided to maintain their loyalty to the Union. They believed that their right to own property in persons was best protected under the United States Constitution. Therefore, maintaining the Union served as the best means for protecting their rights. 
Kentuckians' decision to maintain its loyalty to the Union is not surprising, considering the fact that Whig ideology still prevailed in the Commonwealth five years after the party's death in the state. The best evidence that Whig ideology influenced a majority of Kentuckians' 1861 decisions is that Kentucky chose to remain loyal to the Union. This course was consistent with the view espoused by the Whig Party for decades leading up to the Civil War that southern rights and a nationalist interest could both be facilitated and protected only inside of the Union. In the end, Kentucky chose that course to navigate in the crisis of 1861 .

In September 1861, military events forced Kentuckians' to take a position and defend it. The course of neutrality had proved impractical. On September 4, 1861 Confederate troops entered the state and occupied the Mississippi River towns, Hickman and Columbus. According to Unionists this action violated the state's neutrality policy and required immediate action. Governor Beriah Magoffin and the southern rights men had already called for the removal of Camp Dick Robinson, a Union Army training camp from the state. However, the Unionist majority in the state legislature refused to act. The pro-southern rights men in the legislature proposed counter measures to the Unionist's demands that Confederate troops leave the state calling for the removal of Camp Dick Robinson from the Commonwealth. However, the pro-Union legislature refused to endorse any counter measures to their demands. In addition to violating the state's neutrality policy the refusal of Confederate troops to withdraw from the state justified the Unionists' defense of Union General Ulysses S. Grant's decision to enter Kentucky to defend Paducah. On September 11, 1861 the House Committee on Federal Relations submitted a resolution calling for Governor Magoffin to publicly announce "Kentucky 
expects the Confederate or Tennessee troops to be withdrawn from her soil, unconditionally." The resolution passed the House 71-26 and the Senate 25-8. While both chambers supported the removal of Confederate troops from the state neither called for the removal of Union forces. Governor Magoffin vetoed the pro-Union measures and the Senate promptly overrode his veto $25-9 .{ }^{32}$ The legislature was choosing to remain loyal to the Union.

Confederate President Jefferson Davis chose to keep the Confederate troops in Kentucky despite the resolution calling for their removal. Confederate Generals Leonidas Polk and Albert Sydney Johnston agreed with Davis. Davis, Polk and Johnston miscalculated Kentuckians response to their presence and the presence of the Federal troops within their state. The Confederacy remained confident that Kentuckians would turn to them for support as they sought liberation from the Federal troops. Perhaps this miscalculation prompted more Kentuckians to turn toward the Union. The Confederacy had violated Kentucky's neutrality policy and by refusing to withdraw from the state reinforced Kentuckians' suspicions of Confederate coercion within their state. In refusing to leave the state, the Confederacy provided little ammunition for the prosouthern rights men in Kentucky to use against the Unionists in an effort to dissuade their pro-Union stance. These bold actions on the part of the Confederacy to remain in Kentucky made neutrality in the state impossible. In essence, the refusal of the Confederacy to recognize and respect the Commonwealth of Kentucky's policies forced the Commonwealth's hand and made the decision for the majority of the people of Kentucky to resist Confederate coercion and cast their lot with the Union.

${ }^{32}$ House Journal, 1861-63, 81-5; Senate Journal, 1861-63, 80-6. 
On September 18, 1861 the Federal Relations committee in both the House and Senate passed resolutions that called for expelling the Confederate troops from the state and offered support for the Federal forces in the Commonwealth, recognizing their intent to protect and defend the state. The legislature passed two resolutions that requested Governor Magoffin's support, called for volunteers and the state militia to take action to defend the Commonwealth, and appointed Senator John J. Crittenden's son Thomas Crittenden to command Kentucky's pro-Union forces. The resolutions also included language that protected people's property including slaves. The measures passed overwhelmingly in both chambers leaving no doubt which side Kentucky supported. ${ }^{33}$

\footnotetext{
${ }^{33}$ See, House Journal, 11 September 1861, 2; 13 September 1861, 2; 15 September 1861, 2; 17 September
} 1861, 2; 19 September 1861, 3. See also, Senate Journal, 1861-63, 130-3. 


\section{CONCLUSION}

Initially, Kentuckians believed the political process would continue to work as it had for decades and somehow the secession crisis and war would once again be averted. Soon after Lincoln's election it became clear that the secession threat would become reality and that war would result. In the beginning of the secession crisis Kentuckians clung to the notion that their state could perform a balancing act between the warring sections appeasing both and somehow avoid armed conflict. In the end, because Confederate coercion became reality, the Commonwealth had no choice but to choose sides and involve itself in the bloody affair. Kentuckians chose to remain loyal to the Union due to their firm belief that the Union best protected their rights under the federal constitution including their right to hold property in persons.

Tracing the state's legislative actions from the state Constitutional Convention of 1849-50 through the secession crisis and into the first year of the Civil War it is clear why Kentucky chose to navigate its course inside the Union. Strong elements of Whig ideology persisted in the state throughout this crucial period and manifested itself in the actions of the legislature. From the State Constitutional Convention of 1849-1850 through the secession crisis and into the first year of the Civil War the state legislature's actions were consistent with Whig ideology. For a majority of Kentuckians, they expressed this view as maintaining their loyalty to the Union. The actions of the state's political actors during this period reflected the majority sentiment of the people of the 
Commonwealth of Kentucky that always espoused the view that their right to hold property in persons was best protected under the United States Constitution. The majority of Kentuckians also believed the election of a president was not sufficient to dissolve the Union. In the face of national crisis Kentuckians had always sought compromise first as the persistent secession threats from the Deep South slave states endured. After the election of Abraham Lincoln, Kentuckians sought a conciliatory approach to resolving the complex secession crisis. Consistent with the enduring Whig ideological influence that persisted in the state Kentucky's politicians sought compromise in an effort to appease both sections North and South to avoid sectional conflict but more important to maintain the Union. While the state's neutrality policy proved erroneous, it suggests the willingness of Kentuckians to attempt a compromise solution to the complex secession problem. While the Commonwealth of Kentucky of course stood to benefit from such a policy by protecting trade with each section and also avoiding direct involvement in the conflict Whig ideology was the prevailing force that influenced the state's political actors to adopt such a moderate course. Kentucky's key politicians Henry Clay and John J. Crittenden had always first sought compromise when faced with the threat of secession on the national political scene. In the end, Clay and Crittenden advocated maintaining the Union and crafted compromise measures that sought to appease both sections and averted conflict. In time, Kentucky's neutrality policy was not practical and events caused the state to choose sides in the sectional conflict. As a result the legislature chose to remain loyal to the Union. Upon examining the legislative actions of the state legislature in the period from 1849-1861 Kentuckians chose to 
navigate a course that was most consistent with their political history: compromise first, non-agitation and preservation of slavery, and allegiance to the Union.

During the secession crisis of 1860-61 the majority of Kentuckians remained resolute in their commitment to the Union. Despite Lincoln's election to the Presidency, South Carolina's willingness to secede, and the prospect for full scale armed conflict occurring within their home state, most Kentuckians were unwilling to forgo the Union.

Kentuckian's conception of the proper role of government influenced their action during the secession crisis. The majority of Kentuckians were unwilling to accept that their rights were best protected outside of the Union, in the new Confederacy, rather than under the federal constitution. During the secession crisis in $1860-61$, election results from three state elections and the Commonwealth's decision to remain in the Union prove that a majority of Kentuckians accepted the basic Whig ideology that advocated maintaining slavery and preserving the Union.

While geography contributed to the prevalence of slavery within each geographic section of the state, Whig ideology influenced most Kentuckians actions within each section of the Commonwealth. In the mountainous region of eastern Kentucky there were few slaves. This region was the so called Gibraltar of Whiggery and a strong proUnion sentiment prevailed there. By contrast, in the Jackson Purchase region in the far western part of the state, where large plantations existed, there were many slaveholders who held a strong pro-secession viewpoint. In the Bluegrass Region in the central part of the state, where many large scale slaveholders also existed, there had likewise existed a popular pro-secession sentiment. However, in this region many slaveholders decided the Union was the best protector of their property rights that included their constitutional 
right to own slaves. The pro-Union position taken by many slaveholders in the Bluegrass Region is a reflection of the strong Whig tradition that prevailed there. Although geography contributed to the significance of slavery within each geographic section of the state, the power of Whig ideology best explains the majority of Kentuckians' response and reactions to events such as, the $1849-50$ state constitutional convention, the 1854 Kansa-Nebraska Act, the Lecompton Controversy, and the secession crisis of 1860 61.

Whig ideology continued to influence Kentuckians response to events long after the Whig Party had ceased to exist in the Commonwealth. The basic Whig philosophy had dominated Kentucky politics from the beginning of the second party system in the 1830's until the Whig Party's demise in the mid 1850's. During the post Whig Party era in Kentucky many political parties emerged including the Americans or Know-Nothings, the Opposition, the Constitutional Union, and Union parties. In each of these parties elements of Whig ideals can be found. Even the Democrat Party that became the dominant political party in Kentucky post 1855 , had many former Whigs that joined the Party in the aftermath of the Whig Party collapse. Although these former Whigs were of the southern rights strain of the Whig Party, they joined the Democrats more due to their inability to support the Americans, rather than any strong feelings they had for the Democrats. During the events of 1860-61 many of the former Whig Democrats expressed their pro-Union views rooted in their Whig ideology. The fact that many former Whigs formed a significant part of the Democrat Party in Kentucky explains how the solid Democrat legislature elected in 1859, could have a pro-Union majority in 1861 . 
No one single factor can entirely explain Kentuckian's actions during the 1850's or during the secession crisis in 1860-61. Many factors contributed in varying degrees to shaping Kentuckian's responses to events during this time period. Economics, geography, culture, partisan politics all contributed to shaping Kentuckian's actions. The perceived practical significance slavery held for the state by a majority of its residents also contributed to influencing most Kentuckian's actions during the period from 18491861. However, the firm belief among a majority of Kentuckians that slavery should be preserved in the state does not account for the approach the state should take to ensure the continuation of the peculiar institution within the Commonwealth. During the secession crisis Kentuckian's expressed their pro-Union sentiment consistent with the Whig ideology that still prevailed in their state. In the end, Kentuckians remained committed to their belief that the right to own slaves was best protected inside of the Union under the federal constitution. While other factors may have influenced Kentuckians response to events during the 1850 's, Whig ideology served as the key factor that influenced Kentuckian's decision to remain loyal to the Union in the midst of the secession crisis. 


\section{REFERENCES}

\section{SECONDARY SOURCES}

\section{BOOKS}

Bakeless, John. Master of the Wilderness, Daniel Boone. New York: 1939.

Barre, W.L., ed. Speeches and Writings of Hon. Thomas F. Marshall. Cincinnati: 1858.

Berghe, Pierre van den. Race and Racism: A Comparative Perspective. New York: 1967.

Bibb, Henry. Narrative of the Life and Adventures of Henry Bibb, an American Slave. New York: The Author, 1849.

Brown, Kent Masterson, ed. The Civil War in Kentucky: Battle for the Bluegrass State. Mason City, Iowa: Savas Publishing Company, 2000.

Burnham, Walter Dean. Presidential Ballots 1836-1892. Baltimore: The John Hopkins Press, 1955.

Clark, Thomas. A History of Kentucky. New York: Prentice-Hall, 1937.

------. Kentucky: Land of Contrast. New York: Harper \& Row, 1968.

Clay, Cassius Marcellus. The Life of Cassius Marcellus Clay. Cincinnati: 1886.

Coleman, J. Winston. Slavery Times in Kentucky Chapel Hill: The University of North Carolina Press, 1940.

------. Stage-Coach Days in the Bluegrass. Louisville: 1935.

Collins, Lewis and Richard H., eds. Collins' Historical Sketches of Kentucky: History of Kentucky, Volume I. Louisville: John P, Morton \& Company Inc., 1924.

Connelly, William Elsey and E. Merton Coulter, eds. History of Kentucky, 5 vols. Chicago and New York: 1922.

Coulter, E. Merton. The Civil War and Readjustment in Kentucky. Chapel Hill: The University of North Carolina Press, 1926. 
Coward, Joan Wells. Kentucky in the New Republic: The Process of Constitution Making. Lexington: University Press of Kentucky, 1979.

Cuming, Fortescue. Sketches of a Tour to the Western Country. Pittsburgh: 1810

Darlington, William M. ed. Christopher Gist's Journals. Pittsburgh: 1893.

Davis, William C. Breckinridge: Statesman, Soldier, Symbol. Baton Rouge: Louisiana State University Press, 1974.

Dollar, Kent T., Larry H. Whiteaker, and W. Calvin Dickinson, eds. Sister States, Enemy States: The Civil War in Kentucky and Tennessee. Lexington: The University Press of Kentucky, 2009.

Eaton, Clement. Henry Clay and the Art of American Politics. Boston: Little, Brown, 1957.

Fairbank Calvin. Rev. Calvin Fairbank during Slavery Times: How He "Fought the Good Fight" to Prepare "The Way.” Chicago: R.R. McCabe, 1890.

Fedric, Francis. Slave Life in Virginia and Kentucky. London: 1863.

Fee, John G. Autibiography of John G. Fee. Chicago: 1891.

Fladeland, Betty. James Gillespie Birney: Slaveholder to Abolitionist New York: Greenwood Press, Publishers, Reprint ed. 1969.

Flint, Timothy. Recollections of the Last Ten Years. Boston: 1826.

Foner, Eric. Politics and Ideology in the Age of the Civil War. New York: Oxford University Press, 1980.

------. Reconstruction: America's Unfinished Revolution. New York: Harper \& Row Publishers, 1988.

Fordham, Elias P. Personal Narrative. Cleveland: 1906.

Freehling, William W. The Road to Disunion. Volume I. Secessionists at Bay, 17761854. New York: Oxford University Press, 1990.

Gara, Larry. The Liberty Line: The Legend of the Underground Railroad. Lexington: The University Press of Kentucky, 1961.

Genovese, Eugene D. Roll Jordan Roll: The World That Slaves Made. New York: 1972. 
------ The World the Slaveholders Made: Two Essays in Interpretation. New York: Pantheon Publishers, Inc. 1969.

Greeley, Horace. ed. The Writings of Cassius Marcellus Clay: Including Speeches and Addresses. New York: Harper \& Brothers, Publishers, No. 82 Cliff Street, 1848.

Griffler, Keith P. Frontline of Freedom: African Americans and the Forging of the Underground Railroad in the Ohio Valley. Lexington: The University Press of Kentucky, 2004.

Harrison, Lowell H. Lincoln of Kentucky. Lexington: The University Press of Kentucky, 2000.

-------. The Civil War in Kentucky. Lexington: The University Press of Kentucky, 1975.

------. The Anti-slavery Movement in Kentucky. Lexington: The University Press of Kentucky, 1978.

Harrison, Lowell H. and James C. Klotter, eds. A New History of Kentucky. Lexington: The University Press of Kentucky, 1977.

Harrold, Stanley. Abolitionists and the South, 1831-1861. Lexington: The University Press of Kentucky, 1995.

Henson, Josiah. Father Henson's Story of His Own Life. Boston: 1858.

Holt, Michael F. The Rise and Fall of the American Whig Party: Jacksonian Politics and the Onset of the Civil War. New York: Oxford University Press, 1999.

Hudson, J. Blaine. Fugitive Slaves and the Underground Railroad in the Kentucky Borderland. Jefferson, N.C.: McFarland \& Company, Inc., Publishers, 2003.

------.. Encyclopedia of the Underground Railroad. Jefferson, N.C.: McFarland \& Company, 2006.

Jenkins, William Sumner. Pro-slavery Thought in the Old South. Chapel Hill: University of North Carolina Press, 1935.

Johnston, J. Stoddard, ed. Memorial History of Louisville From its First Settlement to the Year 1896, 2 vols. Chicago: 1896.

Kirwan, Albert D. John J. Crittenden: The Struggle for the Union. Lexington: The University Press of Kentucky, 1962.

Littell, William and Jacob Swigert, eds. A Digest of the Statute Laws of Kentucky. Frankfort: 1822. 
Littell, William. The Statute Laws of Kentucky, 5 vols. Frankfort: 1809-1819.

Lucas, Marion B. A History of Blacks in Kentucky: Volume I, From Slavery to Segregation, 1760-1891. Frankfort: The Kentucky Historical Society, 1992.

McDougle, Ivan E. Slavery in Kentucky, 1792-1865. Lancaster: 1918.

McFarlan, Arthur C. Geology of Kentucky. Lexington: The University Press of Kentucky, 1943.

McPherson, James M. Ordeal by Fire: The Civil War and Reconstruction. New York: McGraw-Hill Companies, Inc., 2001.

Melish, John. Travels through the United States, 1806-1811, II. Philadelphia: 1815.

Ranck, George W. Boonesborough. Louisville, 1901.

Remini, Robert V. Henry Clay: Statesman for the Union. New York: W.W. Norton \& Company, 1991.

Rice, Otis K. Frontier Kentucky. Lexington: University Press of Kentucky, 1975.

Richardson, H. Edward. Cassius Marcellus Clay, Firebrand of Freedom. Lexington: The University Press of Kentucky, 1976.

Runyon, Randolph Paul. Delia Webster and the Underground Railroad. Lexington: The University Press of Kentucky, 1996.

Sears, Richard. The Kentucky Abolitionists in the Midst of Slavery 1854-1864: Exiles for Freedom. Lewiston: The Edwin Mellen Press, 1993.

Smiley, David L. The Lion of White Hall: The Life of Cassius Marcellus Clay. Madison: The University of Wisconsin Press, 1962.

Smith, Edward Conrad. The Borderland in the Civil War. New York: The Macmillan Company, 1927.

Speed, James. A Personality. Louisville: 1914.

Speed, Thomas. Union Cause in Kentucky. New York: G.P. Putnam’s Sons, 1907.

-------. The Wilderness Road. Louisville, 1886.

Tallant, Harold D. Evil Necessity: Slavery and Political Culture in Antebellum Kentucky. Lexington: University Press of Kentucky, 2003.

Townsend, William H. Lincoln and his Wife's Home Town. Indianapolis: 1929. 
Van Deusen, Glyndon G. The Life of Henry Clay. Boston: Little, Brown, 1937.

Weld, Theodore D. American Slavery As It Is: Testimony of a Thousand Witnesses New York: 1839.

Wiecek, William M. The Sources of Antislavery Constitutionalism in America, 17601848. Ithaca: Cornell University Press, 1977.

Woodson, Carter G. ed. Mind of the Negro as Reflected in Letters Written during the Crisis, 1800-1860. Washington, D.C.: 1926.

\section{CHAPTERS IN BOOKS}

Faust, Drew Gilpin. "Introduction: The Proslavery Argument in History." Drew Gilpin Faust. ed. The Ideology of Slavery: Proslavery Thought in the Antebellum South, 1830-1860. Baton Rouge: Louisiana State University Press, 1981.

Holt, Michael F. "The Mysterious Disappearance of the American Whig Party." Political Parties and American Political Development from the Age of Jackson to the Age of Lincoln. Edited by Michael F. Holt. Pp. 239-51. Baton Rouge: Louisiana State University Press, 1992.

Holt, Michael F. "The Politics of Impatience: The Origins of Know-Nothingism." Political Parties and American Political Development from the Age of Jackson to the Age of Lincloln. Edited by Michael F. Holt. Pp. 265-90.

Mackey, Thomas C. "Not a Pariah, but a Keystone: Kentucky and Secession," Kent T. Dollar, Larry H. Whiteaker, and W. Calvin Dickinson. eds. Sister States, Enemy States: The Civil War in Kentucky and Tennessee. Lexington: The University Press of Kentucky, 2009.

\section{ARTICLES}

Donald, David Herbert. “The Proslavery Argument Reconsidered.” Journal of Southern History 37 (February 1971): 6.

Dues, Michael T. "Governor Beriah Magoffin of Kentucky: Sincere Neutral or Secret Secessionist?" The Filson Club History Quarterly 40 (January 1966): 22-8.

Eaton, Clement. "Minutes and Resolutions of an Emancipation Meeting in Kentucky in 1849." Journal of Southern History 14 (November 1948): 541-45.

Gilliam, Will D., Jr. "Robert J. Breckinridge: Kentucky Unionist.” Register of the Kentucky Historical Society 69 (October 1971): 362-85. 
Gregory, James P., Jr. "The Question of Slavery in the Kentucky Constitutional Convention of 1849." Filson Club History Quarterly 23 (April 1949): 89-110.

Hamilton, Holman. "Kentucky's Lynn Boyd and the Dramatic Days of 1850." Register of the Kentucly Historical Society 55 (July 1957): 185-95.

Harrison, Lowell H. "Cassius Marcellus Clay and The True American." Filson Club History Quarterly 29 (October 1955): 320-323.

Harrison, Lowell H. "John C. Breckinridge: Nationalist, Confederate, Kentuckian." Filson Club History Quarterly 47 (April 1973): 125-43.

Harrold, Stanley. "Violence and Nonviolence in Kentucky Abolitionism." Journal of Southern History 57 (February 1991): 15-38.

Harrold, Stanley. "The Intersectional Relationship Between Cassius M. Clay and the Garrisonian Abolitionists." Civil War History 35 (June 1989): 101-119.

Howard, Victor B. "Robert J. Breckinridge and the Slavery Controversy in Kentucky in 1849." Filson Club History Quarterly 53 (October 1979): 331-49.

Kelly, Jack. "John J. Crittenden and the Constitutional Union Party." Filson Club History Quarterly 48 (July 1974): 265-76.

Knupfer, Peter B. "Henry Clay's Constitutional Unionism." Register of the Kentucky Historical Society 89 (Winter 1991): 32-60.

Lee, Jacob F. "Between Two Fires: Cassius M. Clay, Slavery and Antislavery in the Kentucky Borderlands." Ohio Valley History 6 (Fall 2006): 54-69.

Martin, Asa E. "The Anti-Slavery Movement in Kentucky Prior to 1850." Filson Club Publications no. 29 (1918): 39-49.

Mathias, Frank F. "Slavery, Solvent of Kentucky Politics." Register of the Kentucky Historical Society 70 (January 1972): 1-16.

Norton, Wesley. "Reaction in the Religious Press to the Campaign for Delegates to the Kentucky Constitutional Convention in 1849." Register of the Kentucky Historical Society 60 (April 1962): 162-83.

Shortridge, Wilson Porter. "Kentucky Neutrality in 1861." Mississippi Valley Historical Review 4 (March 1923): 283-301.

Steely, Will Frank. "William Shreve Bailey, Kentucky Abolitionist." Filson Club History Quarterly 31 (July 1957): 274-281.

Tapp, Hambleton. “The Slavery Controversy between Robert Wickliffe and Robert J. 
Breckinridge prior to the Civil War," Filson History Quarterly 19 (July 1945): 156-170.

Tapp, Hambleton. "Robert J. Breckinridge and the Year 1849." Filson Club History Quarterly 12 (July 1938). 126-50.

Troutman, Richard L. "The Emancipation of Slaves by Henry Clay." Journal of Negro History 40 (April 1955), 159-74.

Turner, Wallace B. "Abolitionism in Kentucky.” Register of Kentucky History Society 69 (October 1971): 319-38.

Turner, Wallace B. "Kentucky Slavery in the Last Antebellum Decade." Register of the Kentucky Historical Society 58 (October 1960): Register of the Kentucky Historical Society 58 (October 1960): 291-307.

Turner, Wallace B. "Kentucky State Politics in the Early 1850's." Register of the Kentucky Historical Society 56 (April 1958): 123-42.

Turner, Wallace B. “The Secession Movement in Kentucky." Register of the Kentucky Historical Society 66 (July 1968): 259-78.

\section{UNPUBLISHED WORKS}

Fields, Carl. “Making Kentucky's Third Constitution.” Ph. D. diss., University of Kentucky, 1951.

Menna, Larry K. "Embattled Conservatism: The Ideology of the Southern Whigs." Ph. D. diss., 1991.

Paine, Christopher M. “ 'Kentucky Will Be the Last to Give Up the Union': Kentucky Politics, 1844-1861.” Ph. D. diss., University of Kentucky, 1998.

Tallant, Harold Donald, Jr. "The Slavery Controversy in Kentucky, 1829-1859." Ph. D. diss., Duke University, 1986.

Troutman, Richard L. "The Social and Economic Structure of Kentucky Agriculture, 1850-1860." Ph. D. diss., University of Kentucky, 1958.

Volz, Harry A. "Party, State, and Nation: Kentucky and the Coming of the American Civil War.” Ph. D. diss., University of Virginia, 1982. 


\section{PRIMARY SOURCES}

\section{NEWSPAPERS}

Cincinnati Gazette

Frankfort Commonwealth

Frankfort Yeoman

Kentucky Reporter

Lexington Observer \& Reporter

Louisville Courier

Louisville Democrat

Louisville Examiner

Louisville Journal

Madison Courier

Maysville Eagle

National Intelligencer

New York Independent

Niles' Weekly Register

The Cultivator

The Lexington Atlas

The Presbyterian Herald

\section{MANUSRIPT COLLECTIONS}

John Jordan Crittenden Papers, microfilm from Library of Congress, Special Collections, Margaret I. King Library, University of Kentucky.

Cassius M. Clay Papers, Filson Club History Society, Louisville.

Correspondence of John G. Fee, Founders and Founding Collection, Berea College 
Archives.

Charles Lanman Papers, Filson Club History Society, Louisville.

Duncan Family Papers, Special Collection, Margaret I. King, University of Kentucky.

Orlando Brown Papers, Filson Club History Society, Louisville.

Henry Clay Letters, Special Collections, Margaret I. King Library, University of Kentucky.

Miscellaneous Papers, Kentucky Historical Society, Frankfort.

Wickliffe-Preston family Papers, Special Collections, Margaret I. King Library, University of Kentucky.

George D. Prentice Letters, microfilm, Special Collections, Margaret I. King Library, University of Kentucky.

\section{GOVERNMENT DOCUMENTS}

Kentucky House of Representatives. Journal.

Kentucky Senate. Journal.

Kentucky. Third Constitution. article 13, section 3, 1850.

Congressional Globe.

American Colonization Society Records. Library of Congress.

Greenup Circuit Court. Order Book 11. October term, 1829.

Kentucky. Acts 1849-1850.

Kentucky. Acts $1850-51$.

Kentucky. Revised Statutes, 1851 and 1852. Frankfort: Baldwin, 1852.

Legislative Records of Louisville, Kentucky. November 5, 1853. Microfilm Project 10, Reel 45. 235 vols. Louisville: University of Louisville.

Second Census of the United States, 1800.

Fifth Census of the United States, 1830.

Sixth Census of the United States, 1840. 
Seventh Census of the United States, 1850.

Eighth Census of the United States, 1860.

Guide to U.S. Elections.

Kentucky. Report of the Debates and proceedings of the Convention for the Revision of the Constitution of the State of Kentucky, 1849. Frankfort: A.G. Hodges, 1849.

Trustees Minute Book. Lexington, Kentucky. Microfilm 224. Lexington: University of Kentucky.

United States Census Reports, 1790-1860.

Will of Fielding L. Turner. Fayette County Court. Will Book P, 503-504. October 1, 1843. 


\section{CURRICULUM VITAE}

NAME: $\quad$ Curtis Lushawn Parmley

ADDRESS: 9401 Hurstbourne Crossings Drive

S. Hurstbourne Parkway

Louisville, KY 40299

DOB: $\quad$ Monticello, Kentucky- December 11, 1975

EDUCATION

\& TRAINING: $\quad$ B.A., Political Science

University of Louisville

2005-2008

HONORS SOCIETIES: $\quad$ Phi Alpha Theta, International Academic Honors Society for History, Member, 2010-2012

Golden Key, International Academic Honors Society, Member, 2010-2012

PROFESSIONAL SOCIETIES: Kentucky Historical Society, Student Member, 2011-2012

Filson Historical Society, Student Member, 2011-2012

American Historical Society, Student Member, 2011-2012 